\title{
The role of ultrasound in the fertility clinic
}

Citation for published version (APA):

Hamilton, C. J. C. M. (1986). The role of ultrasound in the fertility clinic. [Doctoral Thesis, Maastricht University]. Rijksuniversiteit Limburg. https://doi.org/10.26481/dis.19861107ch

Document status and date:

Published: 01/01/1986

DOI:

10.26481/dis.19861107ch

Document Version:

Publisher's PDF, also known as Version of record

\section{Please check the document version of this publication:}

- A submitted manuscript is the version of the article upon submission and before peer-review. There can be important differences between the submitted version and the official published version of record.

People interested in the research are advised to contact the author for the final version of the publication, or visit the DOI to the publisher's website.

- The final author version and the galley proof are versions of the publication after peer review.

- The final published version features the final layout of the paper including the volume, issue and page numbers.

Link to publication

\footnotetext{
General rights rights.

- You may freely distribute the URL identifying the publication in the public portal. please follow below link for the End User Agreement:

www.umlib.nl/taverne-license

Take down policy

If you believe that this document breaches copyright please contact us at:

repository@maastrichtuniversity.nl

providing details and we will investigate your claim.
}

Copyright and moral rights for the publications made accessible in the public portal are retained by the authors and/or other copyright owners and it is a condition of accessing publications that users recognise and abide by the legal requirements associated with these

- Users may download and print one copy of any publication from the public portal for the purpose of private study or research.

- You may not further distribute the material or use it for any profit-making activity or commercial gain

If the publication is distributed under the terms of Article $25 \mathrm{fa}$ of the Dutch Copyright Act, indicated by the "Taverne" license above, 
The role of ultrasound

in the fertility clinic 



\section{The role of ultrasound in the fertility clinic}

Proefschrift

ter verkrijging van de graad van doctor in de geneeskunde aan de Rijksuniversiteit Limburg te Maastricht, op gezag van de Rector Magnificus Prof. Dr. F.I.M. Bonke, volgens besluit van het College van Dekanen, in het openbaar te verdedigen in de aula van de universiteit op vrijdag 7 november 1986 des namiddags te vier uur

door

Carolus Johannes Cornelis Marie Hamilton

geboren te Nijmegen 
Promotor: $\quad$ Prof. Dr J. de Haan

Co-promotores: Dr J.L.H. Evers

Dr H.J. Hoogland

Referenten: Prof. Dr I.A. Brosens

Prof. Dr J.A. Flendrig 
aan mijn ouders,

aan Magda, Willem Jan en Karlien 
There can be no better indication of the moment of ovulation

than watching the rupture of the follicle, nor anything more dramatic.

Dr Patrick Steptoe, 1974 


\section{Contents}

9 Voorwoord

11 List of abbreviations

13. CHAPTER I

General introduction

1. Physiology of the menstrual cycle

2. Methods of ovulation detection and prediction

3. Normal follicle growth as detected by ultrasound

4. Clinical applications of ultrasonographic follicle measurements

5. Aims of the study

39 CHAPTER II

Ultrasound increases the prognostic value of the postcoital test

51 CHAPTER III

The reliability of ovulation prediction by a single ultrasonographic follicle measurement

61 CHAPTER IV

Follicle growth curves and hormonal patterns in patients with the luteinized unruptured follicle syndrome

77 CHAPTER V

Ovulatory disorders and inflammatory adnexal damage: a neglected cause of the failure of fertility microsurgery

83 CHAPTER VI

Ovulatory disturbances in patients with luteal insufficiency 
95 CHAPTER VII

General discussion

100 Summary

102 Samenvatting

105 Curriculum vitae 
Het in dit proefschrift beschreven onderzoek werd uitgevoerd binnen de Capaciteitsgroep Obstetrie en Gynaecologie van het Academisch Ziekenhuis te Maastricht.

Dat bij het schrijven van een proefschrift de hulp van anderen onontbeerlijk is, werd ook nu weer duidelijk. Van hen die een essentiële bijdrage hebben geleverd wil ik met name noemen:

De patiënten en proefpersonen, die zoveel geduld en uithoudingsvermogen aan de dag hebben gelegd en bereid waren, meestal buiten de kantooruren, aan het onderzoek mee te werken.

Prof. Dr Jelte de Haan, mijn promotor, die een belangrijk aandeel had in mijn opleiding tot vrouwenarts. Hij vormde een sterke stimulans tot het doen van onderzoek, maar liet mij bij de uitwerking ervan vrij.

Dr Henk Hoogland, die de inspirator was van het onderzoek. Met zijn originele ideeën kan nog menig onderzoek geëntameerd worden.

Dr Leo Wetzels, die mij tijdens de voorbereidingen van zijn eigen proefschrift heeft ingewijd in de echoscopische follikelmeting.

Prof. Dr I.A. Brosens, die tijdens mijn medische studie aan de Katholieke Universiteit te Leuven mijn interesse voor de gynaecologie in het algemeen, en de vruchtbaarheidsstoornissen in het bijzonder heeft gewekt. Het was een eer dat hij nu als referent van mijn proefschrift wilde fungeren.

Prof. Dr J.A. Flendrig, die het manuscript van kritische kanttekeningen en waardevolle adviezen voorzag.

Dr Jolande Land, die het manuscript nauwkeurig op grammaticale fouten en taalfouten corrigeerde.

De verpleegkundigen van de verloskamer, die te allen tijde bereid waren bloed af te nemen en in te vriezen.

De medewerkers van het klinisch chemisch laboratorium, in het bijzonder de heer Lucien Habets, die zorg droegen voor de hormoonbepalingen.

De heer Piet Zinken, die het computerprogramma schreef voor de opslag van gegevens en steeds terstond hulp bood indien ik aan het eind van mijn computerlatijn was.

Ir Arno Muytjens en Drs Frans Tan van de Capaciteitsgroep Medische Informatica en Statistiek, die het merendeel van de statistiek voor hun rekening namen.

De medewerkers van de Medische Fotografie, die de afdrukken maakten van de illustraties.

Mevr. Margot Brans Brabant-Schiffer, die de tekstverwerking van het manuscript 
verzorgde. Samen met mej. Liesbeth van der Poel verzorgde zij ook de verschillende versies die aan de tijdschriften werden aangeboden.

Dr Hans Evers, die in alle opzichten de grootste bijdrage aan het proefschrift heeft geleverd. Van zijn talenten heb ik dankbaar gebruik gemaakt. 


$\begin{array}{ll}\text { AID } & \text { artificial insemination with donor semen } \\ \text { AIH } & \text { artificial insemination with husband's semen } \\ \text { BBT } & \text { basal body temperature } \\ \text { CC } & \text { clomiphene citrate } \\ \text { E }_{2} & \text { 17- } \beta \text {-estradiol } \\ \text { EE } & \text { ethinylestradiol } \\ \text { FFR } & \text { failure of the follicle to rupture } \\ \text { FSH } & \text { follicle stimulating hormone } \\ \text { h } & \text { hour } \\ \text { hCG } & \text { human chorionic gonadotropin } \\ \text { hMG } & \text { human menopausal gonadotropin } \\ \text { HPF } & \text { high power field } \\ \text { IU } & \text { international units } \\ \text { IVF } & \text { in-vitro fertilization } \\ \text { l } & \text { liter } \\ \text { LH } & \text { luteinizing hormone } \\ \text { LHRH } & \text { luteinizing hormone releasing hormone } \\ \text { LI } & \text { luteal insufficiency } \\ \text { LUF } & \text { luteinized unruptured follicle } \\ \text { MHz } & \text { megaherz } \\ \text { mg } & \text { milligram } \\ \text { mm } & \text { millimeter } \\ \text { N } & \text { number of subjects } \\ \text { ng } & \text { nanogram (10-9 gram) } \\ \text { P } & \text { progesterone } \\ \text { PC } & \text { postcoital } \\ \text { PF } & \text { peritoneal fluid } \\ \text { PGs } & \text { prostaglandines } \\ \text { pg } & \text { picogram (10-12 gram) } \\ \text { PI } & \text { progesterone index } \\ \text { PID } & \text { pelvic inflammatory disease } \\ \text { RIA } & \text { radioimmunoassay } \\ \text { PCOD } & \text { polycystic ovarian disease } \\ \text { r } & \text { correlation coefficient } \\ \text { SD } & \text { standard deviation } \\ \text { TRADINVEST } & \text { traditional investigation } \\ \text { UOT } & \text { ultrasonographic ovulation time } \\ \text { USINVEST } & \text { ultrasound investigation } \\ & \end{array}$





\section{General introduction}

Ovulation is one of the central events in reproduction. Whereas in most mammals the female only accepts the male during estrus, the human female generally exhibits no peak of sexual activity around the time of ovulation. In most women ovulation occurs asymptomatically. Yet, for couples who want to achieve pregnancy, but also for those who want to avoid pregnancy, it is necessary to know when the fertile period occurs. Diagnostic (e.g. the postcoital (PC) test) and therapeutic (e.g. artificial insemination) procedures in the fertility clinic require exact timing of the immediate preovulatory period. Furthermore, studies of all kinds of cyclic changes in the menstrual cycle require timing relative to the moment of ovulation. Therefore a need exists for simple and reliable methods of detecting and predicting ovulation. At present, several methods of ovulation detection are available, both direct and indirect. An ideal method to predict ovulation is still lacking. In the present study the clinical role of ultrasound in both detecting and predicting ovulation will be investigated.

The importance of follicular growth and ovulation for reproduction was first emphasized by Regnerus de Graaf as early as 1672 . He considered the entire follicle to be the ovum. In $1827 \mathrm{Karl}$ Ernst von Baer described the ovum to be situated in the Graafian follicle (Aiman, 1984).

Because most of the methods of ovulation detection are based on cyclic changes in ovarian function we will first review some physiological aspects of the menstrual cycle. Many of the mechanisms involved in the menstrual cycle were studied in animal models, especially the rhesus monkey model. The mechanisms in the rhesus monkey, however, bear a lot of resemblance to those in the human female. Much of the literature reviewed below, therefore, will concern the human female or the rhesus monkey. Afterwards, we will discuss the different methods of ovulation detection with special attention to ultrasonographic follicle measurements. Finally the clinical applications of ultrasound in the fertility clinic, as described in literature, will be reviewed.

\section{Physiology of the menstrual cycle}

\subsection{Follicle growth}

During early embryonic life the female gonads are colonized with germ cells (oogonia). Between the second and seventh month of intrauterine life oogenesis takes 


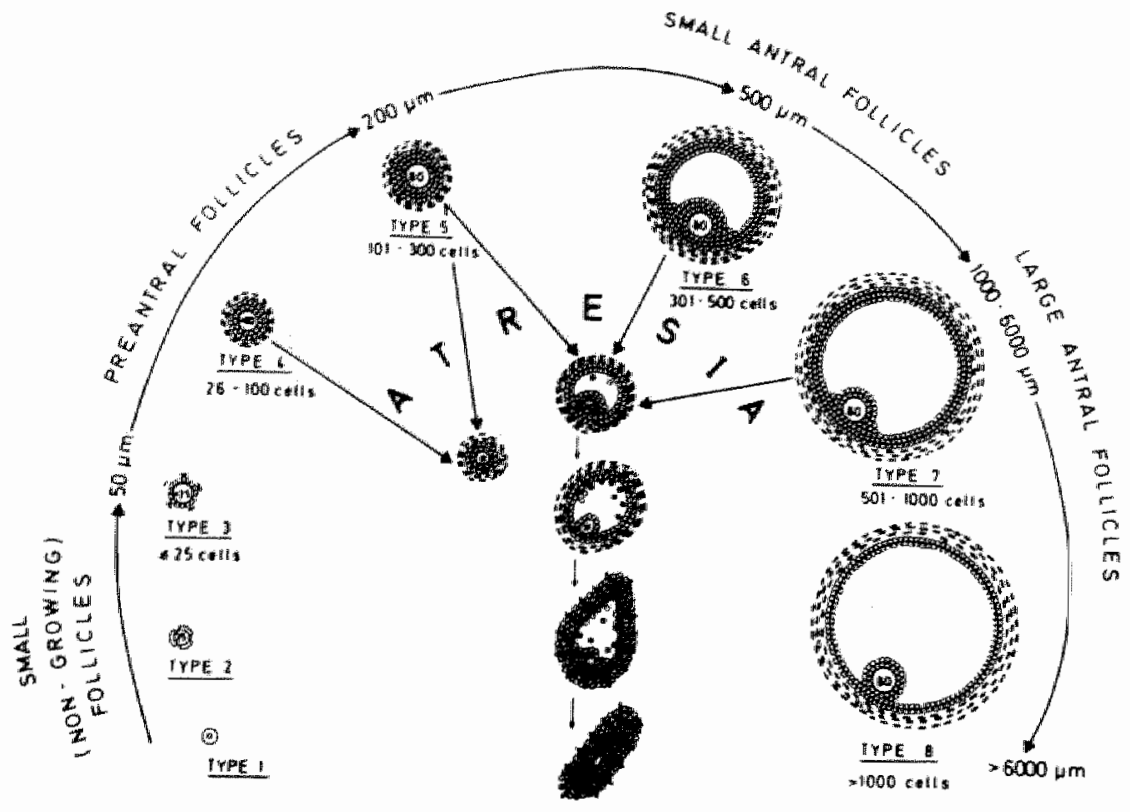

Figure I.I

Classification of follicles in the human ovary (Peters et al., 1978) (with permission).

place. In this period groups of oogonia start their first meiotic division and become oocytes. The oocytes stay in the diplotene stage of the meiotic division for an important part of their life. The development of cohorts of oocytes into cohorts of follicles, is called folliculogenesis. This is a continous process that starts during embryonic life and lasts until the menopause.

According to the stage of development four groups of follicles can be distinguished: primordial follicles, preantral follicles, antral follicles and preovulatory follicles (Peters and McNatty, 1980). Another, more detailed classification has been introduced, based on the size of the oocyte, the size of the follicle as defined by the number of granulosa cells, and on the morphology of the follicle (Figure I.1) (Peters et al., 1978). The time needed for a primordial follicle to reach the preovulatory stage is about 85 days (Gougeon, 1982). The last period, in which an antral follicle develops into a preovulatory follicle, takes about 14 days (Hodgen, 1982). Apart form the oocyte, follicles consist of granulosa cells and a basement membrane, which is surrounded by the theca layer. As soon as the theca becomes thicker, two layers can be distinguished: a theca interna, which is highly vascularized and a theca externa, which has less vascularization. With the accumulation of fluid in the follicular cavity (antrum) the cumulus oophorus, which contains the oocyte, becomes accentuated. The oocyte is surrounded by the zona pellucida. The granullosa cells lying immediately around the zona form the corona radiata. 
Every moment during reproductive life new follicles are recruited to start their development. This process is not interrupted by pregnancy or other periods of (induced) anovulation. During each menstrual cycle reduction takes place of the recruited number of potentially ovulatory follicles to a number characteristic of the species (McNatty, 1982). This is called selection of the dominant follicle(s) (Hogden, 1982). During the presence of a dominant follicle other developing (pre)antral follicles become atretric before they reach the preovulatory stage.

\subsection{Hormonal control of follicle growth}

Normal folliculogenesis presumes an intact hypothalamic-pituitary-ovarian axis. Intermittent release of luteinizing hormone releasing hormone (LHRH) from the nucleus arcuatus in the hypothalamus is required to permit normal stimulation of the pituitary gland (Knobil, 1980). The pulsatile pattern of LHRH release gives rise to a similar pattern in gonadotropin release (Yen et al., 1972), thus governing folliculogenesis and ovulation. The endocrinology of the menstrual cycle has been reviewed comprehensively by Fritz and Speroff (1982).

Approaching maturity, the preovulatory follicle produces increasing amounts of estrogens (Baird and Fraser, 1975). Primarily through negative and positive feedback mechanisms of $17-\beta$-estradiol $\left(E_{2}\right)$ the dominant follicle assumes control of its own destiny. $E_{2}$ levels rise rapidly during the follicular phase and surge to a peak level 24-72 hours prior to ovulation. Sustained threshold concentrations of $E_{2}$ stimulate the luteinizing hormone $(\mathrm{LH})$ surge (Young and Jaffe, 1976; Hoff et al., 1983) (Figure I.2). The first increase in plasma progesterone (P) level can be detected 24 to 48 hours before ovulation (DiZerega et al., 1980; Fleming and Coutts, 1982). Administration of the $P$ antagonist RU 486 suppresses in the human female the occurrence of the LH surge (Shoupe et al., 1986). Therefore the P rise, too, seems to play an important role in the induction of the combined midcycle surge of $\mathrm{LH}$ and follicle stimulating hormone (FSH). LH promotes luteinization of the granulosa cells, which results in a further increase in the production of $P$.

The LH surge, which starts 32-40 hours prior to follicle rupture, initiates in vitro the resumption of meiosis in the oocyte of the rat and luteinization of granulosa cells (Tsafriri et al., 1972). A decrease in the levels of substances like oocyte maturation inhibitor and luteinization inhibitor seems to be involved (Channing, 1985).

\subsection{Ovulation}

In spite of intensive research there is no general agreement about the exact mechanism underlying follicle rupture. The site of the rupture can usually be identified by the appearance of a translucent area on the surface of the follicle. When the wall ruptures, the cumulus mass, containing the oocyte, is released together with a rather 


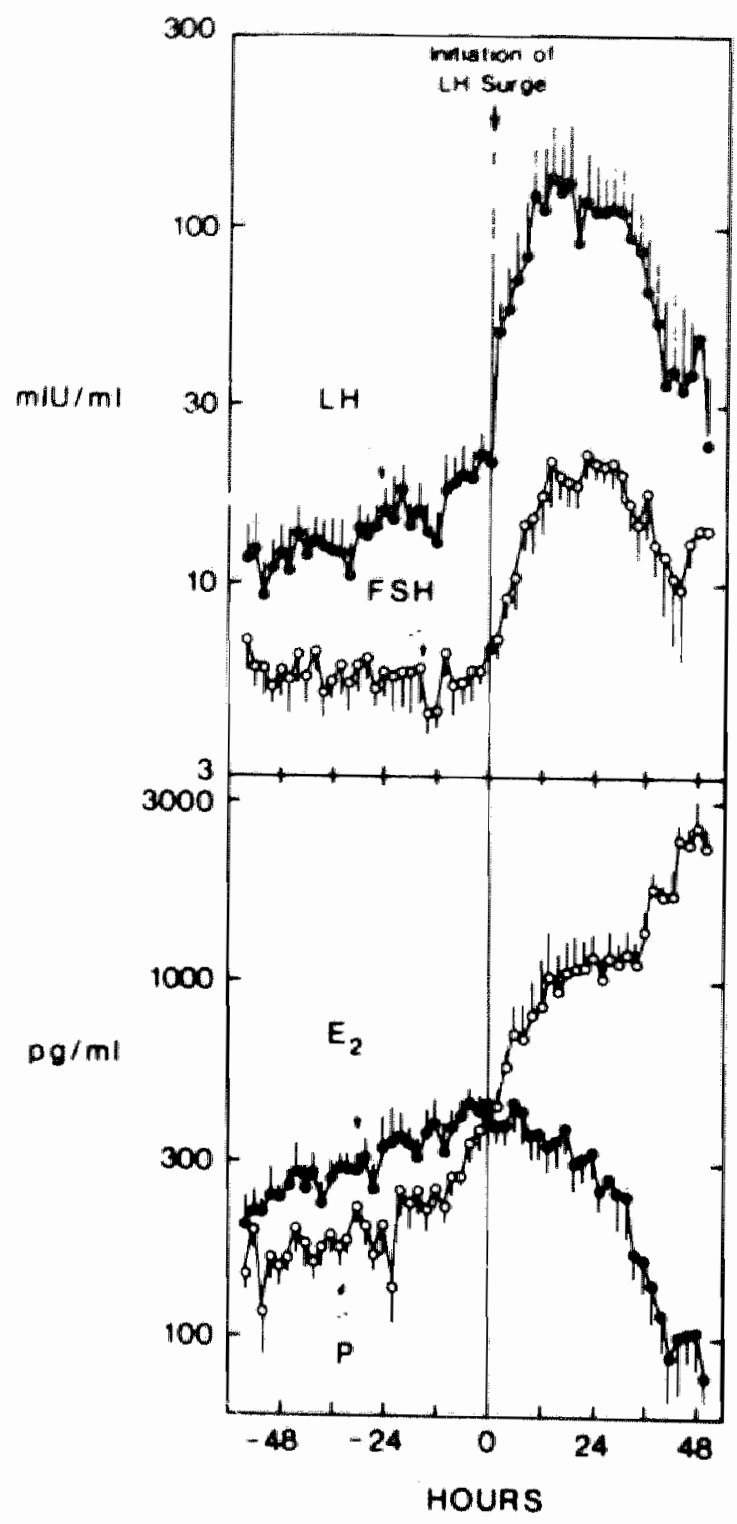

Figure 1.2

Changes in serum levels of $L H, F S H, E_{2}$ and $P$ measured every 2 hours for 5 days at midcycle in seven studies. The dota were centered at the initiation of the gonadotropin surge (Hoff et al, 1983) (with permission).

viscous follicular fluid. Because follicular fluid contains large amounts of steroids, after ovulation the steroid content of the peritoneal fluid increases considerably (Maathuis et al., 1978; Bouckaert, 1984). 
One of the most accepted theories for follicle rupture is that $\mathrm{LH}$, acting by stimulation of cyclic adenosine monophosphate (CAMP) activity, may enhance the activity of proteolytic enzymes, such as collagenase and plasmin, which results in digestion of collagen in the follicular wall (Espey, 1974; Beers, 1975).

Prostaglandins (PGs) of the $\mathrm{E}$ and $\mathrm{F}$ series appear to be involved also. In the rat the concentrations are at their maximum around ovulation (Lemaire et al., 1975). Inhibition of $P G$ synthesis (by Indomethacin) blocks follicle rupture in the rabbit without affecting the other LH induced processes of luteinization and oocyte maturation (Kobayashi et al., 1981). The midcycle FSH release has a stimulatory action upon plasminogen activator activity and upon the cumulus expansion. Furthermore it is a prerequisite for normal luteinization.

The rising $\mathrm{P}$ terminates the $\mathrm{LH}$ surge by a negative feedback mechanism (Helmond et al., 1980).

$P$ has an important role in the regulation of new follicular growth (Hodgen, 1982). Selective catheterisation of ovarian veins revealed that ovulation takes place contralateral to the side with the highest ovarian vein $P$ concentration (Hodgen, 1982). Furthermore, exogenous $\mathrm{P}$ inhibits follicle growth. Thus, $\mathrm{P}$ may regulate follicle growth both spatially and timely.

\subsection{The corpus luteum}

After rupture of the follicle the granulosa layer increases in size and becomes convoluted. Capillaries penetrate the granulosa layer, reach the antrum and fill it with blood. Increasing amounts of $P$ are produced. Seven days later vascularization reaches its maximum and is associated with a peak in plasma $P$ and $E_{2}$ levels. The granulosa cells and to a less extent the surrounding theca cells transform to lutein cells. These cells produce increasing amounts of $\mathbb{P}$.

Based on the changes in the appearance of the corpus luteum observed at light microscopy Corner (1956) introduced a histologic dating.

The corpus luteum remains dependent on the pituitary gland, which however, exhibits a slower pulsatile gonadotropin release in the luteal phase than in the follicular phase.

P levels decline gradually, unless the corpus luteum is rescued by human chorionic gonadotropin (hCG) produced in early pregnancy. The mechanism of luteolysis is not yet completely understood, but PGs seem to play an important role (Sotrel et al., 1981). Estrogens produced by the corpus luteum itself may be involved too (Karsch and Sutton, 1976). 


\section{Methods of ovulation detection and prediction}

\subsection{Calendar method}

Marion Sims was one of the first to time the fertile period of women correctly (1866). Yet it was only in 1930 that Ogino noted that ovulation usually takes place 12 to 16 days before the onset of menstruation. In 1933 Knaus confirmed this observation. Their finding resulted in the calendar method used for natural family planning. Mclntosh et al. (1980) showed that the prediction of the day of the LH peak improved when the variability in cycle length, assessed on the basis of the previous 6 menstrual cycles, was smaller. The greatest drawback of the calender calculation is that it depends on a prediction of what is likely to occur and not of what is actually taking place (Bonnar, 1983).

\subsection{Basal body temperature}

The most frequently used test in the last 50 years is the basal body temperature (BBT) chart. A rise in the BBT during the menstrual cycle was first recognised by Squire in 1868 (Aiman, 1984). Van de Velde in 1905 suggested that the temperature rise could be related to the moment of ovulation. But evidence for this theory was only obtained in the $1930 \mathrm{~s}$, when the shift in temperature was related to changes in the endometrium, the cervix and the vagina. In the luteal phase the BBT is approximately $0.4{ }^{\circ} \mathrm{C}$ higher than during the follicular phase due to the thermogenic effect of P. Recently however, the inaccuracy of the BBT has been demonstrated: $20-35 \%$ of ovulatory women appeared to have a monophasic BBT chart (Moghissi, 1976; Baumann, 1981). Furthermore the time relationship between temperature shift and the moment of ovulation shows a considerable variation (Wetzels et al., 1982). The interpretation of a BBT varies between different observers and even in the same observer at different occasions (Lenton et al., 1977).

The advantage of the BBT is that it can easily be applied by the woman herself. Furthermore, it can be of some help in ovulation induction and artificial insemination. A prolonged hyperthermic plateau is suggestive of pregnancy and if it is noticed the administration of ovulation inducing agents in early pregnancy can be prevented.

\subsection{Endometrial biopsy}

In the beginning of this century Schröder (1913) revealed the parallelism of the ovarian and uterine cycles, and introduced the cycle theory. Under influence of estrogens and $\mathrm{P}$ the histological appearance of the endometrial changes. Based on this 
knowledge both curettage on the first day of menstruation and endometrial biopsy during the luteal phase have been used to confirm ovulation. In 1950 Noyes and coworkers gave a detailed description of the histological changes in the endometrium during the menstrual cycle, which allows a histological dating of the endometrium. As a method of ovulation detection the (invasive) endometrial biopsy has been superseded by plasma radioimmunoassays (RIA's). For the detection of luteal insufficiency $(\mathrm{LI})$ the endometrial biopsy is still used by some clinicians.

\subsection{Vaginal cytology}

The hormonal status can also be delineated from cytologic examination of the vaginal epithelium. Under the influence of estrogens and $\mathrm{P}$ the epithelial cells change. This is reflected in an altered karyo-pycnotic index, and in changes in other cell characteristics (Riley et al., 1955). The predictive value of vaginal cytology is only limited.

\subsection{Cervix and cervical mucus}

Smith reported in 1855 that a woman is most fertile when the cervical mucus is most fluid (Aiman, 1984). A decade later Sims (1866) described the penetration of sperm in the cervical mucus, and related the result of the PC test to the prognosis of fertility. During the menstrual cycle there are quantitative and qualitative alterations in the cervical mucus as well as variations in the diameter of the cervical os (Billings et al., 1972). As a result of the stimulating influence of estrogens before ovulation, the mucus becomes profuse, thin, clear and acellular; the external os widens (Insler et al., 1972). When dried on a slide mucus forms a distinct fern pattern.

Abundant cervical mucus is, therefore, a sign of imminent ovulation. Immediately after ovulation, under the influence of $\mathrm{P}$ the mucus becomes sticky.

High serum estrogen levels, however, are also seen in patients with a polycystic ovarian disease (PCOD) or a persistent follicle. These conditions are also associated with abundant cervical mucus. Due to these facts and because of the inconsistent changes in cervical mucus, this parameter is of restricted value for the prediction of ovulation (Bonnar, 1983).

\subsection{Mittelschmerz}

Some women notice a low abdominal pain near the time of ovulation. O'Herlihy et al. (1980a) investigated the occurrence of Mittelschmerz in 96 ovulating women, using ultrasound and serum LH levels. He found Mittelschmerz to occur in $35 \%$ of the women and to be a preovulatory phenomenon. In almost $80 \%$ the pain was localized on the side of the developing follicle. 
Wetzels (1983) found an incidence of $31.4 \%$. In the majority of women Mittelschmerz was a preovulatory phenomenon. In the minority it coincided with the moment of ovulation and in rare cases it occurred after ovulation. He concluded that Mittelschmerz is not reliable for ovulation detection.

\subsection{Hormone determinations}

In the early fifties quantitative measurements of hormones became available (Brown, 1955), which extended the knowledge of the menstrual cycle considerably. The introduction of the more accurate RIA's for gonadotropins, steroids and many other hormones in the early seventies has further enhanced our understanding of the physiology and pathophysiology of human reproduction (Ross et al., 1970). The determination of the serum P level is an easy method to prove luteinization.

Because of the fixed time relationship between certain hormone changes and ovulation, ovulation prediction by RIA's is currently the most reliable method available (WHO, 1980). Especially the first rise of the $\mathrm{LH}$ surge has been proven to be of high value in this respect (Testart and Frydman, 1982). But also the increase in $E_{2}$ levels indicate that ovulation is imminent.

\subsection{Surgical methods}

The only way to relate indirect methods of ovulation detection precisely to the moment of ovulation is direct visualization of the rupture of the follicle. Before the introduction of ultrasound surgical methods were the only ones available. In 1951 Doyle was the first to describe the observation of a follicle rupture by means of culdotomy. Several years later Steptoe used the laparoscope for this purpose (1967). After ovulation a stigma can be visualized on the surface of the ovary (Vanrell et al., 1982; Portuondo et al., 1983). Theoretically, an ovum can be entrapped in the follicle, even in the presence of an ovulation stigma (Stanger and Yovich, 1984). Surgical methods of ovulation detection, however, are too invasive for application in a standard fertility investigation. Yet, several authors advise to time the laparoscopy, performed in a later stage of the fertility workup, in the early luteal phase of the cycle to look for the presence of an ovulation stigma (Koninckx et al., 1978; Marik and Hulka, 1978).

\subsection{Peritoneal fluid}

The release of the follicular fluid at the time of ovulation is associated with an increase in the steroid hormone concentrations in the peritoneal fluid (PF). High steroid hormone concentrations in the $\mathrm{PF}$ in the early luteal phase may therefore be suggestive of ovulation to have taken place (Maathuis et al., 1978; Bouckaert, 1984). 


\subsection{Ultrasound}

A recent advancement in evaluating ovarian function is the ultrasonographic visualization of the growing follicle. The procedure is noninvasive and can be repeated several times in the same subject, allowing ovulation detection.

By means of diagnostic ultrasound the Graafian follicle was first visualized in 1972 by Kratochwil and coworkers. Equipment with much higher resolution enabled Hackelöer et al. in 1977 to survey the follicular growth in a patient treated with gonadotropins. A new method of ovulation detection was born. Its reliability with respect to hormone parameters was studied by Wetzels and Hoogland (1982). In contrast to the $\mathrm{P}$ dependent methods of ovulation detection, like the BBT chart and the endometrial biopsy, ultrasound provides direct information on the cyclic changes in the ovaries.

\section{Normal follicle growth as detected by ultrasound}

During the early follicular phase the ovaries can be recognized ultrasonographically as oval, relatively homogenous structures, with small black areas not yet persistently demonstrable during consecutive days. About one week before ovulation the Graafian follicle can be identified as a well-defined echofree (transsonic) area (Hackelöer and Robinson, 1978; Hackelöer et al., 1979; Kerin et al., 1981; Renaud et al., 1980). If transabdominal probes are applied a full bladlder is necessary to obtain adequate visualization of the ovaries. Ultrasonographic follicle measurements were first performed by applying a compound B scanner. Today real time sector scanners are more generally used. The transabdominal probes have a frequency of 3.5 or $5 \mathrm{Mega-}$ herz $(\mathrm{MHz})$. If transvaginal probes are applied, even higher frequencies, with a better resolution, can be used.

Follicles, which are smaller than $14 \mathrm{~mm}$, continously arise and disappear. If a follicle becomes $14 \mathrm{~mm}$ or larger, it will develop into a dominant follicle. During the last 5 or 6 days before ovulation the dominant follicle exhibits linear growth (Hackelöer et al., 1979; Kerin et al., 1981). Renaud and coworkers (1980) found an accelerated growth shortly before ovulation. In conception cycles Zegers-Hochschild and coworkers (1984), on the other hand, observed a flattening of the curve.

The preovulatory sizes of the follicles described in literature differ considerably, ranging from a mean of $12.8 \mathrm{~mm}$ in the population of Ylöstalo et al. (1979) to a mean of $27 \mathrm{~mm}$ in the investigation of Renaud and coworkers (1980). More recent publications give less varying figures of the mean preovulatory follicle size and report population means of about $22 \mathrm{~mm}$ (Wetzels, 1983). Growth rates are described ranging between 1 and $4 \mathrm{~mm}$ per day. The large differences in mean preovulatory follicle diameter observed by different investigators can partly be explained by diffe- 
rent measuring procedures, and by differences in the setting of the ultrasound equipment. The interindividual variation in a population can vary considerably too, which expresses a wide biologic variation. Wetzels (1983) found a range of maximum preovulatory follicle diameters between $17-36 \mathrm{~mm}$.

Most investigators now use a standard technique of follicular measurement, calculating the mean diameter derived from three perpendicular diameters.

To assess the reliability of ultrasonographic follicle measurements both in vivo and in vitro experiments have been performed. O'Herlihy et al. (1980b) and Kerin et al. (1981) found a linear correlation between the volume of the follicles measured by ultrasound and the volume measured after laparoscopic follicle aspiration. Wetzels (1983) performed a number of in vitro experiments and he found that in more than $80 \%$ of ultrasound measurements of the volume of balloons, immersed in water, the deviation was less than $15 \%$ from the actual volume. The relative error of the mean diameter could be calculated to be as low as $2.33 \pm 2.26 \%$ (mean \pm standard deviation (SD)).

Even more important than good ultrasound equipment is the experience of the observer. One has to be able to differentiate the Graafian follicle from other cystic structures within the ovary like corpus luteum cysts and from cross sections through bloodvessels, the intestines, free fluid in the pouch of Douglas or hydatidiform cysts. The interobserver and intraobserver variation were assessed by Eissa and coworkers (1985). The intraobserver and interobserver SDs were $0.6 \mathrm{~mm}$ and $1.2 \mathrm{~mm}$, respectively. The pooled SD for both variables was $1.2 \mathrm{~mm}$, which gives $95 \%$ confidence limits of $\pm 2.4 \mathrm{~mm}$ for any measurement.

Ovulation is characterized by a complete disappearance of the transsonic area or by a sharp reduction in its size. Sometimes the follicle keeps the same size, but gets filled in with echodense structures. Most probably this is due to the cumulation of haemorrhagic fluid into the follicle. An additional sign of ovulation is the appearance of free fluid in the pouch of Douglas. Direct ultrasonographic observation of the ovulatory mechanism has revealed that emptying of the follicle takes place in only a few minutes to half an hour at most (DeCrespigny et al., 1981a).

The corpus luteum is either undistinguishable or remains visible as a vague transsonity surrounded by an echodense ring. After a few days a cystic corpus luteum may be formed, which disappears at the end of non-conception cycles, or may persist in case of pregnancy. Some authors consider the existence of a cystic corpus Iuteum as a prognostic favourable sign with respect to the occurrence of pregnancy (Hackelöer, 1984a).

Several investigators compared the ultrasound findings in the normal menstrual cycle with hormonal parameters (Hackelöer et al., 1979; Freundl et al., 1981; Wetzels and Hoogland, 1982). They concluded that ultrasound is a reliable method of ovulation detection. The ultrasonographic ovulation time can serve as a new reference point in the menstrual cycle. Wetzels and coworkers (1982) found that the temperature rise on the BBT chart can show a deviation of upto 5 days with respect to the ultrasonographically determined moment of ovulation. The BBT chart can only detect the moment of ovulation retrospectively. 
Although some authors warned against the exposure of the ripening oocyte within the Graafian follicle to ultrasound beams (Testart et all, 1982), until now nobody has demonstrated any harmful effect of diagnostic ultrasound to the many thousands of children, born after ultrasonographically monitored conception cycles.

\section{Clinical applications of ultrasonographic follicle measurements}

Due to its ability to display follicle growth and ovulation in a noninvasive way, ultrasound has become a useful instrument in infertility management.

Especially the following three applications of ultrasound in the fertility clinic are important:

- Ovulation prediction,

- Monitoring ovulation induction,

- The detection of disturbances of follicle growth and ovulation.

Each topic will be discussed in more detail.

\subsection{Ovulation prediction}

Soon after the introduction of ultrasound as a method of ovulation detection the expectations about the ovulation predictive value of ultrasound were high (Bryce et al., 1982). Gradually it became apparent, that a wide range in maximum mean preovulatory follicle diameters existed. Although this might preclude accurate ovulation prediction, no large study is available in literature about the predictive value of ultrasonographic measured follicle size with regard to the time of ovulation. Other ultrasonographic prediction signs were described, as for instance the appearance of an echodense structure on the innerside of the follicular wall (Hackeloer and Robinson, 1978). According to Bomsel-Helmreich and coworkers (1981) this structure represents the cumulus oophorus. Hackelöer and Robinson (1978) observed this structure in $80 \%$ of the cycles. Kerin and coworkers (1981) and Wetzels (1983), on the other hand, found it only in $23 \%$ and $15 \%$ of the cycles, respectively. Wetzels (1983) found the so called cumulus even 5 days before ovulation, whereas Hackelöer and Robinson (1978) stated that it becomes visible only 24 hours preovulatorily. Mendelson and coworkers (1985) found a cumulus in $28 \%$ of women who conceived and in only $3 \%$ of women who failed to conceive. The presence of a cumulus, according to these authors, seems to be of prognostic value. According to the same authors the appearance of "low-level intrafollicular echogenicity" may be a prognostic indicator of fertility also. Other investigators described the appearance of a line of decreased reflectivity around the follicle, caused by advanced sepa- 

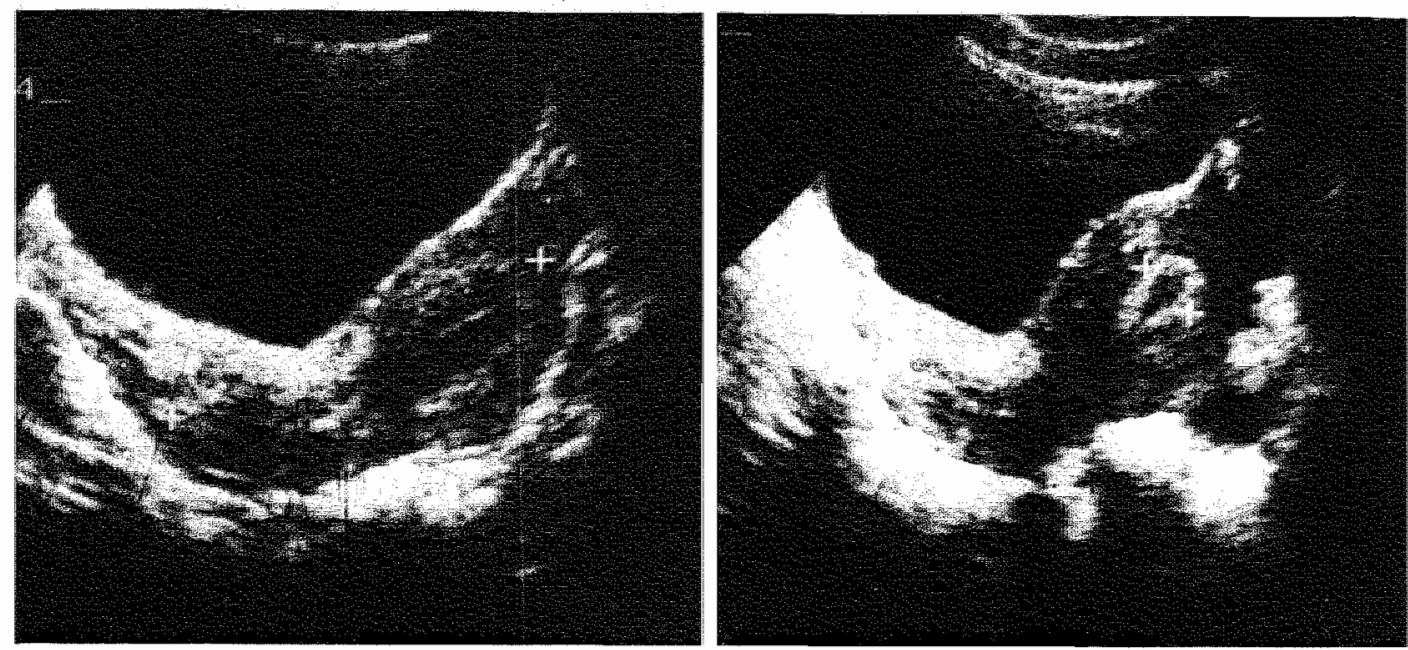

Figure 1.3

Longitudinal scans of the werus showing the ultrasonographic appearance of the endometrium in the proliferative phase (hefo) and in the midluteal phase (right).

ration of the granulosacell layer and producing a crenation pattern within the follicle, as a sign of imminent ovulation (Picker et al., 1983).

Also changes in the ultrasonographic aspect of the endometrium have been used in predictive sense. Endometrium in the proliferative phase has the aspect of a thin line, whereas endometrium in the secretory phase has the aspect of a thick echogenic layer (Sakamoto and Nakano, 1982) (Figure I.3). Hackelöer (1984b) studied the changes in the endometrium and correlated these with the growth of the follicle and with hormonal parameters. He classified the ultrasound picture of the endometrium of the proliferative phase in six categories. From these categories he tried to predict the moment of ovulation. Immediately after ovulation a ring phenomenon was observed in the sagittal and cross sections of the uterus. This ring sign was never encountered in anovulatory cycles. However, the interpretation of most of these ultrasonographic signs is still arbitrary. A need exists for standardization. Also the sensitivity, specificity and predictive value of these parameters need to be determined. For the time being ultrasound has not surpassed the detection of the LH peak by frequent blood sampling, as the most reliable method of ovulation prediction, although this last method is more expensive and inconvenient. Although ultrasound is inadequate in predicting the moment of ovulation accurately, the presence of a dominant follicle is an indicator of imminent ovulation. This qualification can be useful in the infertility treatment, for instance to time artificial inseminations in the direct preovulatory period. By performing serial ultrasound measurements until the follicle has ruptured the moment of ovulation can accurately be determined. If inseminations are repeated at constant intervals until ovulation is observed, timing of 
inseminations will be optimal. Rönnberg and coworkers described in 1978 the successful application of ultrasound in timing the moment of insemination. Kerin (1979) and Marinho and coworkers (1982) doubled the pregnancy rate of artificial donor insemination per cycle using ultrasound in comparison with the use of the BBT chart.

In order to obviate the inherent inaccuracy of ovulation prediction due to the wide range in preovulatory follicle diameters, Wetzels (1983) administered hCG and inseminated 36 hours later. He tried to individualize the treatment by using the data from previous cycles of the same patient. HCG was administered on the day that a mean follicle diameter was found which corresponded with the diameter found 1 or 2 days before the $\mathrm{LH}$ peak in a previous cycle. By this procedure inseminations were timed closer to the moment of ovulation than in a control group without $h \mathrm{CG}$. He did not report whether this method improved the pregnancy rate. But, if pregnancy rates are comparable, the fact, that less inseminations are needed per cycle, is an advantage. In case of limited amounts of semen (Hodgkin disease of the husband, artificial insemination with donorsemen etc.) the quantity can be used more efficiently.

\subsection{Monitoring ovulation induction}

The clinical availability of ovulation inducing agents as clomiphene-citrate (CC), gonadotropins and LHRH, has substantially improved the prognosis of the fertility in patients with anovulation.

By its ability to observe the number and size of the follicles directly, monitoring ovulation induction is one of the most important applications of ultrasound. As stated earlier, ultrasonic ovulation detection was first performed in a patient treated with gonadotropins. Pregnancy only occurs if hCG is administered when the dominant follicle has a mean diameter of more than $15 \mathrm{~mm}$ (Seibel et al., 1981). Administration of hCG in an earlier stage caused a short luteal phase (Seibel et al., 1981). Most authors suggest to administer hCG when the diameter is between 18 and $22 \mathrm{~mm}$. The moment of hCG administration can exactly be timed according to the follicle diameter. This results in a higher ovulation rate and increases the chances of pregnancy (Sallam et al., 1982).

Ovulation stimulants, however, can also cause serious complications. A distinction should be made between the occurrence of multiple pregnancy and the occurrence of the hyperstimulation syndrome. In this syndrome hCG leads to a considerable increase in size of the ovaries (Figure I.4), associated with haemodynamic disturbances, acute abdominal pain and ascites. To reduce the chance of complications, ovulation induction is usually monitored by measuring the estrogen levels either in urine or in blood. Furthermore inspection of the cervical mucus qualities and palpation of the size of the ovaries may be useful in this context. The estrogen level in blood or urine depends on the number of dominant follicles. In stimulated cycles estrogen 


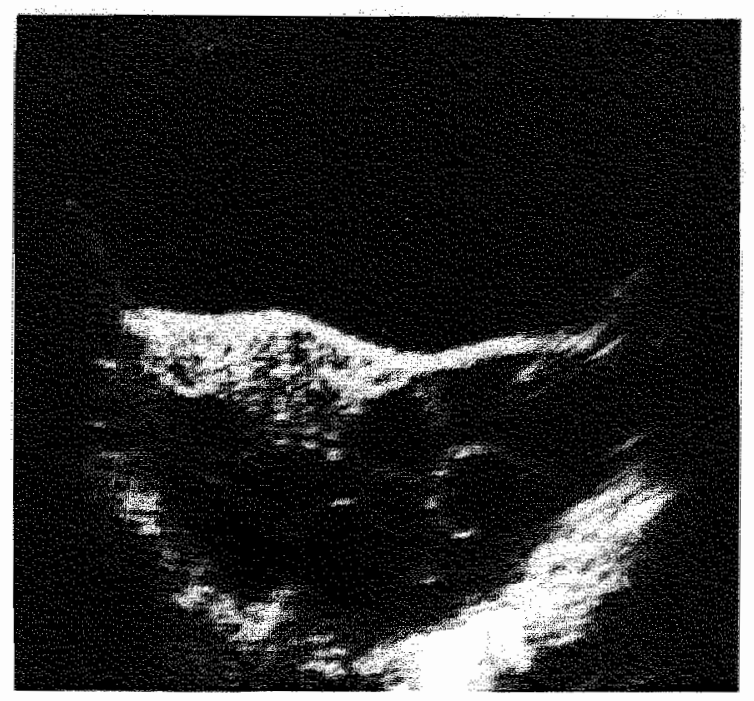

Figure 1.4

Transverse scan showing hyperstimulated ovaries.

levels alone do not give sufficient information about the maturity of the follicles. The advantage of ultrasound in monitoring ovulation induction is the possibility to withhold hCG if hyperstimulation can be expected and to dissuade a patient to have intercourse if impending superovulation is diagnosed.

In some patients no adequate follicle growth occurs, in spite of high estrogen concentrations. To wait with the administration of hCG until the largest follicle has reached a preovulatory size would inevitably lead to severe hyperstimulation in these patients. Therefore, the addition of ultrasound to hormone determinations provides additional safety in the treatment of patients with ovulatory disturbances. On the other hand, in some patients monitoring follicle growth by ultrasound can result in the continuation of gonadotropin-induction, whereas, monitoring by hormonal parameters alone would have led to the discontinuation of treatment. As a result, ultrasound has improved pregnancy rate, but at the same time increased the incidence of mild and moderate hyperstimulation (McArdle et al., 1983).

If hyperstimulation occurs, the size of the ovaries and the degree of hyperstimulation can be determined more accurately by ultrasound than by vaginal examination. There is no difference in mean preovulatory follicle diameter between spontaneous and gonadotropin induced cycles.

Besides gonadotropin stimulated cycles, cycles induced with $\mathrm{CC}$ have been investigated by ultrasound. O'Herlihy and coworkers (1982) and Smith and coworkers (1983) found the same preovulatory follicle diameters in patients with spontaneous and $\mathrm{CC}$-induced cycles. Giving a combination of $\mathrm{CC}$ and $\mathrm{hCG}, \mathrm{O}^{\prime}$ Herlihy and coworkers (1982) obtained an ovulation rate of $92 \%$, when the administration of hCG was timed ultrasonographically. Pregnancy occurred in $67 \%$ of the treated women. In 


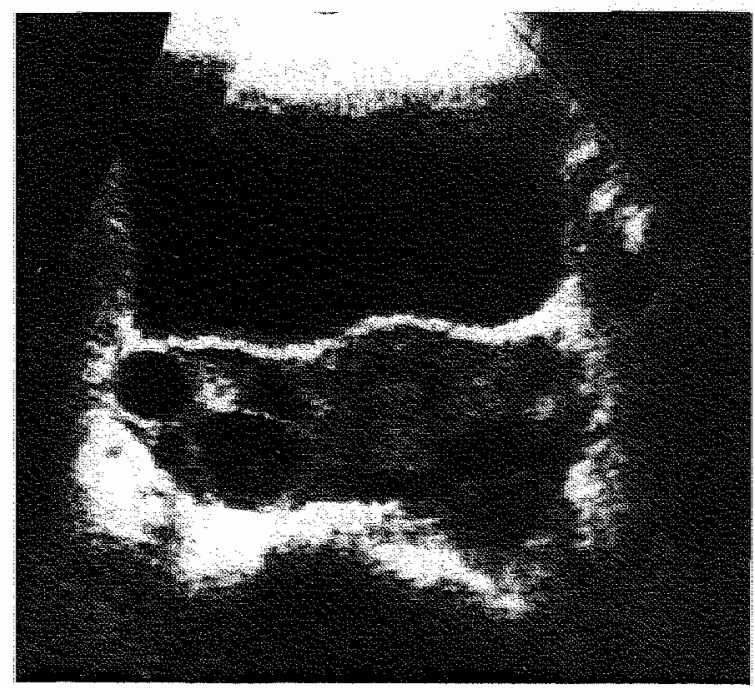

\section{Figtre 1.5}

Transverse scan showing multifollicular development in an IVF patient.

almost half of the CC-induced cycles, more than one dominant follicle is present, while in spontaneous cycles the incidence is only $5 \%$. Wetzels (1983) found significantly larger follicles in CC-induced cycles and follicular growth rate to be increased. If only unifollicular stimulated cycles were concerned, no statistically signilicant difference could be found, in comparison with follicular diameters in spontaneous cycles. Leerentveld and coworkers (1985) studied the follicle growth during CCinduced hyperstimulation in an in-vitro fertilization (IVF) program. In both unifollicular and multifollicular cycles the growth rate was increased. This abnormal growth rate probably is an expression of hyperstimulation.

In induced cycles the correlation between the serum estrogen concentration and the follicle size is less evident. On the other hand a good correlation exists between the serum estrogen levels and the total volume of the dominant follicles or the total ovarian volume (Vargyas et al., 1982).

Whereas hyperstimulation should be avoided in the treatment of anovulation, a different situation is found in IVF, in which the recruitment of multiple dominant follicles is pursued intentionally (Figure 1.5). Here the term superinduction could be used (McArdle et al., 1983). Ultrasound can be useful: the number and size of the follicles can be determined (DeCrespigny et al., 1981b). It is possible to see in which ovary the follicles are located. This is important in case one of the ovaries is inaccesible for laparoscopic aspiration of the follicle. Immediately before the oocyte collection ultrasound can be used, to check whether or not the follicles are still present. Follicle aspiration can be timed in different ways:

- Applying ultrasound first and hormonal assays afterwards.

As soon as a certain follicle size is reached blood samples are collected serially, to detect the spontaneous rise in LH level. 
- Ultrasound monitoring only.

After induction with CC Hoult and coworkers (1981) and Wood and coworkers (1981) administered hCG as soon as a mean follicle diameter of 18 to $20 \mathrm{~mm}$ was found. Laparoscopy was performed 32-36 hours later. From $80-90 \%$ of women treated, ova could be obtained.

- Most frequently a combination of ultrasound and serum or urinary estrogen assays is applied. HCG is administered as soon as a certain estrogen concentration per dominant follicle is reached (usually $1.2 \mathrm{nmol} / 1$ per follicle).

Smith and coworkers (1984) studied the ultrasonic aspect and thickness of the endometrium in IVF patients. They used 4 categories, which represented the endometrium response on estrogen stimulation. Their decision to give hCG was based on the endometrium response and on the follicular size. The number of cancelled cycles decreased, the fertilization rate per cycle increased and the pregnancy rate per ovum pickup improved. More investigations have to be undertaken to compare this method with the value of estrogen determinations alone.

Besides timing of the most proper moment for follicle aspiration, oocyte collection itself can be guided by ultrasound. Lenz and coworkers (1981) were the first to describe the ultrasound guided transvesical follicle puncture in 1981. Recently the transvaginal (Dellenbach et al., 1984) and transurethral (Parsons et al., 1985) puncture techniques have been introduced. In the mean time puncture methods have been improved considerably. The results of ultrasonic punctures are comparable with those of laparoscopic punctures (Wikland and Hamberger, 1984).

Finally, the embryo transfer can be performed under ultrasonic visualization (Strickler et al., 1985).

\subsection{Detection of disturbances of follicle growth and ovulation}

Since more agreement has been reached on follicle growth in normal, spontaneous and stimulated cycles, interest is growing in the detection of abnormal follicle growth patterns.

One of the most striking abnormalities which can be detected by ultrasound is the luteinized unruptured follicle (LUF) syndrome (Coulam et al, 1982). NitschkeDabelstein et al.,(1981) observed a cystic follicle, associated with an increased progesterone level and postulated that it was a luteinized unruptured follicle. This syndrome is characterized by signs of luteinization although no rupture of the follicle occurs (Koninckx et al., 1978; Marik and Hulka, 1978). Steroid hormone concentrations in the peritoneal fluid are low in the early luteal phase (Koninckx et al., 1980). The diagnosis is suspected if the follicle has not disappeared more than 48 hours after the LH peak. Wetzels (1983) described 5 LUF cycles. Although the number of cycles was small, the ovulation disorder seemed to be characterized by an increased follicle growth following the LH surge. Wetzels also described cycles in 
which ovulation occurred between 48 and 72 hours after the LH peak. In these cycles too, an increased follicle growth rate was observed. This phenomenon is perhaps a different manifestation of the same syndrome, with the distinction that the unruptured follicle does not keep its transsonic aspect, but suddenly becomes filled with intrafollicular echoes after a few days.

Unruptured follicles without signs of luteinization have also been described (Hackelöer et al., 1979). The $\mathrm{E}_{2}$ concentrations in these cycles rise to normal preovulatory levels. The LH peak, however, fails to occur. Another follicle appears, which eventually ovulates.

Cycle disturbances characterized by an asynchronism between hormonal and ultrasonographic parameters, were described by Polan and coworkers (1982). They found some follicles to disappear even before the $E_{2}$ peak and LH surge. They also found the P level and BBT to rise before follicle growth even was observed. The number of cycles reported is small, and perhaps the findings are merely the result of misinterpretation of the ultrasonic pictures or technical problems to visualize the follicles.

Geisthövel and coworkers (1983) reported retarded follicle growth in cycles with a prolonged follicular phase, which led to significantly smaller and irregular follicles. Impaired follicular development was associated with inadequate luteal function, as reflected by the BBT and by low luteal $P$ levels.

The ultrasonographic aspects of the PCOD have also been studied. Even before Hackelöer described his original study on follicular growth, Kun and Bosze (1973) reported on the possibility to detect the PCOD by ultrasound. The characteristic ultrasonographic features of PCOD are the size and the shape of the ovaries. Ovaries are usually symmetrically enlarged and the shape is more round than oval (Figure I.6). Usually they both have the same size. The classical picture of a PCOD patient is composed of menstrual disturbances, hirsutism and infertility. The disorder is usually associated with an abnormally high LH/FSH ratio and with high free testosterone levels. Histology reveals enlarged polycystic ovaries, with an increased amount of stroma. Histologic confirmation of the diagnosis PCOD requires invasive techniques. In most of the literature, however, the diagnosis is based on clinical and endocrine characteristics alone. Equipment with higher resolution has made it possible to give a more detailed description of the ultrasonographic characteristics. With the increasing use of diagnostic ultrasound in women with ovulatory disturbances, the ideas about the prevalence, clinical picture and management of PCOD are changing.

The ovaries in PCOD contain numerous cysts of equal size and arranged subcortically, or of varying size and spread throughout the ovarian stroma. An important feature is the increased amount of stroma. If the cysts are small $(2-5 \mathrm{~mm})$ and numerous, this is called polycystic ovaries. If cystic structures measure $6-10 \mathrm{~mm}$ and are spread throughout the ovarian parenchyma this is called multicystic ovaries (Franks et al., 1985). This ultrasonographic picture has clinical relevance, because the two groups have a quite different response on pulsatile LHRH therapy (Tucker et al., 


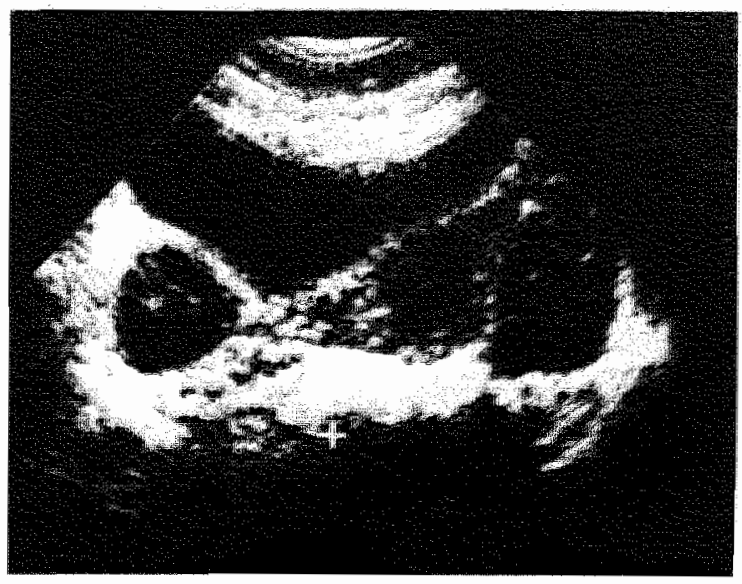

Figure 1.6

Transverse scan in a patient with polycystic ovarian disease showing the enlarged and round ovaries containing multiple small follicles.

1984). Especially patients with multicystic ovaries show a good response to LHRH treatment. Multicystic ovaries do not contain increased stroma and appear to be normal ovaries which receive abnormal gonadotropin stimulation. They resemble the ovaries usually seen during normal puberty when gonadotropin secretion gradually increases in frequency and amplitude (Stanhope et al., 1985).

\section{Aims of the study}

The present study has been designed to evaluate diagnostic ultrasound as an aid to the diagnosis and treatment of fertility problems. As a consequence, only infertility patients participated in the investigations presented in the chapters to follow (apart from the group of 45 female volunteers serving as controls in chapters IV and V). In contrast to other authors we are used to apply ultrasound as the first diagnostic step of the fertility screening in our clinic. We will compare the fertility investigations in a group of new infertility patients screened in a traditional way to those in a group of new patients screened by means of additional monitoring of follicle growth and ovulation and by means of ultrasound timing of diagnostic procedures. Special attention will be given to the results of the PC test (chapter II). Also the reliability of ovulation prediction by ultrasound was investigated (chapter III). This last item is controversial. Many authors describe ultrasound as a reliable predictor of the moment of ovulation. They usually base their conclusions on folli- 
cular growth curves obtained in groups of infertille patients and on the comparison of maximum preovulatory diameters in those patients. However, no large, methodologically correct, prospective study has been published yet, dealing with the real predictive value of every single follicle measurement with regard to the moment of follicle rupture. The reliability, c.q. the confidence limits of such a prediction will have to be determined. We determined the predictive value of ultrasonic follicle measurements in 100 women from consecutive infertile couples with a spontaneous ovulatory cycle and we validated the prediction rule in another 58 patients. The results will be described in chapter III.

A new subject to ultrasound studies is formed by menstrual cycle disturbances, especially ovulatory disorders and disturbances in endocrine-ovulatory relationships. The failure of the follicle to rupture at midcycle is an example of such an ovulatory disturbance. We decided to study the occurrence of this phenomenon in the 'normal' cycle, during ovulation induction therapy, in patients with postinfectious pelvic pathology and in patients with a luteal phase insufficiency. At the same time we investigated the value of ultrasound in evaluating luteal function in a standardized way. The results of these studies will be reported in chapters IV, V and VI.

\section{References}

Aiman,J.A.: History of human fertility.

In: Infertility, diagnosis and treatment. Ed. Aiman, J, New York: Springer Verlag, pp 1-16, 1984

Baird, D.T., Fraser, J.S.: Concentration of oestrone and oestradiol in follicular fluid and ovarian venous blood of women.

Clin Endocrinol (Oxf) 4:259, 1975

Baumann, J.E.: Basal body temperature: unreliable method of ovulation detection.

Fertil Steril 36:729, 1981

Beers, W.H.: Follicular plasminogen and plasminogen activator and the effect of plasmin on ovarian follicle wall.

Cell $6: 379,1975$

Billings, E.L., Billings, J.J., Brown, J.B., Burger, H.G.: Symptoms and hormonal changes accompanying ovulation.

Lancet $i: 282,1972$

Bomsel-Helmreich, O., Bessis, R., Huynen, L.V.N.: Cumulus oophoros of the preovulatory follicle assessed by ultrasound and histology.

In: Ulitrasound and Infertility Ed. Christie, A.D., Kent: Chartwell-Bratt, pp 105-120, 1981

Bomnar, J.: Biological approaches to ovulation detection.

In: Ovulation: Methods for its prediction and detection. Ed. Jeffcoate, S.L., Chichester: John Wiley and Sons, Lid pp 33-47, 1983 
Bowckaer, P.X.M.M.: Pertitoneumvloeistof, buochemische veranderingen tijdens de menstruelle cyclus. Thesis, Catholic University, Nijmegen, 1984

Brown, J.B.: Uninary excretion of oestrogens during the menstrual cycle.

Lancet 1320,1955

Bryce, R.L., Shuter, B., Sinosich, M.J., Stiel, J.N., Picker, R.H., Saunders, D.M.: The value of ultrasound, gonalotropin, and estradiol measurements for precise ovnlation prediction.

Ferti.i Steril $37: 42,1982$

Channing, $C_{n}:$ New developments in ovarian physiology.

In: Gamete quality and fertility regulation. Eds. Rolland, R., Heineman, M.J., Hillier, S.G., Vemer, H., Amsterdiam: Exerpta Medica pp, 3-30, 1985

Corner, G.W.Jr: Histologic dating of corpus luteum of mensiruation.

Am J Anat $98.377,1956$

Coulam, C.B., Hill, L.M., Breckle, R.: Ultrasonic evidence for luteinization of unruptured preovulatory follicles.

Fertil Sterill $37.524,1982$

DeCrespigny, L.C., O'Herlihy, C., Robinson, H.P.: Ultrasonic observation of the mechanism of human ovulation.

An J Obstet Gynecol 139:636, 1981a

DeCrespigny, L. $C_{*}$, O'Herlihy, $C_{*}$, Hoult, I.J., Robinson, H.P.: Ultrasound in an in vitro fertilization program.

Fertill Steril $35: 25,1981 \mathrm{~b}$

De Graaf, R.: De Mulierum organus Generatione inservientibus.

Leiden: Hackiania, 1672

Dellenbach, P., Nisand, I., Moreau, L., Feyer, B., Plumere, G., Gerlinger, P., Brum, Bu, Rumpler, Y.: Transvaginal, sonographically controlled ovarian follicle puncture for egg retriewal.

Lancet $\mathbb{\|}: 1467,1984$

DiZerega, G.S., Marut, E.L., Turner, C.K., Hodgen, G.D.: Asymmetrical ovarian function during recruitment and selection of the dominant follicle in the menstrual cycle of the rhesus monkey.

J Clin Endocrinol Metab 51:698, 1980

Doyle, J.B.: Exploratory culdotomy for observation of tubo-ovarian physiology at ovulation time. Fertil Sterill 2:475, 1951

Filssa, M.K., Hudlson, K., Docker, M.F., Sawers, R.S., Newton, J.R.: Ultrasound follicle diameter meastitement: an assessment of interobserver and intraobserver variation.

Fertil Steril 44:751, 1985

Espey L.L.: Ovarian proteolytic enzymes and ovulation.

Biol Reprod 10:216, 1974

Fleming, R., Coutts, M.R.T.: Prediction of ovulation in women using a rapid progesterone radioimmunossay.

Clin Endocrinol 16:171, 1982

Franks, S., Adaums, J., Mason, H., Polson, D.: Ovulation disorders in women with polycystic ovary syndrome.

Clin Obstet Gynaeed 12:605, 1985 
FreundI, G. Terinde, R., Distler, W., Bammeister, A.; Herberger, $\mathfrak{J}_{\text {, }}$ Kozlowski, P.: Serum levels of oestradiol-17-b and luteinizing hormone rellated to follicular growth as monitored by ultrasound in women with nomal menstrual cycles.

Acta Endocrinologica $96: 370,1981$

Fritx, M.A., Speroff, L.: The endocrinology of the menstrual cycle: the interaction of folliculogenesis and neuroendocrine mechanisms.

Fertil Steril 38:509, 1982

Geisthövel, F., Skubsch, U., Zabel, G., Schillinger, H., Breckwoldt, M.: Uttrasonographic and hormonal studies in physiologic and insufficient menstrual cycles.

Fertil Steril 39:277, 1983

Gougeon, A.: Rate of follicle growth in the human ovary.

In: Follicular maturation and ovulation. Eds. Rolland, R., van Hall, E. ., Hillier, S. O., McNatty, K.P., Schoemaker, J., Amsterdam: Excerpta Medica, pp 155 163, 1982

Hackelöer, B.J., Nitschke, S., Daume, E., Sturm, G., Buchholz, R.: Ultraschalldarstellung von Ovarverănderungen bei Gonadotropinstimulierung.

Geburtsh u Frauenheilk 37:185, 1977

Hackelöer, B.J., Robinson, H.P.: Ultraschalldarstellung des wachsenden Follikels und Corpus luteum im normalen physiologischen Zyklus.

Geburtsh u Frauenheilk 38:163, 1978

Hackelöer, B.J., Fleming, R., Robinson, H.P., Adam, A.H., Coutts, J.R.T.: Correlation of ultrasonic and endocrinologic assessment of human follicular development.

Am J Obstet Gynecol 135:122, 1979

Hackelöer, B.J.: Ultrasound scanning of ovarian cycle.

J Vitro Fert Embryo Transfer 1:217, 1984a

Hackelöer ${ }_{\text {, }}$.J.: The role of ultrasound in female infertility management.

Ultrasound Med Biol 10:35, 1984b

Helmond, F.A., Simons, P.A., Hein P.R.: The effects of progesterone on estrogen-induced luteinizing hormone and follicle-stimulating hormone release in female rhesus monkey.

Endocrinology $107: 478,1980$

Hodgen, G.D.: The dominant follicle.

Fertil Steril $38: 281,1982$

Hoff, J.D., Quigley, M.E., Yen, S.S.C.: Hormonal dynamics at midcycle: a reevaluation.

J Clin Endocrinol Metab 57:792, 1983

Hoult, I.J., DeCrespigny, L.C., O'Herlihy, C., Speirs, A.L., Lopata, A., Kellow, G., Johnston, I., Robinson, H.P.: Ultrasound control of clomiphene/chorionic gonadotropin stimulated cycles for oocyte recovery and in vitro fertilization.

Fertil Steril $36: 316,1981$

Insler, V., Melmed, H., Eichenbrenner, I., Serr, D.M., Lunenfeld, B.: The cervical score: a simple semiquantitative method for monitoring of the menstrual eycle.

Int $J$ Gynaecol Obstet 10:223, 1972

Karsch, F.J., Sutton, G.P.: An intra-ovarian site for the luteolytic action of estrogen in the rhesus monkey.

Endocrinology 98:553, 1976 
Kerin, J.F.P.: Determination of the optimal timing of insemination in women.

In: Frozen Human Semen. Eds. Richardson, D., Joyce, D., Symonds, M., London: RCOG, pp 105 132, 1979

Kerin, J.FF, Edmondls, D.K., Warnes, G.M., Con, L.W., Seamark, R.F., Matthews, C.D., Young, G.B., Baird, D.T.: Morphological and functional relations of graafian follicle growth to ovulation in women using ultrasonic, laparoscopic and biochemical measurements.

Br J Obstel Gynateol $88: 81,1981$

Knaws, H.: Die periodische Frucht- und Unfruchtbarkeit des Weibes.

Zentralblatl fur Gynakologie 57:1393, 1933

Kuobil, E.: The neuroendocrine control of the menstrual cycles.

Recent Prog Horm Res 36:53, 1980

Kohlogyashi, Y., Samtall, R., Wright, K.H., Wallach, E.E.: The effect of prostaglandin synthesis inhibition by indomethacin on ovulation and ovum maturation in the in vitro perfused rabbit ovary.

Am J Obstet Gynecoll 141:53, 1981

Koninckx, P.R., Heyns, W.J., Corveleym, P.A., Brosens, I.A: Delayed onset of luteinization as a cause of infertility.

Fertil Steril 29:266, 1978

Koninckx, P.R., De Moor, P., Brosens, I.A.: Diagnosis of the luteinized unruptured follicle syndrone by steroid hormone assays on peritoneal fluid.

Br J Obstet Gynaecol 87:929, 1980

Kratochwil, A., Urban, G., Friedrich, F: Uitrasonic tomography of the ovaries.

Ann Chir Gynaecol Fenn 61:211, 1972

Kun, L., Bosze, P.: Die Bedeutung der Ultraschalluntersuchung fur die Diagnosestellung des palyzystischen Ovars.

Geburtsh u Frauenheilk 33:452, 1973

Leerentveld, R.A., wan Gent, I., van der Stoep, M., Wladimiroff, J.W.: Ultrasonographic assessment of Graafian follicle growth under monofollicular and multifollicular conditions in clomiphene citratestimulated cyclles.

Fertil Steril $43: 565,1985$

Lemaire, W.J., Leidner, R., Marsh, J.M.: Pre and post ovulatory changes in the concentration of prostaglandins in rait Craafian follicles.

Prostaglandins $9: 221,1975$

Lenton, E.A., Weston, G.A., Cooke, 1.D.: Problems in using basal body temperature recordings in an infertility clinic.

Br Med J i:803, 1977

Lenz, S., Lauritsen, J.G., Kjellow, M.: Collection of human oocytes for in vitro fertilization by ultrasow nically guided follicle puncture.

Lancet i:1163-1164, 1981

Mathuts, J.B., Look, P.F.A.van, Michie, E.A.: Changes in volume, total protein and ovarian steroid concentrations of peritoneal fluid throughout the human menstrual cycle.

I Endocrinol 76: 123,1978

Marik, J., Hulka, J.: Luteinized unruptured follicle syndrome: a subtle cause of infertility.

Fertil Sterill $29: 270,1978$ 
Marninho, A.O., Sallam, H.N., Goessens, L., Collins, W.P., Rodeck, C.H., Campbell, S.: Real time pelvic ultrasonography during the periovulatory period of patients attending an artificial insemination clinic.

Fertil Steril $37: 633,1982$

MeArdle, C.R., Seibel, M.M., Weinstein, F., Hann, L.E., Nickerson, C., Taynor, M.L.: Induction of ovulation monitored by ultrasound.

Radiology $148: 809,1983$

McIntosh, J.E.A., Matthews, C.D., Crocker, J.M., Broom, T.J., Cox, L.W.: Predicting the luteinizing hormone surge:relationship between the duration of the follicular and luteal phases and the length of the human menstrual cycle

Fertil Steril 34:125, 1980

MeNatty, K.P.: Ovarian follicular development from the onset of luteal regression in thumans and sheep. In: Follicular maturation and ovulation. Eds. Rolland, R., van Hall, E.V., Hillier, S.G., McNatty, K.P., Schoemaker, J., Amsterdam: Exerpta Medica, pp 1-18, 1982

Mendelson, E.B., Friedman, H., Neiman, H.L., Calenoff, L., Vogelizang, R.L., Cohen: The role of ima* ging in infertility management.

Am J Radiol 144:415, 1985

Moghissi, K.S.: Accuracy of basal body temperature for ovulation detection.

Fertil Steril 27:1415, 1976

Nitschke-Dabelsteï, S., Hackelöer, B.J., Sturm, G.: Ovulation and corpus luteum formation observed by ultrasonography.

Ultrasound Med Biol 7:33, 1981

Noyes, R.W., Hertig, A.T., Rock, J.: Dating the endometrial biopsy.

Fertil Steril 1:3, 1950

Ogino, K.: Ovulationstermin und Konzeptionstermin.

Zentralblatt fur Gynäkologie 54:464, 1930

O'Herlihy, C., Robinson, H.P., DeCrespigny, L.C.: Mittelschmerz is a preovulatory symptom.

Br Med J 280:986, 1980a

O'Herlihy, C., DeCrespigny, L.C., Lopata, A., Johnston, 1., Hoult, I., Robinson, H.P.: Preovulatory follicular size: a comparison of ultrasound and laparoscopic measurements.

Fertil Steril $34: 24,1980 \mathrm{~b}$

O'Herlihy, C., Pepperell, R.J., Robinson, H.P.: Ultrasound timing of human chorionic gonadotropin administration in clomiphene-stimulated cycles.

Obstet Gynecoll 59:40, 1982

Parsons, J., Booker, M., Goswany, R., Akkerman, J., Riddl, A., Sharme, V., Wilson, L., Whitehead, M., Campbell, S.: Oocyte retrieval for in vitro fertilisation by ultrasonically guided needle aspiration vir the urethra.

Lancet $\mathrm{i}: 1076,1985$

Peters, H., McNatty, K.P.: Morphology of the ovary.

In: The ovary. Eds, Peters, H., MeNatty, K.P., London: Granada Publishing, pp 12-21, 1980.

Peters, H., Byskov, A.G., Grinsted, J.: Follicular growth in fetal and prepubertal ovaries in human and other primates.

In: Gynaecological Endocrinology. Eds. Ross G.T. and Lipsett M.B., Philadelphia: W.B. Saunders Co Ltd., pp 469-84, 1978 
Picker, R.H., Smith, D.H., Tucker, M.H., Saunders, D.M.: Ultrasonic signs of imminent owulation. J Clin Uitrasound $11: 1,1983$

Polan, M.L., Totora, M., Caldwell, B.V., DeCherney, A.H., Haseltine, F.P., Kase, N.: Abnormal ovarian cycles as diagnosed by ultrasound and serum estradiol levels.

Fertil Steril $37: 342,1982$

Portiondo, J.A., Penia, J., Otaola, C., Echanojauregui, A.D.: Absence of owulation stigma in the conception cycle.

J Fertil 28:52, 1983

Renaud, R.L., Macier, J., Dervain, 1., Ehret, M.C., Aron, C. Plas-Roser, S., Spira, A., Pollack, H.: Echographic study of follicualir maturation and ovulation during the normal mensirual cycle.

Fertil Steril $33: 272,1980$

Riley, G.M., Dontas, E., Grill, B.: Use of vaginal smears in detecting the time of ovulation. Fertil Steril $6: 86,1955$

Rönmberg, L., Ylöstalo, P., Joupilla ; P.: Ultrasound to time insemination.

Lancel $1: 669,1978$

Ross, G.T. Cargille, C.M., Lipset, M.B., Rayford, P.L.* Marchall, J.R., Strott, C.A., Rodbard, D.: Pituitary and gonadal hormones in women during spontaneous and induced ovwlatory cycles.

Recent Prog Horm Res 26:1, 1970

Sakamoto, C., Nakano, H.: The echogenic endometrium and alterations during menstrual cycle. Int J Gynaecol Obstet 20:255, 1982

Sallam, H.N., Marinho, A.O., Collins, W.P., Rodeck, C.H., Campbell, S.: Monitoring gonadotrophin therapy by real-time ultrasonic scanning of ovarian follicles.

Br J Obstet Gynaecol 89:155, 1982

Schröder, R.: Der normale menstruelle Zylklus der Uterusschleimhaut.

Berlin: Hirschwald, 1913

Seilbel, M.M., MeArdle, C.R., Thompson, I.E., Berger, M.J., Taymor, M.L.: The role of ultrasound in ovulation induction: a critical appraisal.

Fertil Steril 36:573, 1981

Shoupe, D., Spita, L., Osborn, C., Page, M., Mishell, D.Jr., Lobo, R.: Effects of progesterone (P) antit.gonism on gonadotropins at midcycle and during the luteal phase.

In: Scientific program and abstracts. Society for Gynecologic investigation. 33rd annual meeting Toronto 19.22 March, 1.986 abstract 20

Sims, J.M.: Clinical notes on uterine surgery.

New York: Wood, 1866

Smith, B., Porter ${ }_{n}$ R., Ahuja, U., Craft, l.: Ultrasound assessment of endometrial changes in stimulated cycles in an in witro fertilization and embryo transfer program.

JVitro Fert Embryo Transfer $1: 233,1984$

Smith, D.H., Picker, R.H., Simosich, M.J., Saunders, D.M.: Assessment of ovulation by ultrasound and estradiol levels during spontaneous and induced cycles.

Fertil Steril 33:387, 1980

Smith, D.H., Picker, R.H., Sinosich, M.J., Saunders, D.M., Grudzinskas, J.G.: Effects of clomiphene administration on ovarian function as measured by estradiol and ultrasound.

Obstet Gynecol 61:695, 1983 
Sotrel, G., Helvacioglu, A., Dowers, S., Scommegna, S., Auletta, F.J.: Mechanisms of luteolysis: effect of estradiol and prostaglandin $\mathbb{F}$ on corpus luteurn luteinizing hormone/human chorionic gonadotropin receptors and cyclic nucleotides in the thesus monkey.

Am I Obstet Gynecol 139:134, 198!

Stanger, J.D., Yovich, J.L.: Failure of human oocyte release at ovulation.

Fertil Steril $41: 827,1984$

Stanhope, R., Adams, J., Jacobs, H.S., Brook, C.G.D.: Ovarian ultrasound assessment in normal children, idiopathic precocious puberty, and during low pulsatile gonadotrophin releasing hormone treatment of hypogonadotrophic hypogonadism.

Arch Disease Chilldr 60:116, 1985

Steptoe, P.C.: Laparoscopy in gynaecology.

Edinburgh: Livingstone, 1967

Strickller, R.C., Christianson, C., Crane, J.P. Curato, A., Knight, A.D., Yang, V.: Ultrasound guidance for human embryo transfer.

Fertil Steril $43: 54,1985$

Swanson, M., Sauerbrei, E.E., Cooperberg, P.L.: Medical implications of ultrasonically detected polycystic ovaries.

J Clin Ultrasound $9: 219,1981$

Testar, J., Frydman, R.: Minimum time lapse between luteinizing hormone surge or human gonadotropin administration and follicular rupture.

Fertil Steril 37: 50, 1982

Testart, J., Thebault, A., Sonderes, E., Frydman, R.: Premature ovulation after ovarian ultrasonography.

Br J Obstet Gynaecol 89:964, 1982

Tsafriri, A., Lindner, H.R., Zor, U., Lamprecht, S.A.; In vitro induction of meiotic division in follicleenclosed rat oocytes by $\mathrm{LH}$, cyclic AMP and prostaglandin E2.

J Reprod Fertil $31: 39,1972$

Tucker, M., Adams, J., Mason, W.P., Jacobs, H.S.: Infertility, megalocystic and polycystic ovaries: differential response to LHRH therapy.

Upsala J Sci 89:43, 1984

Van de Velde, Th.: Uber der Zusammenhang zwischen Ovarialfunction, Wellenbewegung und Menstu alblutung und über die Enstehung des sogenannten Mittelschmertzes.

Bonn: Haarlem F, p 39, 1905

Vanrell, J.A., Balasch, J., Fuster, J.S., Fuster, R.: Ovulation stigma in fertile women. Fertil Steril $37: 712,1982$

Vargyas, J., Marrs, R., Kletzky, O., Mishell, D.R.: Correlation of ultrasonic measurement of ovarian follicle size and serum oestradiol levels in ovulatory patients following clomiphene citrate for in vitro fertilization.

Am J Obstet Gynecol 144:569, 1982

Wetzels, L.C.G., Hoogland, H.J.: Relation between ultrasonographic evidence of ovulation and hormonal parameters: luteinizing hormone surge and initial progesterone rise.

Fertil Steril 37:336, 1982 
Wektels, L.C.G., Hoogland, H.J., de Haan, J.: Basal body temperature as a method of ovulation detecthon: comparison with ultrasonographical findings.

Gynecol Obstet Inwest $13: 235,1982$

Wetzells, L.C.C.: Ultrasonographical aspects of follicle growth.

Thesis, University of Limburg, Maastricht, 1983

WHO Task Force: Temporal relationships between owulation and defined changes in the concentration of plasma estradiol-17-b, luteinizing hormone, follicle stimullating hormone and progesterone. I. Probit analysis.

Am J Obstet Gynecol 138:383, 1980

Wikland, M., Hamberger, L.. Ultrasound as a diagnostic and operative tool for in vitro fertilization and embryo replacement (IVF/ER) programs.

JVitro Fert Embryo Transfer 1:213, 1984

Wood, C., Trounson, A., Leeton, J., Talbot, J.Mc.K., Buttery, B., Webb, 1., Wood, J., Jessup. D.: A clinical assessment of nine pregnancies obtained by in witro fertilization and embryo transfer.

Fertil steril $35: 502,1.981$

Yen, S.S.C., Tsail, C.C., Naftolin "F., Vandenberg, G., Ajabor, L.: Pulsatile patterns of gonadotropin release in subjects with and without ovarian function.

I Clin Endocrinol Metab 34:671, 1972

Ylöstalo, P., Rönniberg, IL., Joupillia, P..: Measurement of the ovarian follicle by ultrasound in ovulation indluction.

Fertil Steril 31:651, 1979

Young, J.R., Jaffe, R.B.: Strength-duration characteristics of estrogen effects on gonadotropin response to gonadofropin-releasing hormone in women. If Effects of varying concentrations of estradiol.

J Clin Endocrinol Metab 42:432, 1976

Zegers-Hochschild, F., Gómez Lira, C., Parada, M., Altieri Lorenzini, E.* A comparative study of the follicular growth profille in conception and nonconception cycles.

Fertil Steril $41: 244,1984$ 


\section{Chapter II}

\section{Ultrasound increases the prognostic value of the postcoital test}

Hamilton, C.J.C.M., Evers, J.L.H., de Haan, J.

(Gynecologic and Obstetric Investigation 21:80, 1986)

(with permission)

\section{Summary}

The prognostic value of the postcoital ( $\mathrm{PC})$ test was studied in two groups of women in whom the infertility workup differed only in the way the PC test was timed. Fifty patients were investigated in a traditional way. In this group the PC test failed to have any substantial prognostic value. In a second group consisting of 54 patients, the PC test was timed applying ultrasonographic criteria for ovarian follicular development. This resulted in a highly significant prognostic test. Timing of the PC test by ultrasound enhanced both the reliability and the efficiency of the standard fertility investigation. 


\section{Introduction}

Even more than 100 years after its introduction as an important tool in the investigation of human fertility by Sims (1866) and Huhner (1913), no agreement exists about the prognostic value of the postcoital (PC) test. Some authors have reported a correlation between the number of motile spermatozoa per high power field (HPF) in the cervical mucus and the eventual pregnancy rate (Buxton and Southam, 1958; Davajan et al., 1970). Others were unable to corroborate this finding (Ginner et al., 1974; Gibor et al., 1970). The relevance of the test is still questioned. The predictive value of the PC test is influenced in particular by the number of false-negative test results (i.e. the negative test results in women who yet become pregnant). The most common cause of a negative PC test is inappropriate timing. In no study the exact time interval between the PC test and ovulation has been taken into account.

The aim of the present study was to investigate the influence of optimal timing upon the reliability of the PC test. Ultrasound was applied to monitor ovarian follicle development and ovulation, as published before (Hamilton et al., 1985).

\section{Material and methods}

We examined 104 consecutive infertile patients, who for the first time visited our outpatient infertility clinics. Patients with a duration of the menstrual cycle of more than 6 weeks were excluded from the study. No other exclusion criteria were applied.

Fifty patients were investigated in a traditional way. They will be referred to as the TRADINVEST group. Every patient of this group kept a basal body temperature (BBT) chart for retrospective ovulation detection. The first PC test was planned between 16 and 14 days before the expected onset of the next menstrual period. If the test was negative the test was repeated on alternating days, until, according to the mucus score and the BBT, the estimated day of ovulation had passed. If the test was still negative, serial tests were repeated in subsequent cycles. If still no adequate cervical mucus was found, $0.02 \mathrm{mg}$ of ethinyl-estradiol (EE) was administrated from day 19 to day 15 before the expected onset of menstruation. In case of suspected anovullation clomiphene citrate (CC) was given.

In the remaining 54 patients we monitored ovarian follicle development and ovulation by ultrasound. This group will be referred to as the USINVEST group. Ultrasound scans were started on day 8 of the cycle and were repeated every other day until the follicle had reached a mean diameter of $15 \mathrm{~mm}$. Subsequently, daily measurements were performed until ovulation had taken place. The first PC test was performed as soon as the follicle had reached a mean diameter of at least $17 \mathrm{~mm}$. 


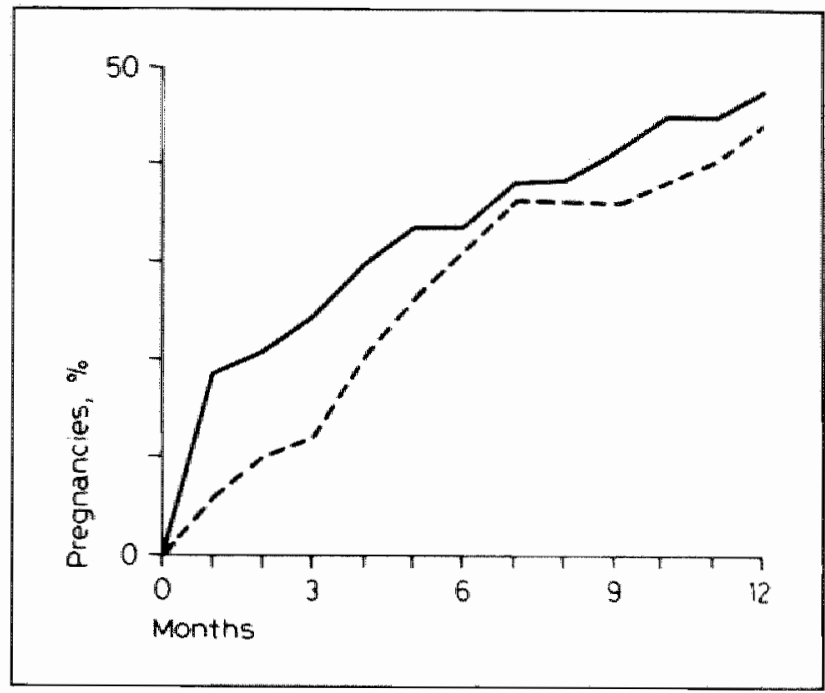

Figure II.1

Life table analysis of 50 infertility patients, who were investigated in a traditional way (broken line) and 54 infertility patients, in whom follicular development was monitored by ultrasound (solid line).

Subsequently, PC tests were performed on alternating days until ultrasound evidence of follicle rupture was obtained. In the USINVEST group the length of the luteal phase could be calculated exactly.

The $\mathrm{PC}$ test was considered positive if five or more forward-moving spermatozoa per HPF were observed. We did not use more detailed counts of spermatozoa per HPF, because this does not seem to give additional information (Jette and Glass, 1972; Portuondo et al., 1982).

Patients were instructed to have intercourse the night before the PC test. All tests were performed between 12 and $18 \mathrm{~h}$ after intercourse. Cervical mucus was collected using a disposable tuberculin syringe. A cervical mucus score was assessed immediately, by examining the quantity, spimnbarkeit, lucidity, fern test and cellularity. The score of each parameter varied from 0 to 3 , adding up to a maximum score of 15 (Roumen et al., 1982).

Our standard fertility investigation consists of two parts: the basal screening part in which semen, mucus, ovulation and semen-mucus interaction are studied, and the second part in which tubal patency and intrapellvic disorders are investigated. In the TRADINVEST group the basal screening started with the first BBT, in the USINVEST group with the first scan. The results of this study are expressed in terms of sensitivity, specificity, and predictive value of a positive and negative PC test, related to the occurrence of pregnancy within a follow-up period of 1 year (Stempel, 1982). Also the proportion of false-positive and false-negative PC tests will be given. Both the results of the best PC test obtained in the first examination cycle and the 
best $\mathrm{PC}$ test obtained in the entire screening period are presented.

The sensitivity is defined as the fraction of patients with a negative $\mathrm{PC}$ test in the group of women who did not achieve a pregnancy.

The specificity is defined as the fraction of patients with a positive $\mathrm{PC}$ test in the group of women eventually becoming pregnant.

The rate of false-negative $\mathrm{PC}$ tests is defined as the fraction of patients that, although eventually becoming pregnant, had a negative PC test as best result.

The rate of false-positive $P C$ tests represents that fraction of patients, that, although not achieving a pregnancy, had a positive $P C$ test result.

We also compared the duration of the basal screening period and the number of $\mathrm{PC}$ tests performed per cycle. Another way to evaluate the contribution of ultrasound to the fertility investigation is to compare the percentages of normal findings in the first examination cycle (such as the occurrence of ovulation, optimal cervical mucus, and a positive PC test), as detected by the two different ways of approach. Eventually we compared the need for $\mathrm{CC}$ and $\mathrm{EE}$ during the screening period. $\mathrm{CC}$ was administrated in an attempt to treat suspected anovulation and luteal defects or to reduce the duration of the cycle. EE was given in an attempt to improve presumed poor cervical mucus qualities.

Statistical significance of differences was tested by means of the chi-square test or the Fisher exact probability test.

\section{Results}

The mean age of the patients in the two groups was 26.7 and 27.3 years, respectively. The mean duration of infertility was 2.0 years in both groups. Eight of 50 patients in the TRADINVEST group and 13 of 54 patients in the USINVEST group had a history of secondary infertility. No other exclusion criterion than oligomenorrhea was applied. In both groups a comparable proportion of patients had a partner with normospermia (62 and $66.6 \%$, respectively). The eventual pregnancy rates in case of normospermia were similar. Finally, the overall pregnancy rates after a follow-up period of 1 year were, as is shown in Figure II.1, in both groups almost the same, confirming that the two groups are comparable. In both groups 3 patients became pregnant before a PC test had been performed.

Table II.1 shows the results of the best PC test obtained in the first examination cycle, in a two-by-two matrix display. The results of both the TRADINVEST group and the USINVEST group are presented.

Table II. 2 shows the results of the best of all PC tests obtained during the entire screening period.

Table 1I. 3 summarizes the results of the first two tables in terms of sensitivity, specificity and predictive value of a positive and a negative PC test (i.e. the pregnancy 
Table II.I

Results of the best PC rest obtained in the first examination cycle as related to the occurrence of pregnancy within a follow-up period of I year.

\begin{tabular}{lll}
\hline $\begin{array}{l}\text { Not } \\
\text { pregnant }\end{array}$ & Pregnant Total \\
\hline
\end{tabular}

TRADINVEST group, first cycle

\begin{tabular}{lrrr} 
Negative PC test & 26 & 10 & 36 \\
Positive PC test & 5 & 6 & 11 \\
\cline { 2 - 4 } & 31 & 16 & 47 \\
\hline
\end{tabular}

USINVEST group, first cycle

\begin{tabular}{lrrr} 
Negative PC test & 22 & 3 & 25 \\
Positive PC test & 10 & 16 & 26 \\
\cline { 2 - 4 } & 32 & 19 & 51
\end{tabular}

\section{Table $\| 1.2$}

Resulus of the best PC test obtained during the entire screening period as retated to the accurrence of pregnancy within a follow-up period of 1 year

Not Pregnant Total pregnant

TRADNVEST group, entire screening period

\begin{tabular}{lrrr} 
Negative PC test & 22 & 7 & 29 \\
Positive PC test & 9 & 9 & 18 \\
\cline { 2 - 4 } & 31 & 16 & 47
\end{tabular}

USINVEST group, entire screening period

\begin{tabular}{llrl} 
Negative PC test & 17 & 0 & 17 \\
Positive PC test & 15 & 19 & 34 \\
\cline { 2 - 4 } & 32 & 19 & $5 !$
\end{tabular}

TRADINVEST = traditional fertility investigation;

USINVEST = ultrasound-guided fertility investigations.

\section{Table II.3}

Mean values and $95 \%$ confidence limits of the predictive values of a positive and a negative PC test, sensitivity, specificity, and the rates of false-positive and false-negative test results in both the TRADINVEST group and the USINEEST group

$\begin{array}{llllll}\text { Predictive } & \text { Predictive } & \text { Sensitivity } & \text { Specificity } & \text { False- } & \text { False- } \\ \text { value } & \text { value } & \text { PC test } & \text { PC test } & \text { positive } & \text { negative } \\ \text { positive } & \text { negative } & 0 \% & \% & \text { PC test } & \text { PC test } \\ \text { PC test } & \text { PC test } & & & \% \% & \% \% \\ \% \% & & & & \end{array}$

\section{TRADINVEST}

$\begin{array}{lllllll}\text { First cycle } & 55(28-79) & 28(16-44) & 84(67-93) & 38(18-61) & 16(7-33) & 63(39-86) \\ \text { All cycles } & 50(29-71) & 24(12-42) & 71(53-84) & 56(33-84) & 29(16-47) & 44(16-67)\end{array}$

\section{USINVEST}

First cycle

$\begin{array}{rr}62(43-78) & 12(4-30) \\ 56(39-71) & 0(0-18)\end{array}$

$69(51-82)$

84. (62-94) $31(18-49)$

$16(6-38)$

All cycles

$56(39-71)$

$53(36-69)$

$100(83-100) \quad 47(31-64)$

$0(0-17)$

Overlapping confidence intervals exclude statistically significant differences. Both the results of the best PC test obtained in the first examination cycle (first cycle) and in the entire screening period (all cycles) are presented. 


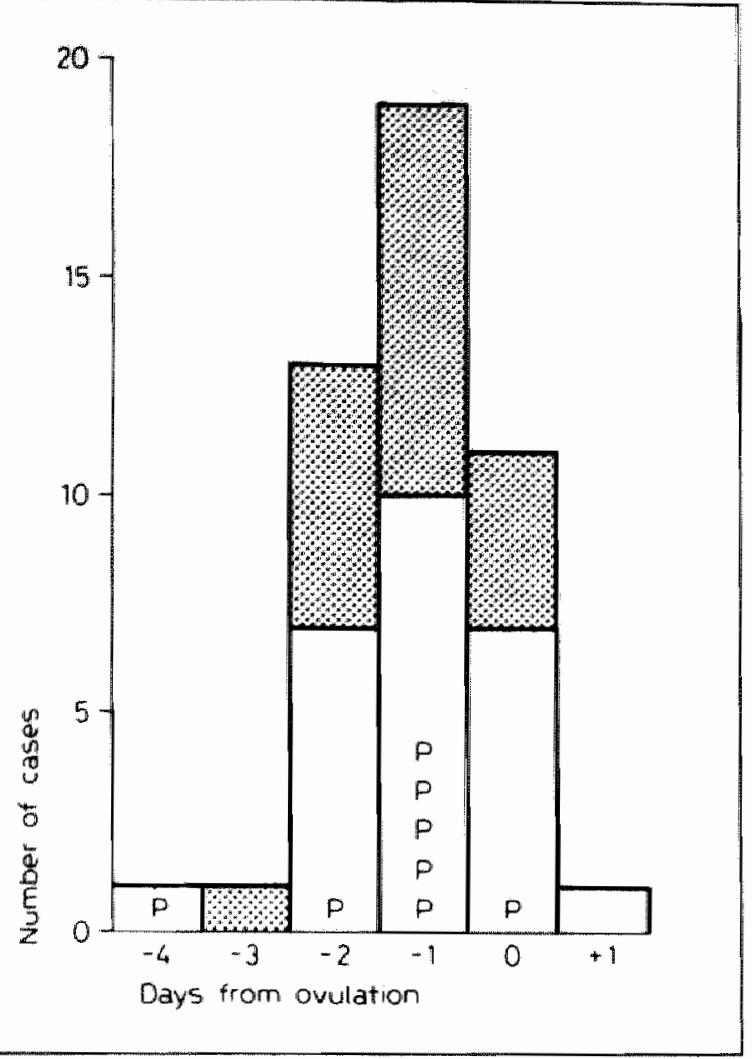

Figure $\Pi_{.2} 2$

Time interval between the last PC test and the day of utrasonographical ovulation (day 0) in 46 infertile patients. Positive PC test (white area) and negative PC test (dotted area) are shown. $P=$ Pregnancy.

rate after a follow-up period of 1 year in case of a positive or a negative PC test). Also the percentages of false-positive and false-negative $\mathrm{PC}$ tests are presented. In the TRADINVEST group there is no substantial difference in pregnancy rate between patients with a positive and patients with a negative test in the first cycle ( 55 and $28 \%$, respectively), with overlapping $95 \%$ confidence intervals, $28-79 \%$ and $16-44 \%$ ). Even when we consider the results of the best of all PC tests in the entire screening period, no significant difference in prognostic value exists (50 and $24 \%$, respectively, $95 \%$ confidence intervals, $29-71 \%$ and $12-42 \%$ ). More adequate timing of the PC test by means of ultrasound in the USINVEST group resulted in considerably more positive PC tests and less false-negative tests (Table II.1 and II.2). In this group a significant difference $(p<0.001)$ in pregnancy rate was found between patients with a positive and patients with a negative $\mathrm{PC}$ test (62 and $12 \%$, respectively, $95 \%$ confidence intervals, $43-78 \%$ and $4-30 \%$ ). When the best PC tests of the entire screening period are considered the difference is still significant ( 56 and $0 \%$, 


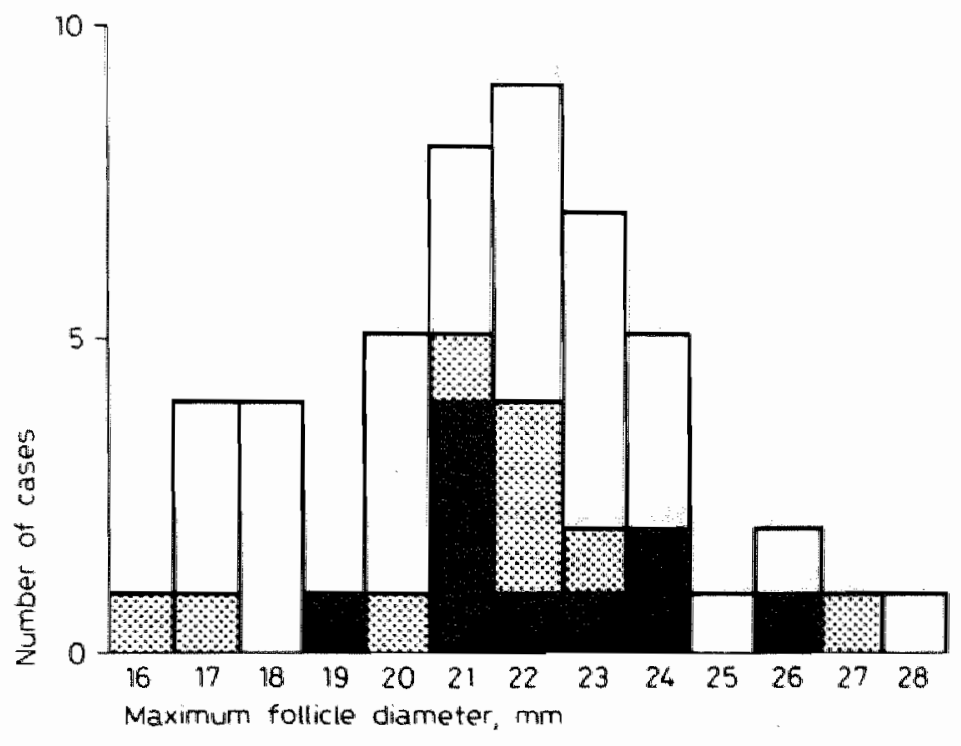

\section{Figure 11.3}

Distribution of the maximum preovulatory follicle diameter in 49 ovulatory infertility patients. Nineteen patients eventually achieved a pregnancy (dotted and black squares). In 10 patients the ultrasound-monitored cycle turned our to be the conception cycle (black squares).

respectively, 95\% confidence intervals, $39-71 \%$ and $0-18 \%$ ). No pregnancy at all occurred in those patients of the USINVEST group whose best PC test of the entire screening period was negative.

Figure II. 2 shows that in the USINVEST group in all but 2 patients the time interval between the PC test and ovulation was less than 2 days. In most of the pregnancies achieved during the ultrasound-monitored cycles, the last PC test was performed on the day before ovullation.

Figure II.3 shows the wide variation in maximum follicle diameter in the 49 ovulatory cycles monitored. Even in the group of patients who eventually achieved a pregnancy, this spread is considerable. The maximum preovulatory follicle diameter in conception cycles ranged from 19 to $26 \mathrm{~mm}$. Ultrasound reduced the duration of the screening period of the basal fertility investigation from 18.1 to 4.4 weeks.

In the TRADINVEST group an average of 2.2 PC tests was performed per cycle. In the USINVEST group this number was 1.3 per cycle. The total number of visits 
to the outpatient infertility clinic was lower in the USINVEST group (5.7 and 2.9, respectively). In the USINVEST group, in addition, an average number of 7 ultrasound scans was performed.

Looking at the rate of normal findings in the first examination cycle, we encountered remarkable differences. Confirmation of ovulation (BBT rise) could be obtained in $48 \%$ of the patients in the TRADINVEST group. In the remaining $52 \%$ the BBT could not be interpreted or was monophasic.

In the USINVEST group confirmation of ovulation (ultrasonographic evidence of follicle rupture) could be obtained in $90.7 \%$ of the patients during the first cycle. Anovulation was observed in $5.6 \%$ of these patients, whereas in $3.7 \%$ the findings fulfilled the ultrasonographic criteria of the luteinized unruptured follicle syndrome (Hamilton et al., 1985). Obviously, this last diagnosis would have been missed, had traditional methods been used.

In all but one ultrasonography cycle, ultrasonographic findings were in agreement with hormonal investigations. In the later, rather long cycle, which turned out to be ovulatory according to the midluteal progesterone elevation, no follicle growth was observed, because ultrasound scans were discontinued too early. Good cervical mucus qualities (cervical mucus score higher than $8 / 15$ ) in the first examination cycle were found in $52 \%$ of patients in the TRADINVEST group and in $83.3 \%$ of the patients in the USINVEST group. A positive PC test was found in 22 and $48.2 \%$, respectively.

CC was administrated to $32 \%$ of the patients in the TRADINVEST group. In the USINVEST group CC was only given to $17 \%$ of the patients. EE was prescribed to $24 \%$ of the patients in the TRADINVEST group. There appeared to be no need for EE in the USINVEST group.

\section{Discussion}

The PC test is a widely used test in the initial stage of the fertility investigation. It has both a diagnostic and a predictive function. The value of the diagnostic function is generally accepted. A positive test implies adequacy of a combination of fertilitydetermining factors. The interpretation of a poor or negative test is more troublesome. In that case the test has to be repeated, particularly if the cervical mucus is suboptimal, since inappropriate timing is the most common cause of a negative test. In the presence of good cervical mucus, however, a poor or negative test requires further investigation or treatment. The prognostic value of the PC test, however, is still controversial. Some authors suggest that couples are as likely to achieve a pregnancy with a negative test as with a positive one: Giner et al. (1974) and Gibor et al. (1970) found no correlation between the result of the PC test and the occurrence of pregnancy. 
Buxton and Southam (1958) and Davajan et al. (1970) found a correlation between the number of spermatozoa per HPF and the occurrence of pregnancy, whereas Jette and Glass (1972) could only substantiate a predictive value of the PC test regarding the eventual occurrence of pregnancy if more than 20 spermatozoa per HPF were observed. Portuondo et al. (1982) and Hull et al. (1982) demonstrated a correlation between the result of the PC test and the occurrence of pregnancy in patients with otherwise unexplained infertility.

In a recent paper, Hull et al. (1984) studied the PC test in relation to the results of in-vitro fertilization and concluded that spermatozoa which were unable to penetrate preovulatory cervical mucus, apparently were also less able to fertilize oocytes. We studied the influence of optimal timing by ultrasound upon the prognostic value of the PC test. We did not apply any selection criteria concerning infertility causes (except for the length of the cycle), because the test is an integral part of the screening period of our standard fertility investigation. Restriction of the study population to patients with unexplained infertility who are known to have an increased overall pregnancy rate (Hull et al., 1984) will artificially improve the prognostic value of a positive PC test (Stempel, 1982).

In our study the groups differed only in the way the PC test was timed. In the TRADINVEST group there was no substantial difference in pregnancy rate between patients with a positive PC test and a negative one. This means that the PC test, performed in a classical way, as a prognostic test may be abolished from the standard fertility investigation.

In the USINVEST group, however, a significant difference was found in the pregnancy rate between patients with a positive $\mathrm{PC}$ test and patients with a negative one. A PC test, performed in this way, is of great use for the standard fertility investigation. Optimal timing reduced considerably the number of false-negative test results. In contrast with all other studies of the value of the PC test, in our study none of the patients in the USINVEST group who would eventually become pregnant, had a negative PC test as the best test. False-negative tests are troublesome. They force to perform unnecessary investigations and/or to initiate possibly counterproductive treatments. It is true that the number of false-positive PC tests was increased in the USINVEST group, but this can readily be explained by other factors of infertility, not tested by the PC test. These factors, however, will be investigated in a later stage of the fertility investigation anyhow, irrespective of the PC test result.

Ultrasound not only increases the value of the PC test, it also increases the efficiency of the fertility investigation. The duration of the screening period was shortened considerably. Wetzels et al. (1982) described the inaccuracy of the BBT in timing the exact moment of ovulation compared with ultrasound. The results of the present investigation indicate that, if in infertility clinics adequate ultrasound equipment is available, there is no need for the BBT anymore in the standard fertility investigation. The average number of ultrasound scans per cycle was rather high, because we applied a rigid protocol $\|_{n}$ as described above. The number of follicle measurements can readily be reduced to an average of 4 per cycle, without interfering with 
the reliability of $\mathrm{PC}$ test timing. Depending on the menstrual history the initial ultrasound investigation of the growing follicle can be delayed. Furthermore, scans can be repeated every 3 days instead of 2 , as long as the follicle has not yet reached a mean diameter of $15 \mathrm{~mm}$. As soon as PC tests are performed on alternating days, also ultrasound scans can be performed in the same frequency.

Ultrasound makes standardization of the fertility investigation possible, which until now, hardlly could be achieved. Consequently, blood sampling for endocrine determinations can be done at fixed intervals during the luteal phase, related to the moment of follicle rupture.

AIH and AID procedures can be timed more accurately using ultrasound (Rönnberg et al., 1978) and according to the results of the present investigation inseminations should be aimed at the day before ultrasound evidence of follicle rupture (Figure II.2). Five out of 10 positive $\mathrm{PC}$ tests on the day before ovulation resulted in a pregnancy, whereas only 1 out of 7 positive PC tests on the day of ovulation resulted in a pregnancy.

When we compared the rates of normal findings in the first examination cycle, we demonstrated that the traditional approach always was underestimating fertility prognosis compared to the ultrasound-guided method, although the overall pregnancy rate after a follow-up of 1 year in both groups was similar (Figure II.1). In the TRADINVEST group a larger number of false-negative results is found. The differences in results between the two groups mainly can be attributed to differences in the accuracy of the methods by which the moment of ovulation was detected. The life table analysis shows that in the TRADINVEST group only $6 \%$ of the patients became pregnant during the first cycle, whereas in the USINVEST group this precentage was $18.3 \%$ (Figure II.1). This again stresses the important role of timing ovulation/coitus in the treatment of subfertile couples.

The need for $\mathrm{CC}$ and $\mathrm{EE}$ to stimulate the hormonal activity in the preovulatory phase and/or to improve the cervical mucus qualities was reduced considerably. Absence of adequate cervical mucus in the periovulatory phase was a rare condition in the USINVEST group. The diagnosis of 'dysmucorrhea' could be established unequivocally, once inadequate mucus qualities were observed in the presence of a preovulatory follicle upon ultrasound examination.

We demonstrated that the PC test, performed in the course of a traditional fertility investigation, failed to have any substantial prognostic value. This questions the relevance of the test in this respect. Timing of the PC test by ultrasound, however, resulted in a valuable, highly specific test. Especially important is the finding that it is possible to reduce the number of false-negative tests to zero.

Furthermore, ultrasound enhanced the reliability and the efficacy of the entire fertility investigation and increased its rate of progress. In our opinion, ultrasound should therefore become an integral part of the standard fertility workup; especially for those patients in whom the traditional investigation in the first examination cycle has yielded a negative PC test result. 


\section{References}

Buxton, C.L., Southam, A.L.: Human infertility.

New York: Hoeber-Harper, 1958

Davajan, V., Nakamura, R.M., Kharma, K.: Spermatozoan transport in cervical mucus.

Obstet Gynecol Surv 25:1, 1970

Gibor, Y., Gancia, C.J., Cohen, M.R.. Scommegna, A.: The cyclical changes in the properties of the cervical mucus and the resullts of the postcoital test.

Fert Steril 21:20, 1970

Ginner, J., Merino, G., Luna, J., Aznar, R.: Evaluation of the Sims-Huhner postcoital test in fertile couples.

Fert Steril 25:145, 1974

Hamilton, C.J.C.M., Wetzels, L.C.G., Evers, J.L.H., Hoogland, H.J., Muytjens, A., de Haan, J.a Follicle growth curves and hormonal patierns in patients with the luteinized unruptured follicle syndrome. Fert Steril $43: 541,1985$

Huhner, M.: Sterility in the male and female and its treatment.

New York: Rebman, 1913

Hull, M.G.R., Savage, P.E., Bromham, D.R.: Prognostic value of the postcoital test: prospective study based on time-specific conception tates.

Br J Obstet Gynaecol 89:299, 1982

Hull, M.G.R., Joyce, D.N., McLeod, F.N., Ray, B.D., McDermott, A.: Human in-vitro fertilisation, in-vivo sperm penetration of cervical mucus, and unexplained infertility.

Lancet in:245, 1984

Jette, N.T., Glass, R.H.: Prognostic value of the postcoital test.

Fent Steril 23:29, 1972

Portuondo, J.A., Echanojaunegui, A.D., Herran, C., Agustin, A.: Prognostic value of postcoital test in unexplained infertility.

Int J Fert 27:184, 1982

Rönnberg, L., Ylöstalo, P., Joupilla, P.: Ultrasound to time insemination.

Lancet i:669, 1978

Roumen, F.J.M.E., Doesburg, W.H., Rolland, R.: Hormonal patterns in infertille women with a deficient postcoital test.

Fert Steri] 38:42, 1982

Sims, J.M.: Clinical notes on uterine surgery.

New York: Wood, 1866

Stempel, L.E.: Eenie, meenie, minie, mo... what do the data really show?

Am J Obstet Gynecol 144:745, 1982

Wetzels, L.C.G., Hoogland, H.J., de Haan, J.: Basal body temperature as a method of ovulation detection: comparison with ultrasonographical findings.

Gynecol Obstet Invest $13: 235,1982$ 



\section{The reliability of ovulation prediction by a single ultra- sonographic follicle measurement}

Hamilton, C.J.C.M., Evers, J.L.H., Tan, F.E.S., Hoogland, H.J. (submitted for publication)

\section{Summary}

Since ultrasonographic ovulation detection has been introduced many authors have speculated about the ovulation predictive value of this new technique. Reliable studies in this respect, however, are lacking.

The present study describes ultrasonographic data of 158 spontaneously ovulating infertile patients. Each patient contributed only one cycle to the study. To construct individual follicle growth curves serial follicular measurements were performed. A wide range existed in maximum mean preovulatory follicle diameters. Furthermore, the slopes of the follicle growth curves, as well as the durations of the follicle growth phases showed considerable variations. The intrinsic variability in the various characteristics of follicle growth makes a single measurement as accurate as serial measurements in predicting ovulation. A formula has been devised by means of the data of the first 100 women, which correlates follicular diameter with the time interval to ovulation. The formula was developed based on one randomly selected mea surement per patient. The validity of the formula has been tested in 58 additional women, also contributing one measurement each. According to this validation the adequacy of the prediction rule was demonstrated.

Ultrasound appeared to be a less sensitive method for prediction of ovulation than has been speculated by some investigators. It is an improvement, anyhow, compared to the prediction of ovulation based upon the length of the previous menstrual cycles. In this view a single follicle measurement may be helpful in timing postcoital tests or artificial inseminations, in addition to being adjuvant to more reliable methods. 
Ovulation prediction is an important issue in the diagnosis and treatment of infertility. In the course of time various methods of ovulation prediction have been proposed. The most reliable method, i.e. the detection of the onset of the $\mathrm{LH}$ surge, requires frequent blood or urine sampling (WHO, 1982). For most clinical purposes, however, less accurate methods of ovulation prediction will be sufficient. Postcoital tests, for example, or artificial inseminations are usually timed by means of the calendar method, based upon the length of previous menstrual cycles. It can be combined with examination of cervical mucus characteristics. The basal body temperature chart can be applied to check, retrospectivelly, whether this timing was correct. In a regular menstrual cycle the day of ovulation can be predicted within a range of 4 to 5 days (Mclntosh et al, 1980). With increasing variability in cycle length the accuracy of ovulation prediction decreases. Cyclic changes in cervical mucus are too inconsistent to be used as a reliable method of ovulation prediction (Baird, 1983). Soon after the introduction of ultrasound as a method of ovulation detection, the expectations of the predictive value of this new technique ran very high. According to Bryce and coworkers (1982) the predictive value of ultrasound would be even better than daily determinations of serum LH or 17- $\beta$-estradiol. Queenan and coworkers (1980), on the other hand, concluded from their study, that the wide range in maximum mean preovulatory follicle diameter precludes the use of ultrasound as a single parameter for prediction of ovulation.

Additional ultrasonographic signs like the appearance of the "cumulus oophorus", (Hackelöer and Robinson, 1978) or the separation of the granulosa wall from the thecal layer have been suggested parameters of follicle maturity (Picker et al., 1983). Also the ultrasonographic aspect of the endometrium has been mentioned in this context (Hackelöer, 1984), although further research will be required to confirm its significance. Those authors who believe in the reliability of ultrasound to predict the moment of ovulation, as well as those who doubt its reliability in this respect, base their conclusions on the investigation of rather small numbers of patients. Furthermore, most investigators have made the mistake to think that ovulation can be predicted on the basis of the range in follicle size at various intervals to ovulation. In this paper we have studied the value of diagnostic ultrasound with regard to ovulation prediction by calculating the time interval to ovulation at various follicular sizes.

\section{Methods}

Daily ultrasonographic follicle measurements were performed during the late follicular phase in 158 successive patients with a spontaneous ovulatory cycle, attending 
the fertility clinic at the university hospital, Academisch Ziekenhuis Maastricht, the Netherlands. We prefered to use an infertility population instead of a normal population, because ovulation prediction is usually applied in an infertility practice. 122 patients had a history of primary infertility, 36 patients had a history of secondary infertility. The age of the patients was $28.8 \pm 4.5$ years (mean \pm SD).

The total number of scans was 671 , with a mean of 4.2 scans per cycle. Follicle measurements less than $14 \mathrm{~mm}$ were discarded. Table III. I shows the distribution of the number of measurements per cycle.

The mean follicular diameter was calculated as the mean of three perpendicular measurements, as reported earlier (Hamilton et al., 1985). The follicle growth phase was defined in the present study as the interval between the moment a follicular diameter of $14 \mathrm{~mm}$ was found and the moment of ovulation.

The dominant follicle was localized using a real time sector scanner (Emisonic NE 4264, Nuclear Enterprise Ltd., Edinburgh, Scotland). The follicle measurements were performed using a compound B-mode scanner (Emisonic NE 4201, Nuclear Enterprise Ltd., Edinburgh, Scotland). Evidence of ovulation was given by ultrasonographic signs of follicle rupture (Hamilton et al., 1985) and confirmed by a rise in serum progesterone level.

The actual moment of ovulation was approximated by the ultrasonographic ovulation time (UOT), which is defined as the midpoint of the time interval between the last follicle measurement and the first moment ultrasonographic signs of ovulation were obtained. The maximum interval between two measurements was 24 hours. The maximum deviation between UOT and the actual moment of ovulation, therefore, was 12 hours.

In cycles with at least 5 measurements the Pearson correlation coefficient was calculated between the follicular diameter and the interval passed since the onset of the last menstruation. The Pearson coefficient varied from 0.92 to 0.99 . Hence, follicle growth is linear in the last five days before ovulation. Therefore, the slope of the individual follicle growth curves can be calculated by constructing regression lines based on the various follicle measurements. In order to calculate the slopes the interval passed since the onset of the last menstruation was expressed in hours and the follicle size in tenth of millimeters.

A prediction rule, correlating the follicular diameter with the time intervall to owulation, has been devised by means of the data of the first 100 patients. Only one randomly selected measurement per patient was used. The time interval to ovulation can never be negative. This restriction is unattractive in statistical procedures. By taking the natural logarithm, however, the range of the time interval becomes unrestricted. Furthermore, after transformation the skewness in distribution disappears, and resembles a normal distribution.

The prediction intervals for various follicular diameters, i.e. the calculated windows of time in which ovulation will take place, were calculated according to Miller (1981). The prediction intervals, also called tolerance bands, are in fact population percentiles. The prediction interval between the $P$ th and (100-P)th percentile covers 


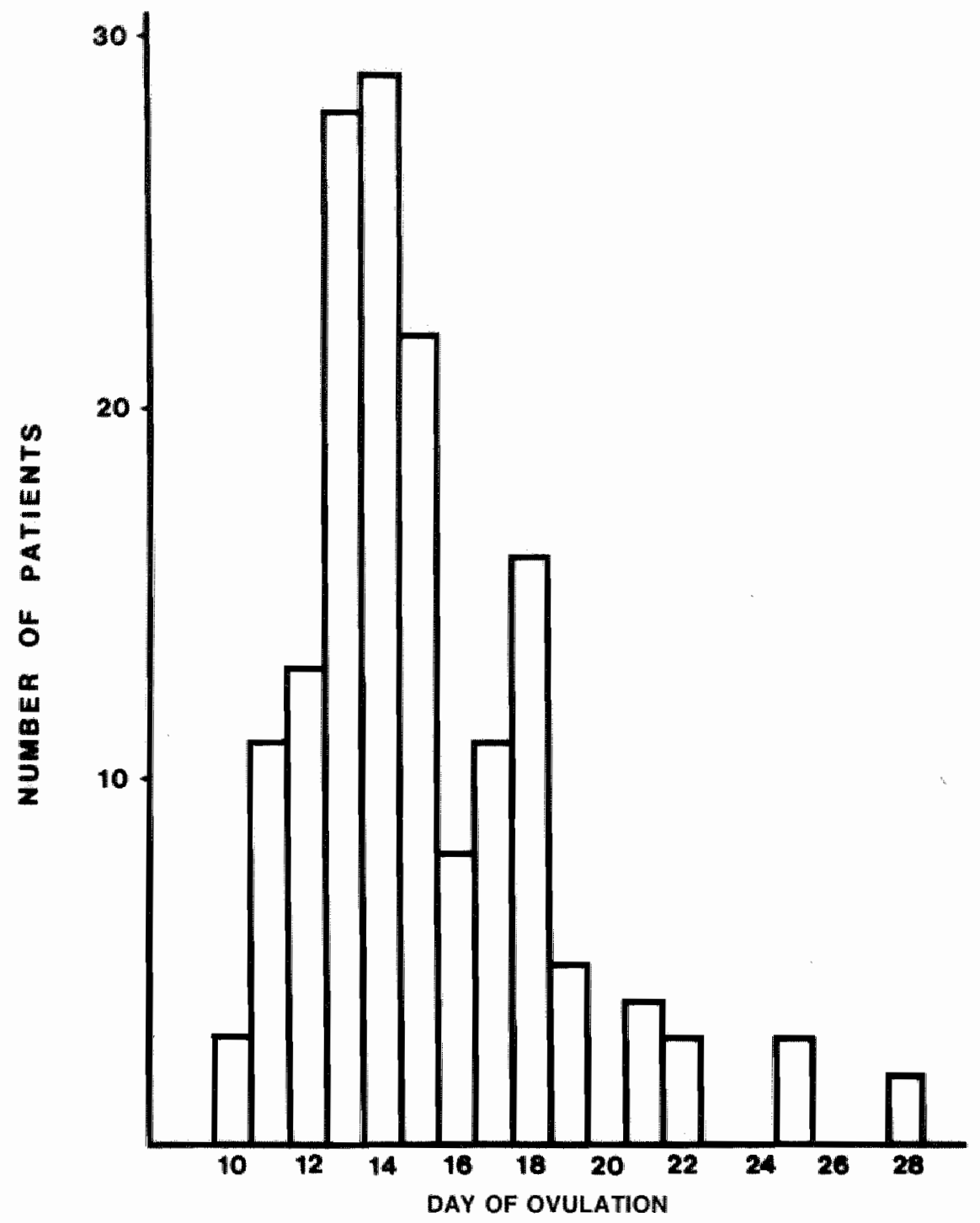

Figure III.I

Frequency distribution of the day of the cycle on which ovulation took place in 158 sponianeous menstrual cycles of 158 infertility patients.

a fraction of $(100-2 \mathrm{P})$ percent of the actual time intervals to ovulation of the population. (100-2P) percent of all future measurements are enclosed in this interval. In reality, however, prediction intervals are constructed by means of estimations, based on sample data. The various estimated tolerance bands, are subject to sampling errors. Following the procedure proposed by Miller, it is possible to control the overall reliability of the estimated fraction of the population enclosed in the chosen 


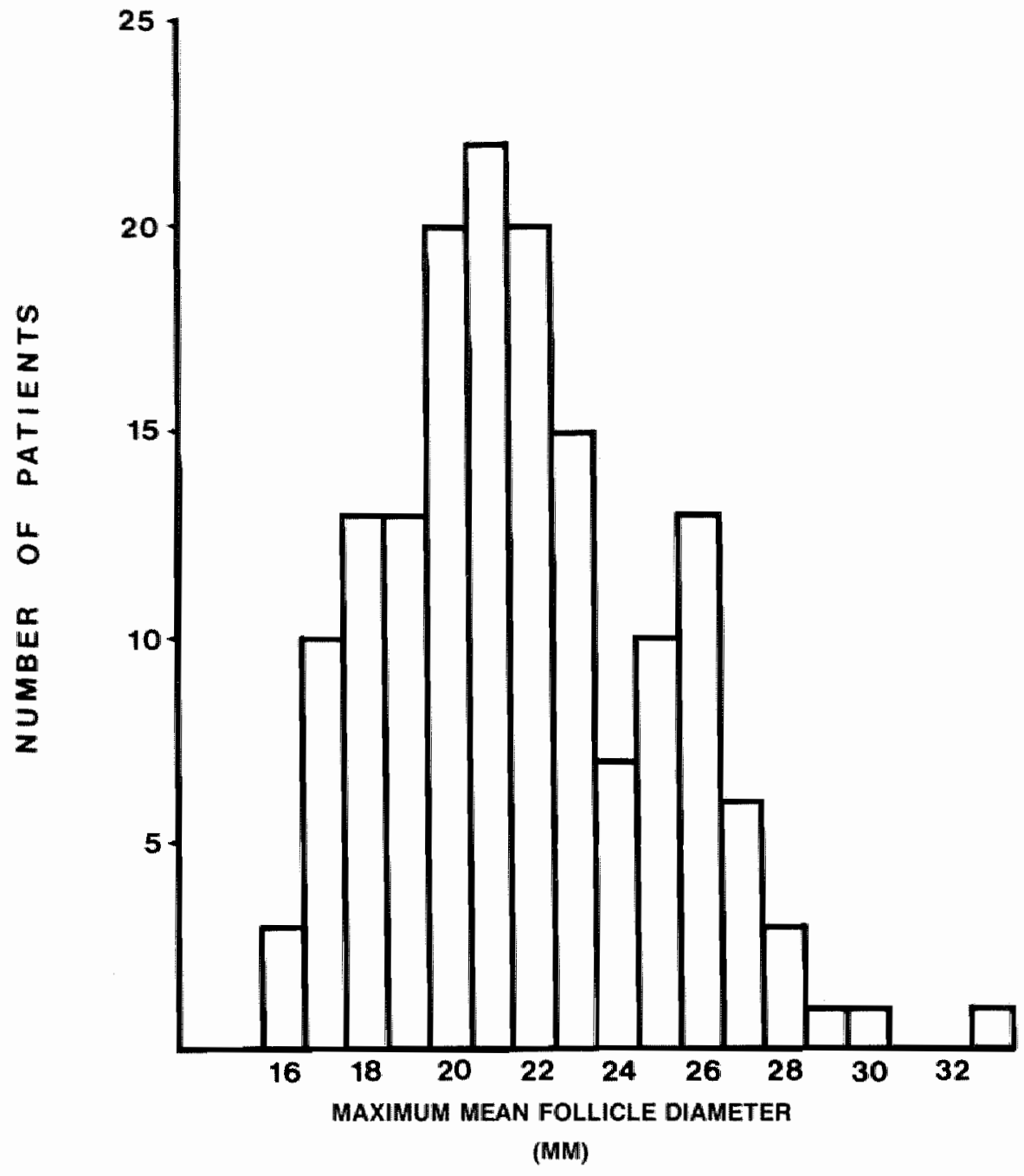

Figure III.2

Frequency distribution of the maximum mean preovulatory follicle diameter in 158 spontaneous menstrual cycles of 158 infertility patients.

interval. In the present study the overall reliability is set at $95 \%$. The prediction interval we chose, was the interval between the 10th and 90th percentiles.

To validate the prediction rule, the constructed prediction intervals were tested in a second sample of 58 different patients. Again, only one randomly selected measurement per woman from this second sample was used for validation. 


\section{Results}

Figure III.1 shows the frequency distribution of the day of ovulation (UOT) with respect to the day of the last menstrual period in the complete study group of 158 patients.(Mean day $\pm \mathrm{SD}: 15.1 \pm 3.3$; range: day 10 - day 28 )

Figure III. 2 shows the frequency distribution of the maximum mean preovulatory follicle diameter. The average ( \pm SD) maximum mean follicular diameter was 21.8 $\pm 3.2 \mathrm{~mm}$ (range: $16-33 \mathrm{~mm}$ ).

Tabel III.I

Distribution of the number of ultrasonographic measurements per cycle.

\begin{tabular}{cc}
$\begin{array}{c}\text { Number of scans } \\
\text { per cycle }\end{array}$ & Number of cycles \\
\hline 2 & 15 \\
3 & 42 \\
4 & 37 \\
5 & 32 \\
6 & 20 \\
7 & 10 \\
8 & 1 \\
9 & 1 \\
\hline
\end{tabular}

Table III.2

Frequency distribution of the slope of the individual follicte growth curves and the corresponding average maximum mean preovulatory follicle diameters $(r=0.39)$ and the corresponding average vime intervals to ovulation based on an arbitrarily chosen follicle size of $17 \mathrm{~mm}(p=-0.29)$.

\begin{tabular}{cccc}
\hline Slope & $\begin{array}{c}\text { Average maximum mean } \\
\text { preovulatory follicle } \\
\text { diameter }( \pm \text { S.D.) } \\
\text { in mm. }\end{array}$ & $N$ & $\begin{array}{c}\text { Average time interval } \\
\text { to ovulation } \pm \text { S.D.) } \\
\text { in hours }\end{array}$ \\
\hline $0.2-0.3$ & 17 & 1 & 10 \\
$0.3-0.4$ & $20.3 \pm 2.6$ & 7 & $117.7 \pm 45.8$ \\
$0.4-0.5$ & $19.9 \pm 2.0$ & 10 & $82.4 \pm 27.4$ \\
$0.5-0.6$ & $20.6 \pm 2.6$ & 19 & $65.0 \pm 48.0$ \\
0.640 .7 & $22.2 \pm 2.7$ & 24 & $92.6 \pm 44.0$ \\
$0.7-0.8$ & $22.6 \pm 3.0$ & 16 & $77.0 \pm 37.5$ \\
$0.8-0.9$ & $22.0 \pm 2.8$ & 27 & $74.5 \pm 33.0$ \\
$0.9-1.0$ & $22.2 \pm 3.3$ & 22 & $71.9 \pm 35.7$ \\
$1.0-1.1$ & $23.8 \pm 3.1$ & 13 & $71.6 \pm 31.6$ \\
1.1 .1 .2 & $22.5 \pm 2.6$ & 8 & $60.4 \pm 21.5$ \\
$1.2-1.3$ & 27 & 1 & 96 \\
$1.3-1.4$ & $25.3 \pm 5.7$ & 4 & $65.8 \pm 30.8$ \\
$1.4-1.5$ & 18 & 1 & 17 \\
$1.5-1.6$ & 25 & 1 & 76 \\
$1.6-1.7$ & - & -1 & - \\
$1.7-1.8$ & 20 & 3 & 26 \\
0 Ovulated & - & 158 & - \\
\hline
\end{tabular}


Lineaür regression model to explain the wariation in time imterval to ovulation (TrTo) in hours in relation to the mean follicle diameter $(D)$ in mm.

a and b are regression parameters. $e$ is the normally distributed residuat with mean gero and estimated residual standard dewiation $s(s=0.53)$. e is a measure of the difference between the predicted and the actually measured time interval to ovulation.

\begin{tabular}{c}
$\ln ($ TITO $)=\mathrm{a}+\mathrm{bD}+\mathrm{e}$ \\
\hline $\mathrm{a}=2.21 \pm 0.3$ \\
$\mathrm{~b}=-0.83 \pm 0.16$ \\
$\mathrm{e}=0 \pm 0.53$ \\
\hline
\end{tabular}

Table III.4

The different percentiles (in days) of the prediction interval, wh which ovulation will take place, arranged according to the various mean follicle diameters.

\begin{tabular}{|c|c|c|c|c|c|}
\hline $\begin{array}{l}\text { Mean follicle } \\
\text { diameter } \\
\text { (in } \mathrm{mm} \text { ) }\end{array}$ & 10th & 25 th & $\begin{array}{l}\text { 50th } \\
\text { tiles (i) }\end{array}$ & 75th & 90th \\
\hline 14 & $11 / 4$ & $11 / 2$ & $23 / 4$ & $51 / 4$ & 7 \\
\hline 15 & 1 & $11 / 2$ & $2^{3 / 4}$ & $43 / 4$ & $6 \%$ \\
\hline 16 & $\mathbb{1}$ & $11 / 2$ & $2 x$ & 4 & $51 / 2$ \\
\hline 17 & 1 & $11 / 4$ & $21 / 2$ & $33 / 4$ & 5 \\
\hline 18 & 1 & $1^{11 / 4}$ & 2 & $3 \% / 4$ & $4 / 2$ \\
\hline 19 & 1 & $11 / 4$ & 2 & 3 & 4 \\
\hline 20 & $3 / 4$ & 1 & $13 / 4$ & $23 / 4$ & $3 z / 4$ \\
\hline 211 & $3 / 4$ & 1 & 10,2 & $2 y / 2$ & $31 / 4$ \\
\hline 22 & $3 / 4$ & 1 & $11 / 2$ & $2^{1 / 4}$ & $31 / 4$ \\
\hline 23 & $1 / 2$ & $3 / 4$ & $11 / 4$ & $21 / 4$ & $23 / 4$ \\
\hline 24 & $1 / 2$ & $3 / 4$ & $1 / 4$ & 2 & $23 / 4$ \\
\hline 25 & $1 / 2$ & $3 / 4$ & $1 \% / 4$ & 2 & $23 / 4$ \\
\hline
\end{tabular}

As can be deduced from the number of scans per cycle (Table III.1), a wide range existed in the duration of follicle growth phases (2-9 days). A considerable variation could also be found in the slopes of the growth curves (Table III.2). With increasing slope the average maximum mean follicle diameter increased $(r=0.39)$. Hence, the faster the follicles grew, the larger they tended to become. The average time interval to ovulation, as calculated for follicles of $17 \mathrm{~mm}$ in size, decreased only slightly with increasing slope $(r=-0.29)$. Moreover the considerable intraobserver variation of follicle measurements precludes exact calculation of the slope (Eissa et al., 1985). The slope, therefore, hardly supplies any additional information for ovulation prediction. In clinical practice a single ultrasonographic measurement is as accurate as serial measurements in predicting ovulation.

Table III.3 shows the prediction formula, based on a single measurement per patient, correlating follicular diameter with the time interval to ovulation. Also the fitted values of the regression parameters in the formula are given. Only $22 \%$ of the 


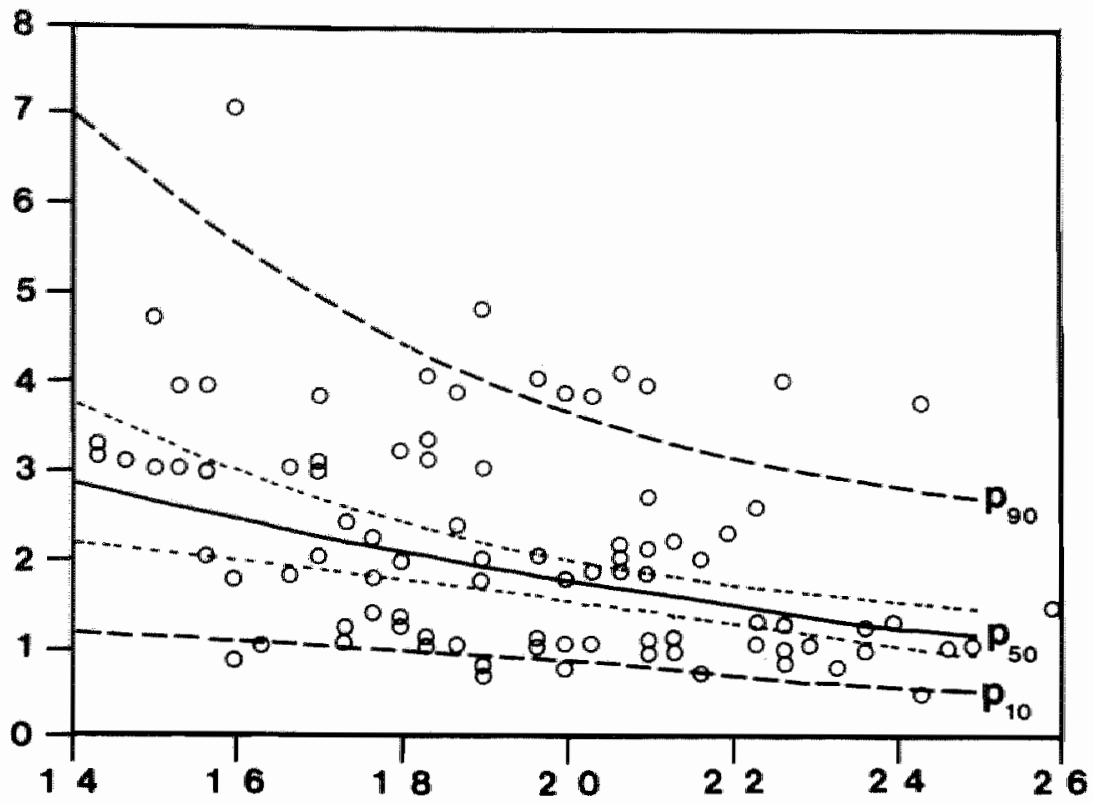

\section{MEAN FOLLICLE DIAMETER}

\section{$(\mathrm{mm})$}

Figure $11 \mathrm{I} .3$

100 randomly selected ultrasonographic measurements of 100 infertility patients, having a spontaneous ovulatory cycle (circles). Note that some data points have been superimposed. The estimated $10 \mathrm{th}, 50 \mathrm{th}$ and $90 \mathrm{th}$ percentile lines of the population are indicated. The thinly dotted lines around the 50th percentile line represent the reliability range with which this line was constructed.

variance in the natural logarithm of the time interval to ovulation is explained by the relation between the time interval to ovulation and the follicle diameter. Figure III.3 shows the 100 randomly selected measurements of the first 100 patients. Note that some data points have been superimposed. Also the 10th, 50th and 90 th percentile lines of the predicted time interval to ovulation for increasing follicular diameters are given. Table III.4 gives some additional information in figures.

Application of the prediction rule on a second sample of 58 different patients, showed that $91.4 \%$ was covered by the area between the 10 th and 90 th percentiles. $5.2 \%$ ( 3 out of 58 patients) lay above the 90 th percentile and $3.4 \%$ ( 2 out of 58 patients) lay below the 10th percentile. This indicates the adequacy of the constructed prediction rule. 


\section{Discussion}

Several important conclusions can be drawn from this study.

First, a larger number of measurements per cycle does not improve the predictive value of a single ultrasound follicle measurement.

Second, the mere presence of a follicle with a mean diameter of more than $14 \mathrm{~mm}$ has predictive value, independent of the actual follicle size. Ovulation will take place between $11 / 4$ and 7 days later in $80 \%$ of patients. Especially in patients with an irregular menstrual cycle, ultrasound can be useful to detect the potential fertile period. If no dominant follicle is visible, ultrasound scans can be repeated every 3 or 4 days, until a growing follicle is demonstrated, or, considering the day of the cycle, until the probability, that the cycle will remain anovulatory, is high.

Third, accurate measurement of follicles, larger than $14 \mathrm{~mm}$, will enhance the predictive value: the calculated window of time in which ovulation will take place, i.e. the prediction interval (21/4-53/4 days) is smaller than can be deduced from the length of previous cycles (4-11 days) (Mclntosh et al., 1980).

\section{Table III.5}

Advised time to perform artificial inseminations or postcoital tests according to the mean follicle diameter recorded.

\begin{tabular}{cc}
\hline $\begin{array}{c}\text { Mean follicle } \\
\text { diameter } \\
(\mathrm{mm})\end{array}$ & $\begin{array}{c}\text { Advised time for } \\
\text { artificial insemination } \\
\text { or postcoital test }\end{array}$ \\
\hline $14-16$ & 1,3 and 5 days later \\
$17-20$ & $\begin{array}{l}1 \text { and } 3 \text { days later } \\
0 \text { and } 2 \text { days later }\end{array}$ \\
\hline
\end{tabular}

Notwithstanding the fact that we have demonstrated that the real predictive value of ultrasound is considerably less than suggested before (Bryce et al., 1982), for several clinical purposes this predictive value is adequate. Table III.5 shows the advised moments at which procedures like postcoital tests or artificial inseminations are to be performed preferably, accordling to the recorded follicle diameter, and taking into account the timespan of the fertilizing capacity of sperm (Royston, 1980). Ultrasound can also indicate the time to start more reliable, but also more cumbersome and expensive ovulation predictive procedures, like serial urine or serial serum $\mathrm{LH}$ determinations.

In this study we evaluated the predictive value of diagnostic ultrasound with regard to the moment of ovulation. We conclude, that the predictive value of ultrasound is only limited. It can not be improved considerably by increasing the number of ultrasonographic scans. Yet the predictive value of a single follicular measurement is superior to be ovulation prediction based on the menstrual history. It is sufficient- 
ly accurate to time routine clinical procedures like postcoital tests and artificial inseminations. If more accurate prediction of the moment of ovulation is required, one should revert to serial $\mathrm{LH}$ determinations.

\section{References}

Baird, D.T.: Prediction of owulation: biophysical, physiological and biochemical coordinates. In: Ovulation: methods for its prediction and detection. Ed. Jeffcoate SL, Chichester: John Willey \& Sons Lid pp $1-17,1983$

Bryce, R.L., Shuter, B., Sinosich, M.J., Stiel, J.N., Picker, R.H., Saunders, D.M.: The value of ultra* sound, gonadotropin, and estradiol measurements for precise ovulation prediction.

Fertil Sterii $37: 42,1982$

Eissa, M.K., Hudson, K., Docker, M.F., Sawers, R.S., Newton, J.R.: Ultrasound follicle measurement: an assessment of interobserver and intraobserver variation.

Fertil Steril 44:751, 1985

Hackelöer, B.J., Robinson, H.P.: Uttraschalldarstellung des wachsenden Follikels und Corpus Luteum im normallen physiologischen Zyklus.

Geburtshilfe Frauenheilkd 38:163, 1978

Hackelöer, B.y.: The role of ultrasound in female inferility management.

Ultrasound Med Biol 10:35, 1984

Hamilton, C.J.C.M., Wetzels, L.C.G., Evers, J.L.H., Hoogland, H.J., Muytjens, A., de Haan, J.: Follicle growth curves and hormonal patterns in patients with the luteinized unruptured follicle syndrome. Fertil Sterill 43:541, 1985

McIntosh, J.E.A., Matthews, C.D., Crocker, J.M., Broom, T.J., Cox, L.W.: Predicting the luteinizing hormone surge: relationship between the duration of the follicular and luteal phases and the length of the human menstrual cycle.

Fertil Steril $34: 125,1980$

Miller, R.G. jr.: Regression technique.

In: Simultaneous statistical inference, second edition. Ed. Miller RG jr., New York: Springer Verlag, pp $109-128,1981$

Picker, R.H., Smith, D.H., Tueker, M.H., Saunders, D.M.: Ultrasonic signs of imminent ovullation. J Clin Ultrasound 11:1, 1983

Queenan, J.T., O'Brien, G.D., Bains, L.M., Shmpson, J., Collins, W.P., Campbell, S.: Ultrasound scanning of ovaries to detect ovulation in women.

Fertil Sterill $34: 99,1980$

Royston, J.P.: Basal body temperature, ovulation and the risk of conception with special reference to the lifetimes of sperm and ege.

Biometrics 38:397, 1980

WHO task Force on methods for the determination of the fertile period: Temporal relationships between ovulation and defined changes in the concentration of plasma estradiol-17-b, luteinizing hormone, follicle stimulating hormone and progesterone. 1. Probit analysis.

Am J Obstet Gynecol 138:383, 1980 
Follicle growth curves and hormonal patterns in patients with the luteinized unruptured follicle syndrome

Hamilton, C.J.C.M., Wetzels, L.C.G., Evers, J.L.H., Hoogland, H.J., Muijtjens, A., de Haan, J.

(Fertility and Sterility 43:541, 1985)

(with permission)

\section{Summary}

A prospective longitudinal and standardized study is presented, dealing with ultrasonographical and hormonal characteristics of the luteinized unruptured follicle (LUF) syndrome. Among 600 cycles monitored in 270 infertility patients, 40 cycles in 27 patients showed no evidence of follicle rupture, in spite of signs of luteinization, as reflected by basal body temperature recordings and progesterone determinations. In this study, 20 LUF cycles in 20 infertile patients were compared with 45 ovulatory cycles in 45 control women. During the follicular phase, no substantial difference in follicle growth was found, but after the luteinizing hormone peak, LUF follicles, instead of rupturing, showed a typical accelerated growth pattern. Both mean luteinizing hormone peak levels and midluteal progesterone levels were significantly lower in LUF cycles than in the control cycles. However, the duration of the luteal phase was not affected. Both central and local factors can be held responsible for the lack of follicle rupture. Ultrasound offers new possibilities as a noninvasive method in diagnosing the LUF syndrome. 


\section{Introduction}

Since Jewelewicz in 1975 first described the luteinization of an unruptured follicle (LUF) as a distinctive entity among menstrual cycle disturbances, clinical evidence for the importance of this LUF syndrome as a cause of female infertility has been given by various groups of investigators (Marik and Hulka, 1978; Koninckx et al., 1978; Koninckx et al., 1980a). The absence of an ovulation stigma in the early luteal phase of the cycle in combination with low peritoneal fluid (PF) concentrations of progesterone $(\mathrm{P})$ and $17-\beta$-estradiol $\left(\mathrm{E}_{2}\right)$ characterize this syndrome (Koninckx et al., 1980a; Donnez et al., 1983). Using classical criteria, basal body temperature and serum P, LUF cycles cannot be distinguished from ovulatory cycles. Both the observation of a stigma and the collection of PF require invasive procedures. Rapid reepithelialization of the stigma may occur. This can give an explanation for the sometimes high frequency of apparently incorrect or even failed recognition of an ovulation stigma, even by experienced laparoscopists (Koninckx et al.,1980a; Vanrell et al., 1982; Portuondo et al., 1983; Liukkonen et al., 1984). Moreover, a considerable overlap in PF steroid concentrations exists between patients with and without a stigma (Koninckx et al., 1980a).

To investigate the incidence and the recurrence rate of the LUF syndrome a need exists for a method which enables repeated observations in the same patient in a noninvasive way. We applied ultrasonography to study follicle growth in relation to hormonal changes during the menstrual cycle in a prospective, longitudinal study of patients with the LUF syndrome and compared the results with those obtained in a control group of women with normal ovulatory cycles.

\section{Materials and methods}

Since the introduction of ultrasonography in our infertility clinics in 1981 , we have studied 600 cycles in 270 patients, applying a well-defined, prospective schedule. Ultrasound observations started on day eight of the cycle and were repeated every other day until the dominant follicle had reached a mean diameter of $15 \mathrm{~mm}$. From then on, daily ultrasound scans were performed. Ovulation was defined as a decrease in mean follicular diameter. It resulted in complete disappearance of the follicle or in reduction of its volume, with thickening of the follicle wall, or in replacement of the follicle by an area of spongy appearance (Wetzels and Hoogland, 1982). If ovulation occurred, a final ultrasound examination was performed after seven days to study the aspect of the corpus luteum in the midluteal phase of the cycle. In case the follicle did not rupture, daily scanning was continued up to three days after the largest follicle had reached a diameter of $30 \mathrm{~mm}$, or until the dominant 
follicle did not grow any further for three successive days. Further scans were performed at 3-day intervals during the luteal phase.

All ovarian ultrasound investigations were performed using a real-time mechanical sector scanner (Emisonic NE 4264, Nuclear Enterprises Ltd., Edinburgh, Scotland) and a static compound B-mode scanner (Emisonic NE 4201, Nuclear Enterprises Ltd.) calibrated at a sound velocity of $1540 \mathrm{~m} / \mathrm{second}$. The real-time sector scanner was only used to localize the ovary containing the dominant follicle. The best results were obtained with a $3.5-\mathrm{MHz}$ transducer. A rigid standardization protocol for follicle measurements was applied to enable reproducible measurements: the follicles were scanned in a transverse and in a sagittal plane referring to the body axis. In the transverse plane, the largest diameter of the follicle and the diameter perpendicular to this one were measured. In the parasagittal plane, the largest diameter parallel to the bladder wall was determined. From these three diameters the mean diameter of the follicle was calculated. The relative error of the follicle measurements was $2.55 \% \pm 2.26 \%$ (mean $\pm \mathrm{SD}$ ) (Wetzels, 1983). All ultrasound measurements were carried out by one investigator (C.H.). On each occasion an ultrasound scan was performed, also a blood sample was drawn for hormonal analysis. The blood was allowed to clot at room temperature, centrifuged at $1200 \times \mathrm{g}$, and stored at $-20{ }^{\circ} \mathrm{C}$ until assayed. All hormone determinations were performed in triplicate with validated commercially available radioimmunoassay techniques. Luteinizing hormone (LH) was determined by a double-antibody solid-phase kit (National Institute for Radio Elements, Fleurus, Belgium), as were $\mathrm{E}_{2}$ (Institut für Reactorforschung, Würenlingen, Switzerland) and $\mathbf{P}$, following extraction (Farmos Diagnostica, Turku, Finland).

The intraassay and interassay coefficients of variation for $\mathrm{LH}$ were $5.0 \%$ and $8.7 \%$ at the level of $49.1 \mathrm{IU} / \mathrm{l}$. Those for $\mathrm{E}_{2}$ were $8.0 \%$ and $9.8 \%$ at the level of 1.10 $\mathrm{nmol} / \mathrm{l}$, and those for $\mathrm{P}$ were $3.4 \%$ and $4.9 \%$ at the level of $11.1 \mathrm{nmol} / \mathrm{l}$. Estimations of the 5 th, 50th and 95 th percentile of the hormone concentrations were calculated after logarithmic transformation. This procedure of calculation was applied because of their log normal distribution in the normal menstrual cycle (Kletzky et al., 1975). Differences between groups of curves were tested by the one-way analysis of variance for response curves as described by Zerbe (1979). The Wilcoxon rank sum test was used to test for differences in hormone concentrations on individual days (two-tailed levels of significance are given).

In the entire group of 600 cycles in 270 patients investigated, 40 cycles in 27 patients showed no evidence of follicle rupture, in spite of signs of luteinization, as reflected by basal body temperature recordings and $P$ determinations. The clinical data of these patients are summarized in Table IV.1. Only the first LUF cycle in each patient was used for this study. In seven patients the results of hormonal determinations were incomplete. Thus, 20 LUF cycles in 20 patients were eventually used in the present investigation. The follicle growth curves and hormone patterns in these patients were compared with those in 45 spontaneous ovulatory cycles in 45 control women. This control group consisted of 20 healthy female volunteers of proven fertility and 


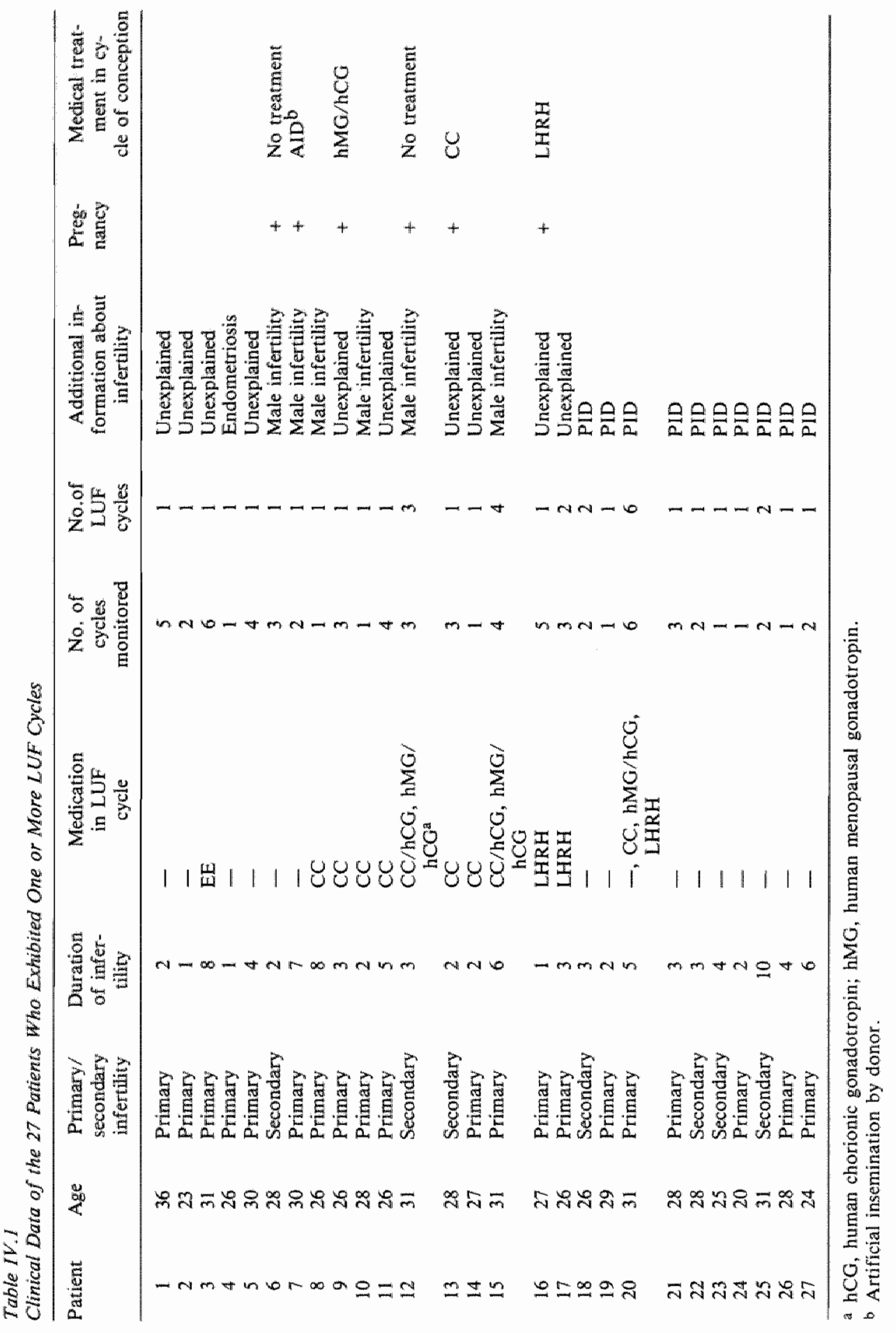




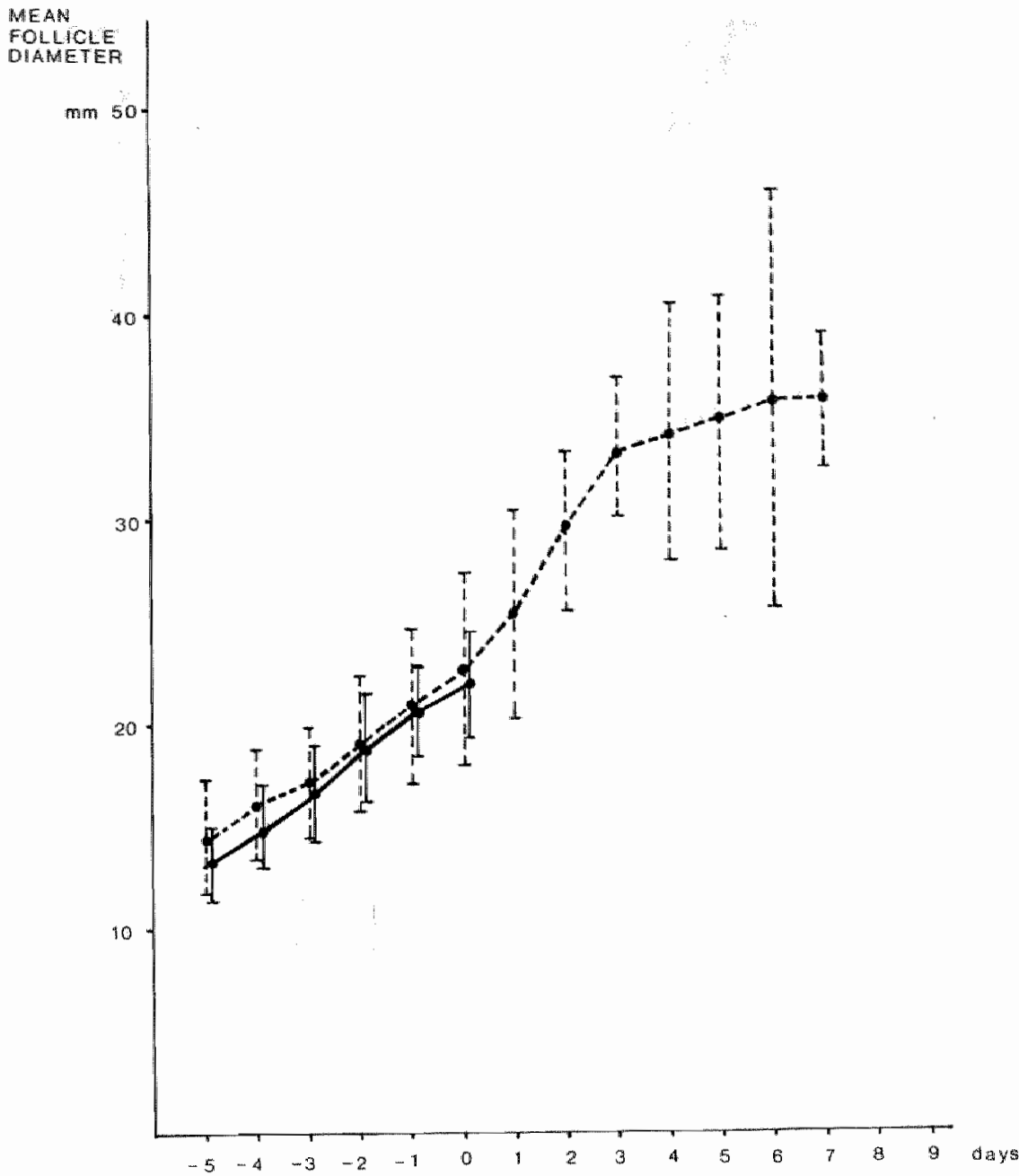

Figure IV.l

Follicle growth carves (mean \pm SD) in 45 spontaneous ovulatory cycles of 45 control women (solid line) and in 20 LUF cycles of 20 infertility patients (broken line).

of 25 patients who were treated by artificial insemination and in whom a complete fertility workup had revealed only a male factor as the cause of the infertility. In three patients with an ultrasonographically detected LUF syndrome, PF was collected in order to determine the steroid content. In two patients this occurred by means of culdocentesis. In one patient PF was aspirated during laparoscopy. These PF aspirations were performed on the third day after the expected day of ovulation. 




Figure IV.2

Serial pictures of the follicular development during one LUF cycle. White numerals indicate the day of the cycle; $\mathrm{M}$ indicates the first day of menstrual bleeding.

\section{Results}

Figure IV. 1 shows the combined follicle growth curve (mean \pm SD) of 45 ovulatory cycles in 45 normal women. All data are arranged according to the day of the LH peak (day 0 ). The follicle growth curve appeared to be linear in the last 5 days before follicle rupture. Also in Figure IV.1, the combined follicle growth curve (mean \pm SD) of 20 unruptured follicle cycles in 20 patients is shown. Until the day of the LH peak there is no substantial difference in follicle growth, compared with the normal growth curve. But after the LH peak, a rapid increase in follicle size is recorded in the LUF cycles. No rupturing of the follicle occurs in these cycles, and the follicle size levels off at a mean diameter of $35.5 \mathrm{~mm}$ (range: 29 to $70 \mathrm{~mm}$ ). This size persists until the end of the cycle in most patients. The cysts subsequently disappear gradual- 


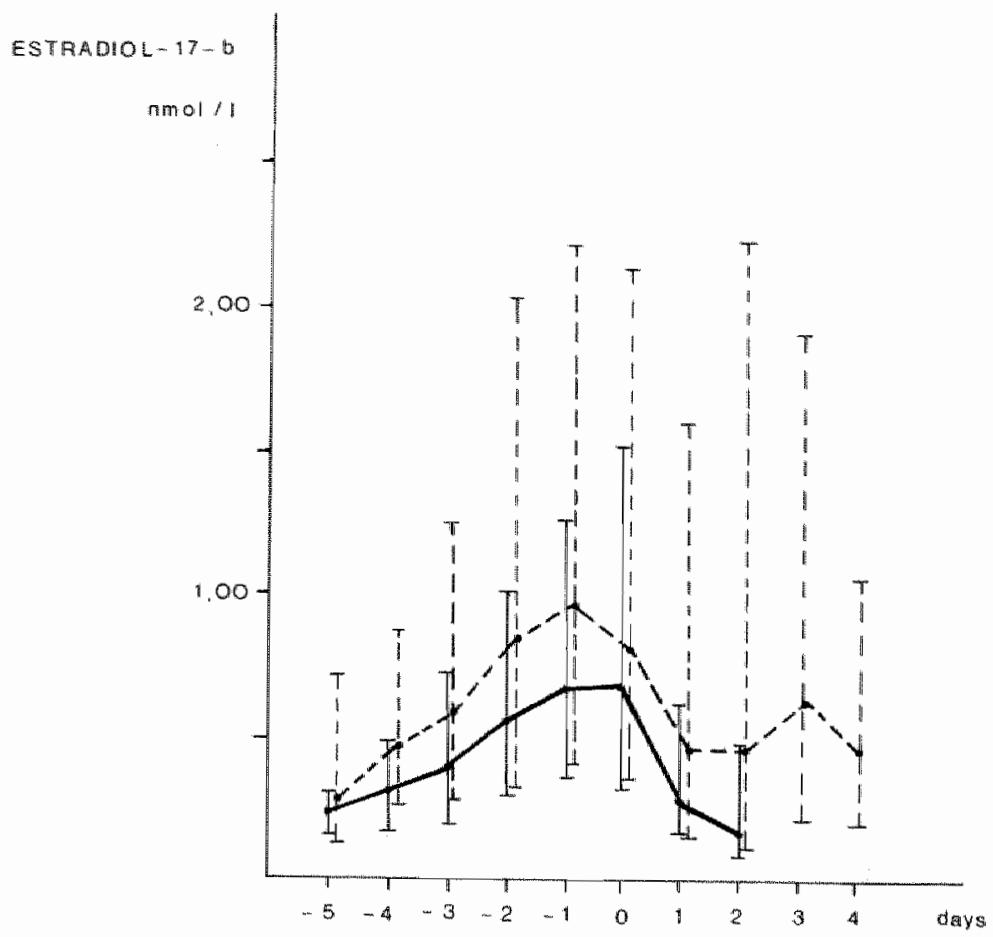

Figure IV.3

Estimated 5 th, 50th, and 95 th percentiles of serum $E_{2}$ levels in 45 spontaneous cycles of 45 control women (solid line) and in 20 LUF cycles of 20 infertility patients (broken line).

ly. Abdominal discomfort was experienced by some patients, but usually the symptoms were minimal, considering the size of the cysts. Figure IV.2 shows the serial ultrasonographic pictures of the follicular development during one cycle in one patient. Figure IV. 3 to 5 show the estimated 5 th, 50 th and 95 th percentile of the hormonal serum levels in the ovulatory and in the unruptured follicle cycles. $\mathrm{E}_{2}$ levels are significantly higher during the follicular phase in the LUF cycles, compared with the ovulatory cycles $(\mathrm{p}<0.05$ for the interval day -3 to day +1$)$.

The LH peak concentrations are significantly lower in the LUF cycles, compared with the ovulatory cycles $(\mathrm{p}<0.01)$. The serum $\mathrm{P}$ levels are higher in the $\mathbb{L}$ UF cycles during the interval day 0 to day $+1(p<0.05)$. The midluteal $P$ levels are significantly lower in the LUF cycles than in the ovulatory cycles $(\mathrm{p}<0.01)$. The $\mathrm{P}$ concentrations in the PF of the three patients who underwent a laparoscopy or a culdocentesis were 38,46 and $71 \mathrm{nmol} / \mathrm{l}(12.0,14.5$, and $22.2 \mathrm{ng} / \mathrm{ml})$; the $\mathrm{E}_{2}$ concentrations were $0.64,0.95$, and $2.60 \mathrm{nmol} / 1(171,250$, and $708 \mathrm{pg} / \mathrm{ml})$, respectively. All these concentrations meet the requirements of Koninckx and co-workers (1980a) for the diagnosis of the LUF syndrome $\left(<80 \mathrm{ng} / \mathrm{ml}\right.$ for $\mathrm{P}$ and $<750 \mathrm{pg} / \mathrm{ml}$ for $\mathrm{E}_{2}$ ). The LH peak in the unruptured follicle cycles occurred, on the average, 2.3 days 


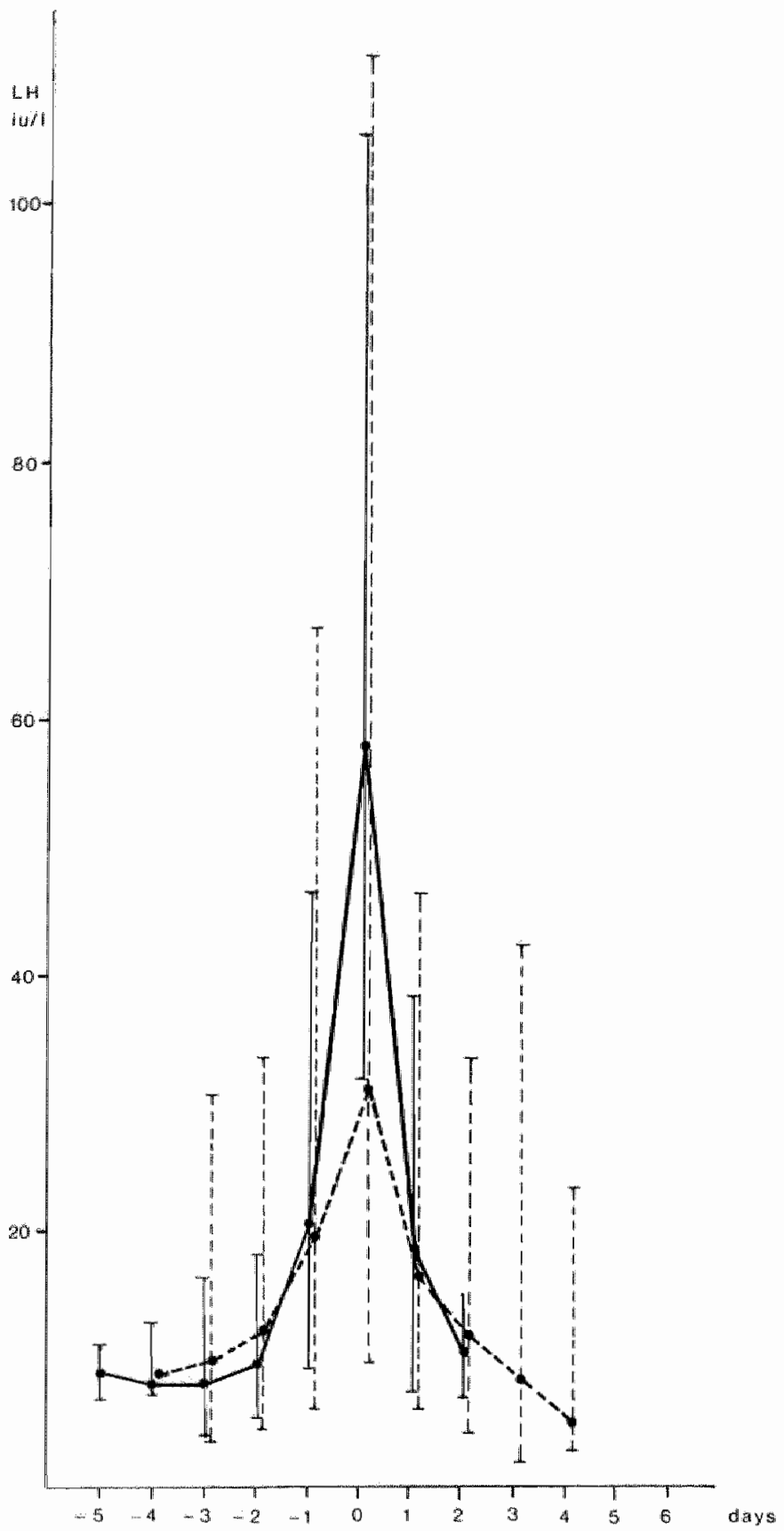

figure IV.4

Estimated $5 t h, 50 t h$, and 95 th percentiles of serum LH levels in 45 spontaneous cycles of 45 control women (solid line) and in 20 LUF cycles of 20 infertility patients (broken line). 


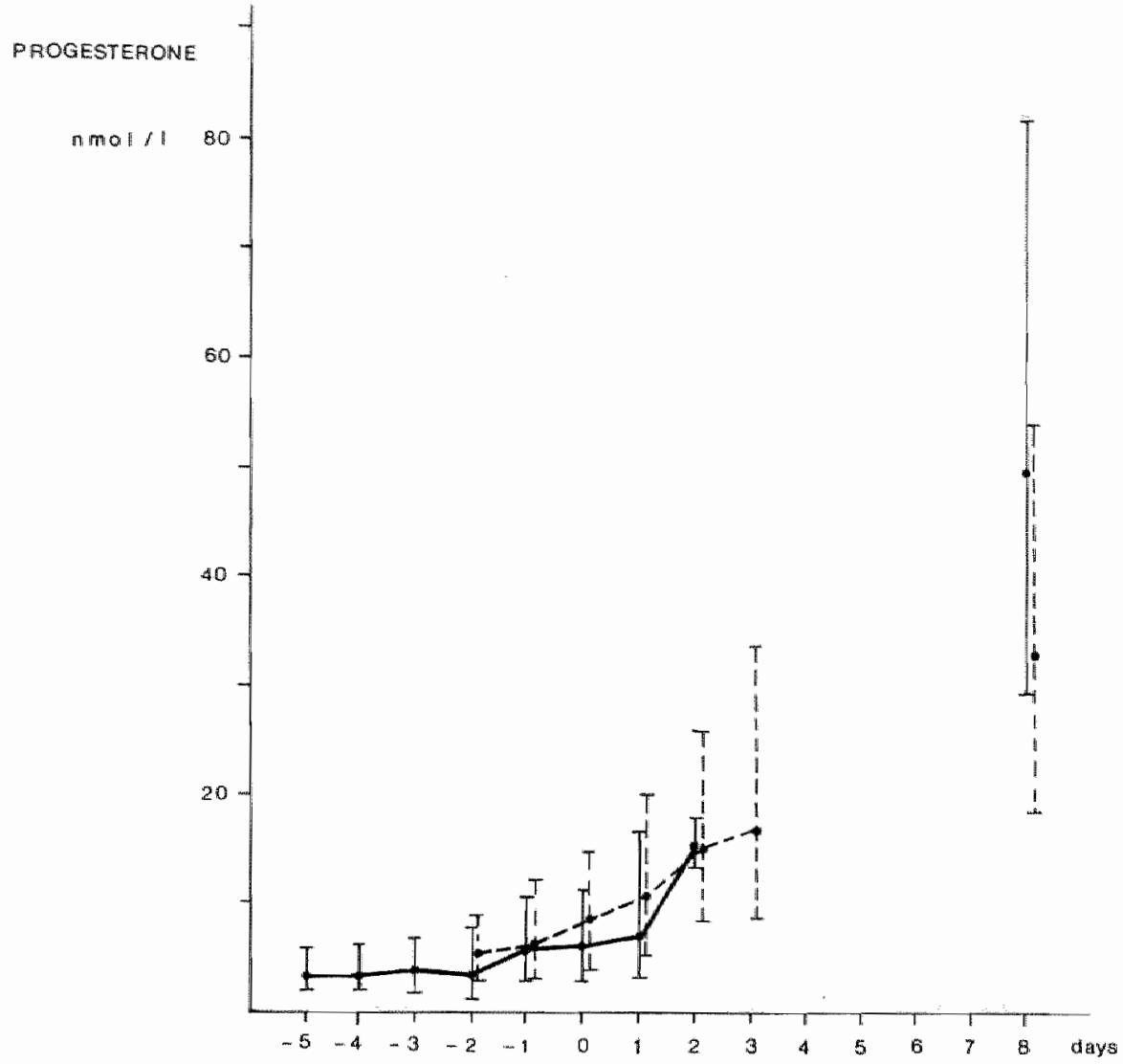

Figure IV.5

Estimated $5 \mathrm{th}, 50 \mathrm{th}$, and $95 \mathrm{th}$ percentiles of serum $P$ levels in 45 spontaneous cycles of 45 control women (solid line) and in 20 LUF cycles of 20 infertility patients (broken line).

later than in the ovulatory cycles. The duration of the luteal phase was the same in both groups.

The LUF occurred in $10 \%$ of the patients studied ( 27 of 270 ), and in $6.7 \%$ of the cycles ( 40 of 600 ). Recurrence of LUF was noted only in patients with ovulation induction and in those with previous pelvic inflammatory disease (PID).

\section{Discussion}

Most of the studies dealing with the LUF syndrome use laparoscopy to investigate this ovulation disorder. The absence of an ovulation stigma in the early luteal phase 
of the menstrual cycle and the presence of low PF sex steroid concentrations are the criteria applied to substantiate the diagnosis (Marik and Hulka, 1978; Koninckx et al., 1978; Koninckx et al., 1980a).

Perception of a stigma, however, may be hampered by pelvic adhesions and by the fact that sometimes a rapid reepithelialization of the stigma occurs. Vanrell and coworkers (1982) questioned the value of the stigma in diagnosing the LUF syndrome. They found no stigma in $47 \%$ of normally ovulating fertile women. Portuondo et al. (1983) could demonstrate no stigma in four of six cycles, which eventually turned out to be conception cycles.

While low PF sex steroid levels are a common denominator in patients with the LUF syndrome, an overlap exists between both $P$ and $E_{2}$ levels in the $P F$ in two groups of patients, with and without a stigma. This overlap even increases if cystic corpora lutea are incorporated into the study (Koninckx et al., 1980a).

Although some investigators applied ultrasonography (Liukkonen et al., 1984; Coulam et al., 1982; Coulam et al., 1983; Coutts et al., 1982; Kerin et al., 1983) in diagnosing the LUF syndrome, data are conflicting and the number of cycles studied is usually limited. No prospective, standardized study has been published of the follicular growth pattern in LUF cycles as compared to the growth of the follicle in normal ovulatory cycles.

The present investigation reveals the LUF cycles to have a characteristic follicle growth pattern. It was found in each individual LUF cycle, notwithstanding the fact that the underlying cause for the failure to rupture varied widely between patients (Table IV.1). The growth of the follicle in the follicular phase of the LUF cycles was identical to the growth of the follicle in the follicular phase of the ovulatory cycles. The mean diameter of the dominant follicle in the LUF cycles increased from 14.8 $\mathrm{mm}$ on day -5 to $23.9 \mathrm{~mm}$ on the day of the $\mathrm{LH}$ peak (day 0). In the control group of ovulatory cycles, an increase was found from $13.2 \mathrm{~mm}$ on day -5 to $21.5 \mathrm{~mm}$ on day 0. Following the LH peak in the LUF cycles, however, a rapid increase of the foilicular diameter was observed to reach a mean value of $33.4 \mathrm{~mm}$ on day +3 , followed by a mean plateau value of $35.5 \mathrm{~mm}$ (range: 29 to $70 \mathrm{~mm}$ ). Most of the follicles retained their well-defined outline; occasionally some blurring of the follicular wall echoes was found. The follicular contents, however, always remained sonolucent. The fact that daily abservations of the ovulatory process were performed precluded the accidental incorporation of a cystic corpus luteum into our study. The sudden increase in diameter following the LH peak in patients with the LUF syndrome has not been described before. This increase in size may be explained by the increased vascularization which accompanies luteinization and which gives rise, by increased exudation, to a higher protein concentration in the follicle fluid. Manarang-Pangan and Menge (1971) found that the protein concentration in cyst fluid was higher than in normal preovulatory follicles.

It must be emphasized that around the time ovulation is expected, daily ultrasonographic observations of the follicle must be performed in order to differentiate the LUF syndrome from cystic corpora lutea. Observations in the normal ovulatory 
cycles of the control women always fulfilled the ultrasound ovulation criteria mentioned earlier. Cystic corpora lutea did occur, but they were formed only several days after the ovulatory decrease in mean follicular diameter of the preexisting follicle. The rapid increase in mean follicular diameter, which was a consistent phenomenon in the LUF cycles, was never observed in healthy volunteers of proven fertility. An occasional ultrasound investigation performed several days after the LH peak cannot distinguish a cystic corpus luteum from an LUF. In our material we did not encounter LUFs that lacked the typical rapid increase in mean follicular diameter following the LH peak. However, if such LLF follicles should exist, they could not be distinguished from normal ovulating follicles, by our criteria for ultrasonographic ovulation, when they show a decrease in mean follicular diameter following the LH peak.

Retention of the oocyte within ruptured follicles has been reported recently (Stanger and Yovich, 1984). This phenomenon cannot be diagnosed by ultrasound either. The higher mean serum level of $E_{2}$ in the group of patients with an LUF cycle can be explained by the fact that some of them were treated with clomiphene citrate (CC) (Wetzels, 1983). The growth curve of the follicle during the follicular phase was not altered by $\mathrm{CC}$ administration in the present study. This is in agreement with the findings of Wetzels and Hoogland (1982), who reported that if monofollicular development occurs, no difference exists between the growth curves of follicles in spontaneous and $\mathrm{CC}$-induced cycles. A significant difference was found between LH peak levels in ovulatory and LUF cycles. This can be an indication of the fact that a defective $\mathrm{LH}$ release may play a role in the pathogenesis of the LUF syndrome. Koninckx and co-workers (1981) did not find such a difference between LH peak levels.

The higher $\mathrm{P}$ levels which we found around the expected day of ovulation in the LUF cycles have also been found in CC-induced cycles (Wetzels, 1983).

A remarkable finding was the low midluteal $P$ level in the LUF cycles, whereas the duration of the luteal phase was not altered. A deficiency of the luteal phase in cycles with a cystic follicular structure has also been described by Coutts and associates (1982). Although Koninckx and co-workers (1978) reported a delayed onset of luteinization in their original article, they did not confirm this in a later study (Koninckx et al., 1981).

Our findings with respect to the eventual dimensions reached by the LUF follicles conflict with the observations reported in the literature. Jones et al. (1970) described in 1970 the occurrence of a small LUF in a patient following ovulation induction. Koninckx and co-workers (1978) noted the abnormal large size of the persisting cystic follicle in only $10 \%$ of the laparoscopically diagnosed LUF cycles. This puts doubt on the suitability of laparoscopic observation for the correct diagnosis of enlargement of the follicle.

In three patients with ultrasonographic evidence of failed follicle rupture, we collected PF by culdocentesis or laparoscopy. The steroid levels in these PF samples met the criteria put forward by Koninckx and associates (1980a) to diagnose the 
LUF syndrome. The growth curves of the LUF follicles in these patients were identical to those obtained in the other LUF patients; so, at least ultrasonographically, we were dealing with the same ovulation defect.

Very little is known about the pathophysiology of the LUF syndrome. Koninckx and co-workers (1984) associated the LUF syndrome with psychogenic infertility and suggested stress hyperprolactinemia as one of the possible causes. In the present study, in those patients monitored during more than one cycle, it was striking that if only one LUF cycle occurred, this always happened in the first of the monitored cycles. This cycle was usually 2 or 3 days longer than the same patient's normal cycles. The LH peak occurred, on the average, 2.3 days later in the group of LUF cycles, compared to the control group. Perhaps this can also be explained by the psychogenic stress effects of the required adaptation to this new diagnostic procedure. Among patients in Table IV.1, three separate subgroups can be discerned: (1) a group with spontaneous cycles and an unexplained infertility (4 LUF cycles of 17 cycles monitored); (2) a group of patients undergoing ovulation induction (16 LUF cycles of 28 cycles monitored); and (3) a group of patients with a history of PID (17 LUF cycles of 21 cycles monitored). LUF did occur repetitively only in patients from the last two subgroups. The occurrence of these three distinct groups of patients with the LUF syndrome indicates that multiple causes may exist for the lack of follicle rupture.

We demonstrated a significantly lower mean LH peak level in LUF cycles than in normal ovulatory cycles, whereas the follicular development before the LH peak appeared to be identical. This observation suggests that a central disturbance of the LH release is one possible cause of the LUF syndrome. This hypothesis is supported by the clinical data of some patients. Patient 16 (Table 1) was being treated with LH-releasing hormone (LHRH) by an intravenous infusion pump, because of hypogonadotropic amenorrhea. Due to a leakage of the infusion system, around the time the LH peak was expected, no medication was administered for a period of 24 hours in the only cycle in which she exhibited an LUF. Patient 3 , in her only LUF cycle of six monitored cycles, was treated with ethinylestradiol (EE), to ameliorate the cervical factor. EE might interfere with the $\mathrm{LH}$ release by feedback mechanisms. Jones et al. (1970) described histologically abnormal corpora lutea in patients treated with $\mathrm{CC}$, and attributed this to defective patterns of gonadotropin release. In 17 of our 40 LUF cycles $(42.5 \%)$ ovulation induction was applied, predominantly by means of CC. For a local etiology argues the fact that so many LUF patients had a PID in their history. A comparable obserwation has been made by Lesorgen and co-workers (1984). Periovarian adhesions seem to be responsible for the failure of the follicle to rupture. For this specific type of ovulation disturbance we propose the term "mechanically unruptured follicle syndrome". After microsurgical removal of these adhesions from the ovarian surface, in some patients the LUF syndrome persisted. A postinfectious oophoropathy or a subclinical oophoritis might be the cause of the ovulation disturbance in these patients. This hypothesis is corroborated by the observation of Toth (1983), who found luteal phase defects in 
patients with a previous PID and who saw normalization of the luteal phase following intravenous antibiotic therapy. In the literature several investigators demonstra ted a relationship between endometriosis and the LUF syndrome (Koninckx et al., 1980b). Only one of our patients was found to have endometriosis.

Enzymatic disorders may also constitute a local cause of the LUF syndrome. This was demonstrated by patient 11 , in whom the follicular fluid clotted spontaneously, immediately after aspiration during laparoscopy. Because plasminogen plays a crucial role in both fibrinolysis and in autodigestion of the follicle wall following the LH surge (Beers, 1975), a failure of plasminogen synthesis, perhaps due to insufficient plasminogen activator activity, may lead to both clotting of the follicular fluid and to failure of the follicle to rupture. Both a central inadequacy of $\mathrm{LH}$ secretion and a local granulosa cell defect may give rise to an enzymatic failure of the follicle to rupture.

Reviewing the gamut of clinical data of the patients with an LUF, we conclude that several factors, both central and local, can be held responsible for the failure of the follicle to rupture. Further research into the characteristics of the various subgroups is ongoing. A common ultrasonographic finding in every patient with an LUF cycle was the characteristic two-step follicular growth pattern. Repeated LUF cycles were found only in patients with a history of PID and in patients with ovulation induction. This excludes the LUF syndrome as an important cause of unexplained infertility. In our opinion, ultrasound will be an invaluable tool for future research into ovulation disorders and menstrual disturbances.

\section{References}

Beers, W.H.: Follicular plasminogen and plasminogen activator and the effect of plasmin on ovarian folJicle wall.

Cell $6.379,1975$

Coulanm, C.B., Hill, L.M., Breckle, R.: Ultrasonic evidence for luteinization of unruptured preovulatory follicles.

Fertil Steril $37: 524,1982$

Coulam, C.B.. Hill, L.M., Breckle, R.: Ultrasonic assessment of subsequent unexplained infertility after owulation induction.

Br J Obstet Gynaec $90: 460,1983$

Coutts, J.R.T., Adam, A.H., Fleming, R.: The deficient luteal phase may represent an anowulatory cy$\mathrm{cle}_{\text {. }}$

Clin Endocrin (Oxf) 17:389, 1982

Dmowski, W.P., Rao, R., Scommegma, A.: The luteinized unruptured follicle syndrome and endornetriosis.

Fertil Steril $33: 30,1980$ 


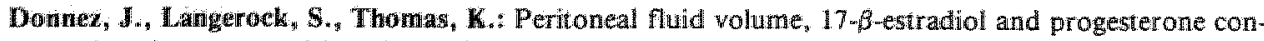
centrations in women with endometriosis and/or luteinized unruptured follicle syndrome.

Gynecol Obstet Invest 16:210, 1983

Jewelewicz, $\mathbf{R}$.: Managemetit of infertility resulting from anovulation.

Ain J Obstet Gynecol 122:909, 1975

Jones, G.S., Marlezroli, R.D., Strott, G.A., Ross, G.T., Kaplan, G.: Pathophysiology of reproductive failure after clomiphene-induced owulation.

Am J Obstet Gynecol 108:847, 1970

Kerin, J.F., Kirby, C., Morris, D., MeEvoy, M., Ward, B., Cox, L.W.: Incidence of the luteinized un. ruptured follicle phenomenon in cycling women.

Fertil Steril $40: 620,1983$

Kletzky, A.0., Nakamura, R.M.., Thorneycroft, I.H., Mishell, D.R.: Log normal distribution of gonadotropins and ovarian steroid values in the normal menstrual cycle.

Am J Obstet Gynecol 121:688, 1975

Koninckx, P.R., Heyns, W.J., Corvelyn, P.A., Brosens, 1.A.: Delayed onset of luteinization as a cause of infertility.

Fertil Steril 29:266, 1978

Koninckx, P.R., De Moor, P., Brosens, I.A.: Diagnosis of luteinized unruptured follicle syndrome by steroid hormone assays on peritoneal fluid.

Br J Obstel Oynaecol 87:929, 1980a

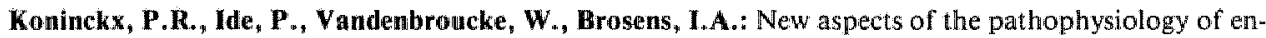
dometriosis and associated infertility.

I Reprod Med 24:257, 1980b

Koninckx, P.R.. Brosens, I.A., Verhoeven, G., De Moor, P.: Increased postovulatory plasma folliclestimulating hormone levels in luteinized unruptured follicle syndrome: a role for inhibin?

$\mathrm{Br}$ J Obstet Gynaecol 88:525, 1981

Koninckx, P., Nijs, P., Verstraeten, D., Mullens, A-M., Nicasy, H., Van Tendeloo, G., Brosens, I.: Suggestive evidence for a psychogenic infertility: increased stress response and stress sensitivity in women with the LUF syndrome.

Fertil Steril $41: 95 \mathrm{~S}, 1984$

Lesorgen, P.R., Wu, C.H., Green, P.J., Gocial, B., Lerner, L.J.: Peritoneal fluid and serum steroids in infertility patients.

Fertil Steril $42: 237,1984$

Litukkonen, S., Koskimies, A.I., Tenhunen, A., Ylöstalo, P.: Diagnosis of luteinized unruptured follicle (LUF) syndrome by ultrasound.

Fertil Steril 41:26, 1984

Manarang-Pangan, S., Menge, A.C.: Immunologic studies on human follicular fluid.

Fertil Steril 22:367, 1971

Marik, J., Hulka, J.: Luteinized unruptured follicle syndrome: a subtle cause of infertility.

Fertil Steril 29:270, 1978

Partuondo, J.A., Pena, J., Otaolla, C., Echanojauregui, A.D.: Absence of ovulation stigma in the conception cycle.

Int J Fertil 28:52, 1983 
Stanger, J.D., Yovich, J.L.: Failure of human oocyte release at ovulation.

Fertil Steril 41:827, 1984

Toth, A.: Intrawenous antibiotic therapy for luteal phase defect and premenstrual syndrome. Presented at the Elewenth World Congress on Fertility and Sterility, Jume 26 to July 1, 1983, Dublin, Ireland. Dublin, published by IFFS, Abstract 536

Vanrell, J.A., Balasch, J., Fuster, J.S., Fuster, R.: Ovulation stigma in fertile women.

Fertil Steril $37: 712,1982$

Wetzels, L.C.G., Hoogland, H.J.: Relation between ultrasonographic evidence of ovwlation and hormonal parameters: luteinizing hormone surge and initial progesterone rise.

Fertil Steril $37,336,1982$

Wetzels, L.C.G.: Ultrasonographical Aspects of Follicle Growth.

Thesis, University of Limburg, Maastricht, 1983 , p 27

Zerbe, G.O.: Randomization analysis of completely randomized design extended to growth and response curves.

J Am Statist Assoc 74:215, 1979 



\section{Ovulatory disorders and inflammatory adnexal damage: a neglected cause of the failure of fertility microsurgery.}

Hamilton, C.J.C.M., Evers, J.L.H., Hoogland, H.J. (British Journal of Obstetrics and Gynaecology 93:282, 1986)

(with permission)

\section{Summary}

Failure of reconstructive tubal surgery is usually attributed to pre-existing endosalpingeal damage, recurrent adhesion formation or progressive inflammatory disease. We studied ovarian follicle development and ovulation by ultrasound in 25 infertile patients with laparoscopically proven sequelae of pelvic inflammatory disease. Failure of the follicle to rupture was seen in 13, although luteinization occurred. The mean midluteal progesterone concentration in cycles with an unruptured follicle was significantly lower than the concentrations both in ovulatory cycles in the same patients and in a comparison group of 45 normally ovulating women $(\mathrm{p}<0.01)$. Microsurgical adhesiolysis did not seem to influence the occurrence of the ovulation disorder. 


\section{Introduction}

Tubal damage and disturbances in tubo-ovarian relations are the main causes of the severely decreased fertility that often follows pelvic inflammatory disease (PID). Microsurgical techniques can more or less successfully reconstruct the damaged Fallopian tubes after careful adhesiolysis, but postoperative patency is associated with low pregnancy rates.

Irreversible destruction of endosalpingeal epithelium, recurrent adhesion formation and progressive inflammatory disease are thought to account for the failures of reconstructive tubal surgery, but Gomel (1983) noted that anovulation and luteal phase defects were common in such patients. We decided to monitor follicular development and ovulation with ultrasound in women with a history of PID. The study only included women with an otherwise unexplained infertility of at least 1 year duration.

\section{Material and methods}

The 25 women included in the study were infertile and all had a history of PID, 17 of them had a primary infertility and the other eight had secondary infertility. The patients" ages ranged from 20 to 32 years $(27.8 \pm 3.2$, mean $\pm \mathrm{SD})$. We assigned the diagnosis "past-PID" to these patients, because laparoscopically each of them had uni- or bilateral hydrosalpinges with or without adhesions. Endometriosis was not found in any patient. Eleven patients had a history of clinically obvious adnexitis; two others had suffered from a perforated appendix; and one other had had an abscess in the cul-de-sac. The remaining 11 patients had no history of pelvic infection but, at laparoscopy, they had clear signs of damage due to infection.

Five patients did not have surgical treatment because only minor adhesions existed and the Fallopian tubes were patent. Five patients were investigated before surgery. The remaining 15 were examined after reconstructive microsurgery (Table V.1). The time interval between operation and ultrasound investigation varied between 3 months and several years $(21 \pm 15$ months, mean $\pm \mathrm{SD})$. All patients had regular menstrual cycles with biphasic basal body temperature charts and midluteal serum progesterone concentrations, indicating adequate luteinization. A group of 45 normally ovulating women, without pelvic adhesions, served as a comparison group. The women's ages ranged from 19 to 39 years $(29.1 \pm 4.0$, mean $\pm \mathrm{SD})$. All women were investigated according to a rigid, well-defined prospective protocol. Ultrasound investigations started on day 8 of the cycle and were repeated every other day until the dominant follicle had reached a mean diameter of $15 \mathrm{~mm}$. From then on daily ultrasound scans were performed. If ovulation occurred a final ultrasound scan was performed after 7 days to assess the corpus luteum in the midluteal phase. 
The occurrence of foilure of the follicle to rupture (FFR) in the various groups of women

\begin{tabular}{|c|c|c|c|}
\hline Patient group & $N$ & FFR & $\%$ \\
\hline \multicolumn{4}{|l|}{ Comparison group } \\
\hline - women & 45 & 0 & 0 \\
\hline - cycles & 45 & 0 & 0 \\
\hline \multicolumn{4}{|l|}{ No surgery } \\
\hline - patients & 5 & 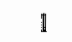 & 20 \\
\hline - cycles & $\mathbb{1 1}$ & $\mathbb{1}$ & 9 \\
\hline \multicolumn{4}{|l|}{ Before surgery } \\
\hline - patients & 5 & 3 & 60 \\
\hline - cycles & 11 & 4 & 36 \\
\hline \multicolumn{4}{|l|}{ Following surgery } \\
\hline - patients & 15 & 9 & 60 \\
\hline - cycles & 31 & 17 & 55 \\
\hline
\end{tabular}

$\mathrm{N}=$ number of patients

FFR = failure of the follicle to rupture

If the follicle did not rupture, daily scanning was continued for three more days after the largest follicle had reached a mean diameter of $30 \mathrm{~mm}$, or until the dominant follicle did not grow any further for three successive days. Further scans were performed at 3-day intervals during the remaining part of the luteal phase.

Ultrasound investigations were performed using a static compound B-mode scanner (Emisonic NE 4201).

All ultrasound measurements were carried out by the same investigator (C.H.). Daily blood samples were obtained to detect the LH surge and to determine the midluteal serum progesterone concentration.

\section{Results}

In $13(52 \%)$ of the 25 patients with past PID the dominant follicle failed to rupture during one or more cycles. After the LH surge, instead of ovulation, accelerated growth of the dominant follicle was observed and a mean follicular diameter of 35 $\mathrm{mm}$ was reached (range: $28-45 \mathrm{~mm}$ ). Subsequently, the dimensions of the unruptured follicle decreased gradually towards the end of the cycle and sometimes into the early phase of the subsequent cycle. This biphasic follicle growth curve is identical to the folliclle growth curve described in patients with the luteinized unruptured follicle syndrome (Hamilton et al. 1985). Serum progesterone levels increased following the $\mathrm{LH}$ surge in every patient and the basal body temperature (BBT) was bi- 
phasic in spite of the failure of the follicle to rupture. The mid-luteal serum progesterone concentration was higher during ovulatory cycles $(49 \pm 20 \mathrm{nmol} / \mathrm{l}$, mean \pm SD) than in cycles with an unruptured follicle in the same patients (33 \pm 7 $\mathrm{nmol} / 1$, mean $\pm \mathrm{SD})(\mathrm{p}<0.01$; Student's $\mathrm{t}$-test). The midluteal progesterone level in the comparison group was $51.1 \pm 15.7 \mathrm{nmol} / 1$ (mean $\pm \mathrm{SD}$ ).

All blood samples for mid-luteal progesterone determinations were taken between the 5 th and the 9th day (mean 7.5 days) after the day of the LH peak.

The mean length of the ovulatory cycles in the patient group was 29.3 days and the calculated mean day of the LH peak was day 15.5 of the cycle. In the cycles in which the follicle did not rupture the cycle length was 28.8 days and the $\mathrm{LH}$ peak occurred on day 15.0. In the comparison group the mean duration of the cycle was 29.5 days and the average dlay of the LH peak was day 15.2. There were no statistically significant differences between these values in the three groups. A failure of the follicle to rupture, with signs of luteinization, was observed in $20 \%$ of the patients who did not have surgical treatment (Table V.1). Patients, who were scanned before reconstructive microsurgery, were found to have a failure of follicular rupture similar to that in patients examined after surgery $(60 \%)$.

In the comparison group no failure of follicular rupture was observed.

Women whose follicles failed to rupture in one cycle usually had a similar failure in the next cycles. In 13 women with such failure in one or more cycles, 22 of 25 cycles showed an unruptured follicle $(88 \%)$.

\section{Discussion}

Usually causes other than ovarian dysfunction are held responsible for the failure of reconstructive pelvic microsurgery to cure infertility, but we wondered whether ovulation disorders could play an important role in infertility after pelvic inflammation.

We demonstrated a failure of the follicle to rupture in a considerable number of patients. The patients in the present study are not a random sample of the entire population of patients with a history of PID, as they were selected, because treatment for infertility had been unsuccessful for at least 1 year. Not every patient contributed an equal number of ultrasound-monitored cycles to this study. However, in the patients investigated, luteinized unruptured follicles were a serious cause of the "failure" of fertility microsurgery. Recurrent adhesion formation may be a reason for the failure of the follicle to rupture. In 14 of our patients, a second-look laparoscopy was performed 1 year after microsurgery. In six patients we found filmy adhesions covering the ovarian surface and small grape-like structures hanging from the ovaries. The steroid hormone concentration of the cyst fluid was above serum and peritoneal fluid steroid hormone levels. The film of adhesions covering 
the surface of the ovary may constitute a mechanical barrier to ovulation in some cases, and causes entrapment of the ovum and the follicular fluid in others.

However, second-look laparoscopy demonstrated "normal" ovaries in 8 of 14 operated patients. In them, another defect must be responsible for the ovulation disorder. Toth (1984) found distinct inflammatory changes in ovarian biopsy specimens from women who had a diagnosis of luteal phase defect, confirmed by hormonal estimations and endometrial biopsy. He postulated that a subclinical oophoritis may alter the endocrine function of the ovaries.

Follicle rupture is based partly upon delicate prostaglandin mediated processes and upon plasminogen activator induced digestion of the follicle wall. Perhaps the interspersed macrophages of ovarian inflammatory disease interfere with these processes and prevent rupture of the follicle wall. This may explain the observation of Hulka (1982), that when periovarian adhesions cover more than half of the ovarian surface, the prognosis after microsurgery is extremely poor.

The large luteinizing unruptured follicles observed in the present investigation, the subclinical oophoritis observed by Toth (1984) and the luteal phase defects described by Gomel (1983) most probably are different aspects of one and the same entity: postinfective oophoropathy leading to impairment of follicle development, disturbance of ovulation and insufficiency of the luteal phase.

We suggest that follicle growth and ovulation should be monitored with ultrasound for at least one menstrual cycle after infertility microsurgery. Those patients showing recurrent failure of the follicle to rupture should benefit from early referral for in-vitro fertilization.

\section{References}

Gomel, V.: Microsurgery in Female Infertility.

Toronto: Little, Brown and Company, pp. 245-251, 1983

Hamilton, C.J.C.M., Wetzels, L.C.G., Evers, J.L.H., Hooglhand, H.J., Muytjens, A., de Maan J.A Follicle growth curves and hormonal patterns in patients with the luteinized unruptured follicle syndrome. Fertil Steril $43: 541,1985$

Hulka, J.F.: Adnexal adhesions: A prognostic staging and classification system based on a fiwe-year survey of fertility surgery results at Chapel. Hill, North Carolina.

Am II Obstet Gynecol 144:141, 1982

Toth, A.: Asymptomatic oophoritis discovered during infertility workup.

In: Scientific Program and Abstracts, Thirty-first Annual Meting of the Society for Gynecologic Investigation, San Francisco, USA, March 21.24, pp. 186, 1984 



\section{Chapter VI}

\section{Ovulatory disturbances in patients with luteal insufficiency}

Hamilton, C.J.C.M., Evers, J.L.H., de Haan, J.

(Clinical Endocrinology, accepted for publication)

\section{Summary}

In order to study the occurrence of ovulatory disturbances in patients with luteal insufficiency we evaluated 210 cycles of 170 women from infertile couples by ultrasonographic follicle measurements and hormonal determinations. Only cycles with evidence of luteinization were included into the study. Midluteal progesterone $(\mathbb{P})$ levels were determined in relation to the ultrasonographic ovulation time or, where the follicle failed to rupture, in relation to the LH peak. In spontaneous cycles with a midluteal $P$ level below $32 \mathrm{nmol} / 1(10 \mathrm{ng} / \mathrm{ml})$ a luteinized unruptured follicle (LUF) was found in $71.1 \%$ of cycles, whereas in spontaneous cycles with a midluteal $\mathrm{P}$ level above $32 \mathrm{nmol} / \mathrm{l}$ only $7.9 \%$ cycles exhibited a failure of the follicle to rupture. The same phenomenon was encountered in cycles in which agents had been given to induce ovulation.

The incidence of LUF cycles in an average infertility population could be calculated to be as high as $50 \%$ if the midluteal $\mathrm{P}$ level is below $32 \mathrm{nmol} / 1$ and as $10 \mathrm{w}$ as $4 \%$ if the midluteal $P$ level is above $32 \mathrm{nmol} / 1$. The median midluteal $P$ level in spontaneous LUF cycles was $32.5 \mathrm{nmol} / \mathrm{l}$, compared to $55.2 \mathrm{nmol} / \mathrm{l}$ in spontaneous ovulatory cycles $(\mathrm{p}<0.001)$. We conclude that in patients with luteal insufficiency a high incidence is found of a failure of the follicle to rupture. The entrapment of the oocyte in the unruptured follicle constitutes an important cause of infertility in these patients. 


\section{Introduction}

Luteal insufficiency (L1) is ustally considered to be a disorder of the ovulatory cycle. This cycle disturbance is characterized by a subnormal progesterone (P) production by the corpus luteum, resulting in a delayed secretory transformation of the endometrium, and may be associated with a short duration of the luteal phase (Jones, 1976; Andrews, 1979).

The clinical significance of $\mathrm{LI}$ is the inability of patients with this abnormality to establish or to maintain a pregnancy (Jones and Delfs, 1951).

Histological dating of an endometrial biopsy, basal body temperature (BBT) charts and serum $P$ assays have been applied as diagnostic tools (Jones, 1976; Andrews, 1979). Most investigators time the biopsies and hormonal assays relative to the rise of the temperature on the BBT chart. The determination of the exact time of ovulation on BBT recording, however, is known to be imprecise (Wetzels et al., 1982; Baumann, 1981). We therefore evaluate luteal function in a more standardized way, by determining serum $\mathbf{P}$ levels relative to the ultrasonographic ovulation time. Ovarian ultrasound investigation is a reliable and noninvasive method of ovulation detection (Wetzels and Hoogland, 1982).

Coutts and coworkers (1982) were the first to indicate that LI may also represent an anovulatory cycle. They found significantly lower midluteal $P$ levels in patients with retained luteal phase cysts, as diagnosed by ultrasound, compared to patients with ovulatory cycles. Koninckx and coworkers (1978) described a delayed rise of $P$ level associated with a delayed rise of the BBT in patients who failed to have an ovulation stigma in the early luteal phase. The datings of the endometrial biopsies were in phase with the onset of the BBT rise, but not with the LH peak.

In a previous study we described the characteristic follicular growth curves in patients with the luteinized unruptured follicle (LUF) syndrome (Hamilton et al., 1985). The ovulatory disturbance occurred in $10 \%$ of infertile patients ( 27 of 270 patients) and in $6.6 \%$ of cycles ( 40 of 600 cycles). Follicular growth curves and hormonal parameters of 20 LUF cycles were compared with 45 ovulatory control cycles. We found a significantly lower midluteal $P$ level in LUF cycles. From this study a relation appeared to exist between LI and the LUF syndrome. To be able to assess the importance of ovulatory disturbances in patients with $\mathrm{LI}$, we decided to study the incidence of $\mathrm{LI}$ in ovulatory cycles of infertile patients. The present study was designed to investigate in more detail the relation between LI and the LUF syndrome.

\section{Material and methods}

In our earlier study of follicular growth patterns in LUF patients (Hamilton et al., 
1985) 600 menstrual cycles of 270 patients were studied. In 254 cycles of 100 patients, including 20 LUF patients, sufficient hormonal data were available to allow us to investigate the adequacy of the luteal phase. Collection of blood samples in the luteal phase depended on the willingness of the patient to return to the clinic for luteal $\mathrm{P}$ determinations. No selection of patients was made, except for patients with an LUF cycle, in whom $P$ levels were determined serially in every cycle.

The study progressed meanwhile and additional patients were referred to our clinic. This resulted in the collection of hormonal data in another 184 cycles of 70 patients, including another 10 LUF patients, making a total of 438 menstrual cycles in 170 patients. Only the first examination cycle of each patient was selected, with the exception of a group of 40 patients, of whom, apart from one LUF cycle or one induced ovulatory cycle, also one spontaneous ovulatory cycle was incorporated into the study. Thus, the study population consisted of a total number of $210 \mathrm{cycles}$ from 170 infertile patients.

The mean age of the patients was 28.6 years. The study group reflects the population of patients attending the fertility clinic. One hundred and twenty-one women had a history of primary infertility, and 49 of secondary infertility.

In 90 patients ultrasonographic follicle measurements were performed as the first diagnostic step in the infertility screening. Twenty-four were monitored because the traditional fertility workup had not revealed any explanation for their infertility. Twenty-two patients were monitored because ovulation was induced with gonadotropins or luteinizing hormone releasing hormone (LHRH). In the remaining 34 patients ovulation was monitored by ultrasound to time artificial insemination (17 patients), to study periovulatory mucus production (10 patients) or to give the couple advice about the optimal time to have intercourse ( 7 patients).

The total number consisted of 141 spontaneous cycles and 69 stimulated cycles (45 clomiphene-citrate $(\mathrm{CC})$ induced cycles, 14 cycles stimulated with human Menopausal Gonadotropin/human Chorionic Gonadotropin (hMG/hCG), and 10 cycles induced by pulsatile administration of LHRH). Except in cycles treated with hMG, no hCG was given. CC was administered because of anovulation or oligomenorrhoea, LHRH because of hypothalamic amenorrhoea, and gonadotropins because of CC-resistent anovulation.

Follicular growth and ovulation were monitored by applying daily ovarian ultrasound during the late follicular phase. Cycles with a midluteal P level below 9.6 $\mathrm{nmol} / \mathrm{l}(3 \mathrm{ng} / \mathrm{ml})$ were excluded from the study, since they are usually considered to indicate a lack of luteinization (Israel et al., 1972). Daily blood samples were collected in all 210 cycles immediately before each ultrasound investigation. Serum was separated and stored at $-20^{\circ} \mathrm{C}$, until assayed for $17-\beta$-estradiol $\left(E_{2}\right), L H$ and $P$. All hormone determinations were performed with validated commercially available radioimmunoassay techniques. $E_{2}$ was determined by a double-antibody solid phase kit (Institut für Reactorforschung, Würenlingen, Switzerland), as were LH (National Institute for Radioelements, Fleurus, Belgium) and P (Farmos Diagnostica, Turku, Finland). The intraassay and interassay coefficients of variation for 
$\mathrm{E}_{2}$ were $8.0 \%$ and $9.8 \%$ at the level of $1.10 \mathrm{nmol} / 1$. Those for $\mathrm{LH}$ were $5.0 \%$ and $8.7 \%$ at the level of $49.1 \mathrm{IU} / \mathrm{l}$, and those for $\mathrm{P}$ were $3.4 \%$ and $4.9 \%$ at the level of $11.1 \mathrm{nmol} / 1$.

When the follicle did not rupture, scans were continued until at least 4 days after the day of the LH peak, to confirm the diagnosis of the LUF syndrome (Hamilton et al., 1985).

To assess luteal function in a standardized way, a blood sample was collected six days after ultrasonographic evidence of ovulation (i.e. 7 days after the day of the LH peak). In LUF cycles $P$ levels were determined seven days after the LH peak, to allow comparison with $P$ levels in ovulatory cycles. Since neither a rapid LH assay nor evidence of ovulation was present in LUF cycles, daily blood sampling was continued in these cycles to allow selection of the appropriate blood sample for $\mathrm{P}$ determination, once the day of the LH peak was known. Because the LUF syndrome is characterised by a rapid growth phase in the first 48 hours following the LH peak (Hamilton et al., 1985) and because the ultrasonographic appearance of the endometrium changes considerably in the early luteal phase (Sakamoto and Nakano, 1982), an alternative would have been to determine LH levels in stored samples from the previous days as soon as this rapid growth phase and/or thickening of the endometrium was observed.

The $\mathrm{E}_{2}$ peak was defined as the maximum $\mathrm{E}_{2}$ concentration preceeding or coinciding with the rise of $\mathrm{P}$ above $9.6 \mathrm{nmol} / 1$. The $\mathrm{LH}$ peak was defined as the highest LH concentration measured. The duration of the luteal phase was defined as the interval in clays following (but not including) the day of the LH peak up to and including the day preceding the next menstruation (Lenton and Landgren, 1985).

In all subgroups the incidence of ovulatory disorders was studied, making a distinction between cycles with a midluteal $P$ level above and below $32 \mathrm{nmol} / 1$ respectively. The threshold value of $32 \mathrm{nmol} / 1(10 \mathrm{ng} / \mathrm{ml})$ was chosen to allow comparison with data in literature, a midluteal $\mathbb{P}$ level below this being usually considered as discriminatory between normal and subnormal cycles (Radwanski and Swyer, 1974). Correlation coefficients for hormone concentrations and follicle diameters were calculated. To characterise the hormonal data geometrical means and $95 \%$ confidence limits were calculated. The Student's t-test on the logarithms was used to test for differences in hormone concentrations between groups of cycles. This procedure was applied because of the lognormal distribution of gonadotropins and ovarian steroid values in the normal menstrual cycle (Kletzky et al, 1975). Student's t-test was also used to test for differences in mean preovulatory follicle diameters and the Chi-square test for differences in the incidence of ovulatory disturbances between groups of cycles. 


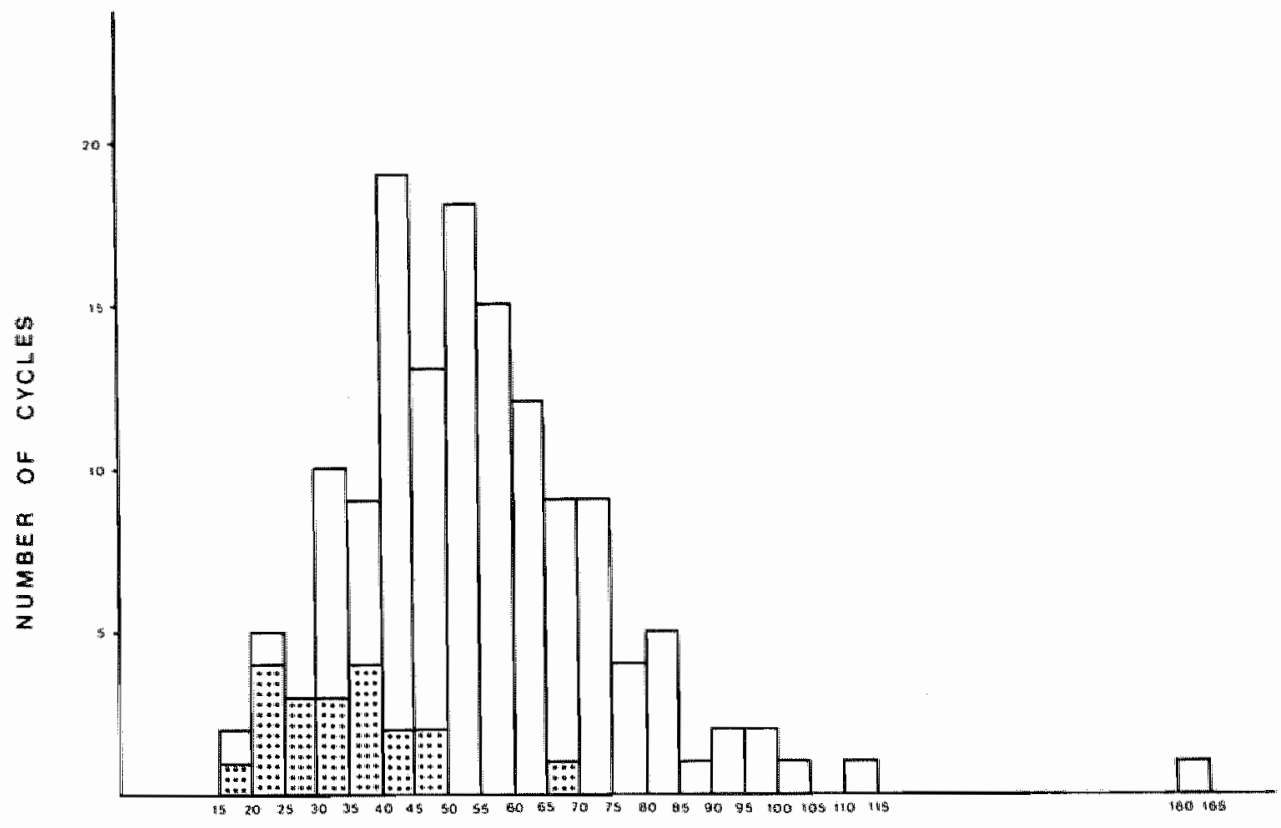

PROGESTERONE ( $\mathrm{mmol} / \mathrm{m})$

Figure VI.I

Frequency distribution of midiuteal serum P concentration in 141 spontaneous cycles. Twenty cycles showed a failure of the follicle to rupture, despite hteinization (dotted area).

\section{Results}

Fourteen out of 141 spontaneous cycles $(9.9 \%)$ had a $\mathrm{P}$ level below $32 \mathrm{nmol} / \mathrm{l}$. In 10 of these 14 cycles $(71 \%)$ we found that the follicle failed to rupture. In the remaining 127 spontaneous cycles, with a midluteal $P$ level above $32 \mathrm{nmol} / 1$, only 10 LUF cycles were found $(7.9 \%)(\mathrm{p}<0.001)$. Five out of $45 \mathrm{CC}$-induced cycles (11.1\%) had a $\mathrm{P}$ level below $32 \mathrm{nmol} / 1$. Three of these cycles were LUF cycles $(60 \%)$. Of the remaining $40 \mathrm{CC}$-induced cycles only three exhibited an LUF $(7.5 \%)$ $(p<0.001)$. In the 14 gonadotropin stimulated cycles neither a midluteal $P$ level below $32 \mathrm{nmol} / 1$ nor an LUF was observed. In the group of $10 \mathrm{LHRH}$ stimulated cycles four $(40 \%)$ had a $\mathrm{P}$ level below $32 \mathrm{nmol} / \mathrm{l}$. These four were all LUF cycles. The six cycles with a $P$ level above $32 \mathrm{nmol} / 1$ were all ovulatory.

The median midluteal $\mathbf{P}$ level in spontaneous LUF cycles was $32.5 \mathrm{nmol} / 1$, whereas that in the spontaneous ovulatory cycles was $55.2 \mathrm{nmol} / 1(\mathrm{p}<0.001)$ (Table VI.1). The median $\mathrm{E}_{2}$ peak level in spontaneous ovulatory and LUF cycles was 0.88 and $0.97 \mathrm{nmol} / 1$, respectively (no significant difference) (Table VI.1). 


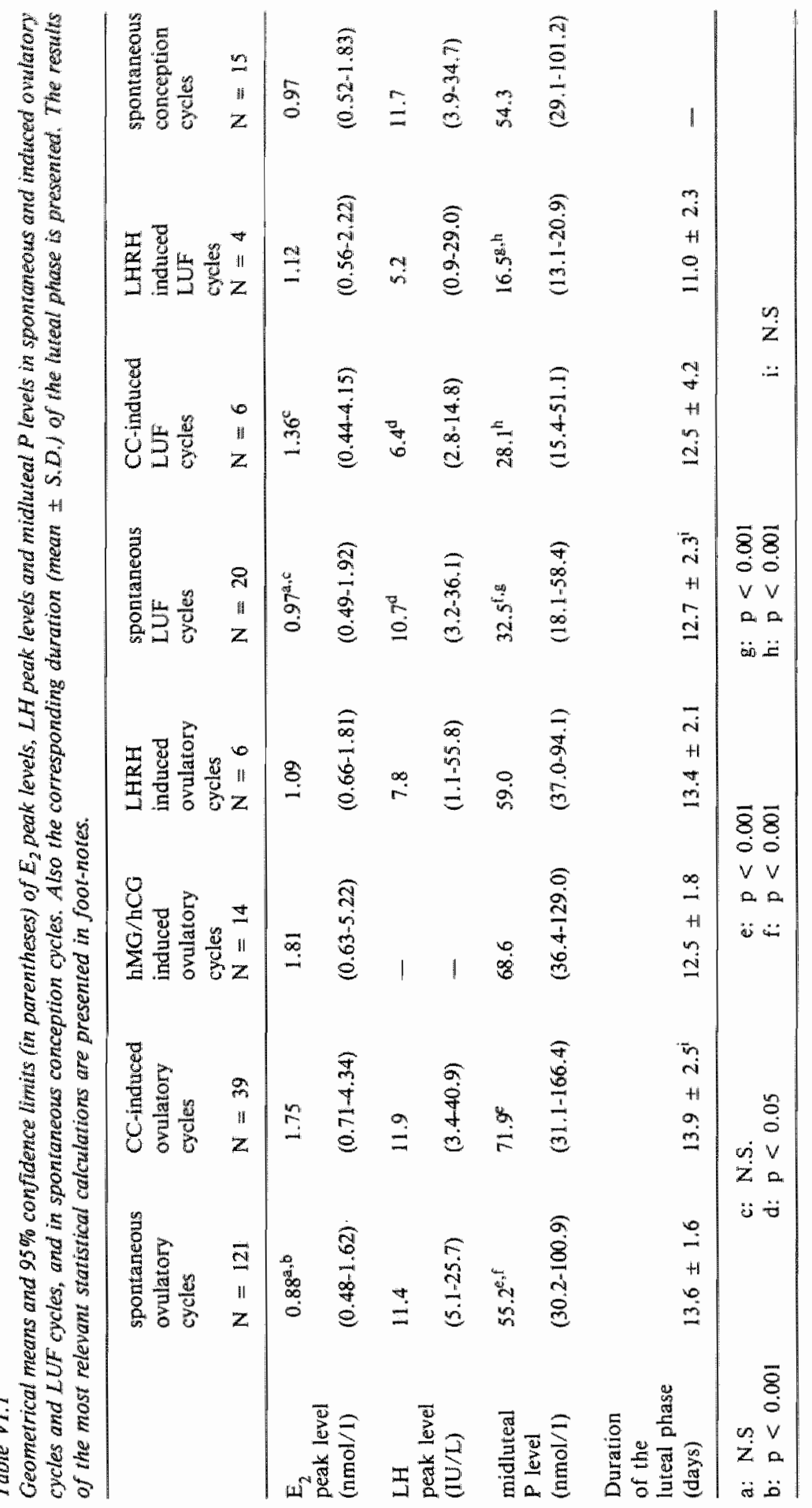




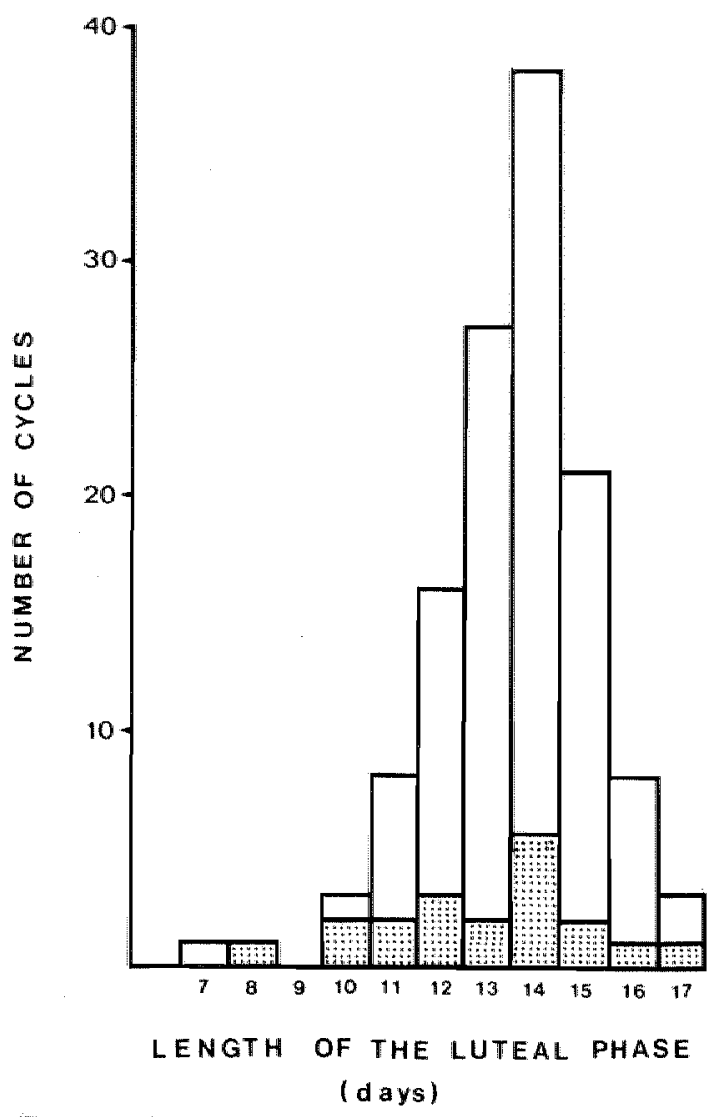

Figure VI.2

Frequency distribution of luteal phase length in 141 spontaneous cycles. Twenty cycles showed a failure of the follicle to rupture (dotted area).

The midluteal P level in LHRH stimulated LUF cycles was significantly lower than in spontaneous or CC-induced LUF cycles (Table VI.1). In ovulatory cycles with a midluteal $\mathbb{P}$ level below $32 \mathrm{nmol} / 1$ the median $E_{2}$ peak level was $0.86 \mathrm{nmol} / 1$, in ovulatory cycles with a midluteal $P$ above $32 \mathrm{mmol} / 1$ the median $\mathbb{E}_{2}$ peak level was $0.88 \mathrm{nmol} / 1$ (no significant difference).

Figure VI.1 shows the frequency distribution of midluteal P levels in the 141 spontaneous cycles. The spontaneous LUF cycles are mainly found in the lower range of P levels.

The mean preovulatory follicle diameter in spontaneous and $\mathrm{CC}$ induced cycles, was $21.3 \pm 3.0 \mathrm{~mm}$ and $25.3 \pm 4.8 \mathrm{~mm}$, respectively $(\mathrm{p}<0.001) . \mathrm{n} \mathrm{hMG} / \mathrm{hCG}$ and LHRH stimulated cycles the mean diameter was $21.0 \pm 3.8 \mathrm{~mm}$ and $22.2 \pm 3.5$ $\mathrm{mm}$, respectively, which was not significantly different from that in spontaneous cycles.

Neither in spontaneous nor in stimulated LUF cycles did multifollicular develop- 
ment occur. If in stimulated ovulatory cycles multifollicular growth was found, midluteal $\mathrm{P}$ levels were always above the average of the spontaneous ovulatory group. The maximum mean preovulatory follicle diameter in patients with spontaneous ovulatory cycles ranged between 16 and $28 \mathrm{~mm}$. The corresponding mean $E_{2}$ peak levels and mean midluteal $P$ levels belonging to each maximum mean follicle diameter were calculated. A significant correlation existed between the $\mathrm{E}_{2}$ peak level and the maximum preovulatory follicle size $(\mathrm{r}=0.38 ; \mathrm{p}<0.001)$.

There was no correlation between the follicle size and the midluteal $\mathrm{P}$ level.

Pregnancies occurred in 22 out of 210 cycles studied (15 spontaneous cycles and seven induced cycles). None occurred in a cycle in which the follicle failed to rupture. Pregnancies occurred in cycles with a wide range of mean preovulatory follicle diameters (range in the spontaneous conception cycles $18-28 \mathrm{~mm}$ ).

Figure VI. 2 shows the frequency distribution of the length of the luteal phase in the spontaneous non-conception cycles. The duration of the luteal phase in LUF cycles varied from 8 to 17 days, proportionally distributed over the different luteal phase lengths. Of the five cycles with a duration of the luteal phase of less than 11 days three showed a midluteal $P$ level below $32 \mathrm{nmol} / \mathrm{l}$. The midluteal $\mathrm{P}$ level in the remaining two cycles were 33 and $35 \mathrm{nmol} / \mathrm{l}$, respectively.

\section{Discussion}

Although in recent years much speculation has been made about the cause of LI, its pathophysiology is still unclear (DiZerega and Hodgen, 1981).

The diagnosis of LI can be suspected from the basal body temperature chart, and can be confirmed by endometrial biopsy and/or serum P levels (Jones, 1976; Andrews, 1979).

Most authors believe that LI is a disorder of the ovulatory cycle. Infertility is usually explained either by the inability of the embryo to implant in the insufficiently prepared endometrium, or by the inability of the corpus luteum to maintain the pregnancy. Coutts and coworkers (1982) found retained ovarian cysts and were the first to indicate that the deficient luteal phase also may represent an anovulatory cycle. In the current study we found a high incidence of unruptured follicles in cycles with a midluteal $P$ level below $32 \mathrm{nmol} / \mathrm{l}$. Entrapment of the oocyte in the unruptured follicle offers an additional explanation for the failure to conceive in patients with an LI.

The overall percentage of LUF cycles in this study (14.3\%) was higher than that $(6.6 \%)$ in the average infertility population (Hamilton et al., 1985). This is because midluteal $P$ levels were determined in a larger proportion of patients with LUF cycles compared to patients with ovulatory cycles and because the referral function of our fertility clinic is still growing. By extrapolation the real incidence of LUF 
cycles in an average infertility population can be calculated to be as high as $50 \%$ if the midluteal $P$ level is below $32 \mathrm{nmol} / 1$ and as low as $4 \%$ if the midluteal $P$ level is above $32 \mathrm{nmol} / \mathrm{l}$.

Disagreement exists about the value of a single $\mathbb{P}^{\prime}$ measurement in diagnosing $L I$. Some authors consider it as a reliable method (Hull et all, 1982; Shepard and Senturia, 1977), whereas others (Rosenberg, 1980) have warned against its use, because of the considerable diurnal P fluctuations. To overcome this problem, the collection of more blood samples and even the use of a progesterone index (PI) have been advocated (Coutts et al., 1982; Abraham et al., 1974). Our finding of LUF cycles only in the lower range of $\mathrm{P}$ values (Figure VI.1) stresses the clinical importance of well-timed single $P$ determinations. Ultrasound is therefore helpful in screening patients with LI.

In ovulatory cycles no relation existed between the midluteal $P$ level and the maximum mean preovulatory follicle size.

In spontaneous cycles with a luteal phase length of less than 11 days the midluteal $P$ level was always low $(<36 \mathrm{nmol} / \mathrm{l})$. A longer duration of the luteal phase did not rule out LI. The length of the luteal phase in LUF cycles did not significantly differ from that in ovulatory cycles.

Leyendecker (1979) postulated that LI, oligomenorrhoea, anovulation and amenorrhoea are different clinical manifestations of ovarian dysfunction, based on the same pathophysiological entity, namely a gradual decrease in hypothalamic LHRH secretion. The different clinical manifestations form a continuum. We hypothesize that at one end of this continuum hypogonadotropic anovulation can be found. Subsequently, a gradual change can be found from LI with a short luteal phase, LI with a normal duration of the luteal phase towards the ovulatory cycle and eventually (induced) polyovulation. Ovulation induction moves the hormonal status of an anovulatory patient in the direction of the (poly)ovulatory side. We believe that LI must be divided into anovulatory and ovulatory forms, and that both form part of the continuum. LUF cycles can occur both in spontaneous and in induced cycles. In cycles with a low midluteal $P$ level a high incidence of ovulatory disturbances may be expected. A P level above $32 \mathrm{nmol} / 1$, however, does not exclude ovulatory disturbances. Here, diagnostic ultrasound offers additional information above that of a serum $\mathrm{P}$ alone. Early embryonic loss and insufficient preparation of the endometrium are not the only explanations for infertility in LI patients. Entrapment of the oocyte in the unruptured follicle has to be regarded as an important cause of infertility in these patients. 


\section{References}

Abratham, G.E., Maroulis ${ }_{\mathrm{j}}$ G.M., Marshall, J.R.: Evaluation of ovulation and corpus luteum function using measurements of plasma progeterterone.

Obstet Gynecol $44: 522,1974$

Andrews, W.C.: Litteal phase defects.

Fertil Steril 32:501, 1979

Baumann, J.E.: Bassal body temperature: unreliable method of ovulation detection.

Fertil Steril $36: 729,1981$

Coutts, J.R.T., Adam, A.H., Fleming, R.: The deficient luteal phase may represent an anovulatory cycle.

Clin Endocrinol 17:389, 1982

Dizerega, G.S., Hodgen, G.D.: Luteal phase dysfunction infertility: a sequel to aberrant folliculogenesis.

Fertil steril $35: 489,1981$

Downs, K.A., Gibson, M.: Basal body temperature graph and the luteal phase defect.

Fertil Steril 40:466, 1983

Hamilton, C.J.C.M., Wetzels, L.C.G., Evers, J.L.H., Hoogiand, H.J., Muijtjens, A., de Haan, J.: Follicle growth curves and hormonal patterns in patients with the luteinized unruptured follicle syndrome. Fertil Steril $43: 541,1985$

Hull "M.G.R., Savage, P.E., Bromham, D.R., Ismail, A.A.A., Morris, A.F.: The value of a single serum progesterone measurement in the midluteal phase as a criterion of a potentially fertile cycle ("ovulation') derived from treated and untreated conception cycles.

Fertil Steril 37:355, 1982

Israel, R., Mishell, D.R., Stone, C., Thorneycroft, I.H., Moyer, D.L.: Single luteal phase serum progesterone assay as an indicator of ovulation.

Am J Obstet Gynecol 112:1043, 1972

Jones, G.S., Delfs, E.: Endocrine patterns in term pregnancies following abortion.

I $\mathrm{A} M \mathrm{~A} \mathrm{146:1212,1951}$

Jones, G.S.: "The luteal phase defect.

Fertil Steril $27: 3 \$ 1,1976$

Kletzky, O.A., Nakamura, R.M., Thorneycroft, I.H., Mishell, D.R.: Log normal distribution of gonadotropins and ovarian steroid values in the normal menstrual cycle.

Am J Obstet Gynecol $\mathbb{2 1} 1: 688,1975$

Koninckx, P.R., Heyns, W.J., Corveleyn, P.A.., Brosens" I.A.: Delayed onset of luteinization as a cause of infertility.

Fertil Steril 29:266, 1978

Lenton, E.A., Landgren, B-M.: The normal menstrual cycle.

In: Clinical Reproductive Endocrinology. Ed. Shearman, R.P., Edinburgh: Churchill Livingstone, pp. $81-107,1985$ 
Leyendecker, G.: The pathophysiology of typothalamic owarian falure: diagnostic and therapeutical considerations.

Eur J Obstet Gynecol Reprod Biol 9:175, 1979

Radwanska, E., Swyer, G.I.M.: Plasma progesterone estimation in infertile women and in women under treatment with clomiphene and chorionic gonadotropin.

J Obstet Gynaecol Br Commonw 81:107, 1974

Rosenberg, S.M.: Inappropriateness of single mid-luteal progesterone for the diagnosis of corpus luteum defeet (Letter).

Obstet Gynecol $56: 267,1980$

Sakamoto, C., Nakano, H.: The echogenic endometrium and alterations during menstrual cycle.

Int J Gynaec Obstet 20:255, 1982

Shepard, M.K., Senturia, Y.P.: Comparison of serum progesterone and endometrial biopsy for confirmation of ovulation and evaluation of luteal function.

Fertil Steril 28:541, 1977

Wetzels, L.C.G., Hoogland, H.J., de Haan, J.: Basal body temperature as a method of ovulation detection: comparison with ultrasonographical findings.

Gynecol Obstet Invest 13:235, 1982

Wetzels, L.C.G., Hoogland, H.J.: Relation between ultrasonographic evidence of ovulation and hormonal parameters: luteinizing hormone surge and initial progesterone rise.

Fertil Steril $37: 336,1982$ 



\section{General discussion}

In order to obtain the optimum level of patient care and to decrease the cost to benefit ratio, every diagnostic tool should be evaluated critically. With regard to the management of infertile patients one should always keep in mind, that the majority of couples who apply for medical care, will achieve pregnancy without therapy. Diagnostic procedures should be short, reliable, cost effective, and focuss on the detection of couples who really need medical treatment or, on the other hand, who belong to the group that can safely be advised to wait for a spontaneous pregnancy to occur.

Although, in theory, a fertility investigation should evaluate all conditions necessary to normal fertilization and implantation, in reality only some of these factors can be examined. History taking and physical examination of both partners can be helpful to put the fertility investigation on the right track. Tests and laboratory investigations have been developed to delineate the diagnosis further.

The standard fertility investigation can be divided into two parts. The basal screening part of which ovulation detection, semen analysis and the PC test are the principal constituents, and a second part in which tubal patency and intrapelvic disorders are investigated.

In the traditional fertility screening, ovulation is usually detected by means of the BBT. The PC test is timed according to the menstrual history, while examination of the cervical mucus gives additional information about the correct timing of the preovulatory period. Both methods, however, are inaccurate and lead to inappropriate timing of fertility tests. This causes an increased number of false-negative test results; frequent repetition of the tests ensues, which diminishes its costeffectiveness.

An important new development in the fertility screening has been the introduction of diagnostic ultrasound. In earlier studies the usefulness of ultrasound in detection of ovulation has been demonstrated. It is more reliable than the more frequently used BBT chart.

A practical problem, however, is that experienced personel and appropriate equipment must be available on a continuity basis. Serial ultrasound scans of the same patient must be performed by the same investigator to get the most reliable results. The application of ultrasound in the fertility clinic, thusfar described in literature, 
has mainly been focussed on monitoring of ovulation induction and timing of artificial insemination. Furthermore, ultrasound has acquired an important role in the localization and aspiration of follicles in in-vitro fertilization programs. Ultrasound has also been used in case of unexplained infertillity to detect ovulation disturbances. Most applications, however, concern indications in a rather advanced stage of the fertility investigation or treatment.

Diagnostic ultrasound is valuable in the fertility clinic because it anticipates upon the ensuing ovulation and because it is a noninvasive technique. This latter feature allows the procedure to be repeated at suitable intervals and thus to determine the moment of ovulation with great precision.

If a dominant follicle larger than $14 \mathrm{~mm}$ is observed it is very likely that ovulation will take place within the next 7 days. When diameters increase the time window in which ovulation is likely to occur, becomes smaller. The ovulation predictive value of ultrasound increases. Most other methods of ovulation detection are either less reliable as a method of ovulation prediction or too invasive for application in the standard fertility screening.

The aim of this thesis was to investigate new applications of ultrasound in the fertility clinic. We demonstrated that diagnostic ultrasound can be useful in the basal screening part of a fertility investigation. By incorporating ultrasound in the first stage of the fertility investigation, as described in chapter II and applying the prediction rule as described in chapter III, the standard fertility screening has changed considerably in our clinic. The basic fertility screening can be performed during one single menstrual cycle, irrespective of the cycle length, whereas the results are much more reliable. If ultrasound is to be incorporated into the standard fertility screening, the work-up could be as follows:

In a regular menstrual cycle of 28 days a first ultrasound scan is performed between days 10 and 12 of the cycle. Depending on the length of the previous menstrual cycles, ultrasound scans can be planned earlier or later. If the actual size of the displayed follicle is smaller than $14 \mathrm{~mm}$, the ultrasound examination should be repeated 3 days later. If, on the other hand, a dominant follicle of more than $14 \mathrm{~mm}$ is visible, the fertile period has started and the couple is advised to have intercourse every other day. Depending on the exact follicular size and based on the prediction curve (chapter III) a PC test is performed. The ultrasound scan should be repeated every other day until evidence of ovulation will have been obtained. The PC test can be performed immediately after each scan and can be repeated in the same frequency as the scans until the follicle has ruptured.

Ultrasound timing will increase the probability that optimal cervical mucus characteristics will be found. This releases the couple from the obligation to have intercourse at fixed intervals before the PC test, which often is rather stressful. The advise to have intercourse every other day during the fertile period will suffice. A maximum of $3 \mathrm{PC}$ tests will have to be performed in order to obtain at least one well-timed test. In most cases one single test will suffice. The finding of only a few propulsive spermatozoa per HPF in a patient determines her prognosis to be poorer 
compared to patients in whom an abundant amount of spermatozoa per HPF is found. It is essential to continue ultrasound investigations and the PC tests every other day until ovulation has taken place, even if a positive test has been found already, to obtain the best possible test result. Ultrasound supplies substantial evidence of the follicle rupture to have occurred. It also allows precise timing (i.e. relative to the exact moment of ovulation) of single or serial $\mathrm{P}$ determinations in the luteal phase. This will enable evaluation of luteal function in a standardized way. If the postcoital test is negative, despite the presence of normal appearing cervical mucus, the mucus is stored at $4^{\circ} \mathrm{C}$ to perform a sperm penetration test or immunologic examinations later on, when a specimen of semen is brought for semen analysis.

If no abnormalities are found a hysterosalpingography can be performed after the subsequent menstrual period. An additional advantage found in the present study was the pregnancy rate to be higher in the cycles monitored by ultrasound as compared to the pregnancy rate in traditionally screened cycles $(18.3 \%$ vs. $6 \%)$. This stresses the important role of adequate timing of intercourse in the treatment of subfertile couples.

If abnormalities are found or if examinations need to be repeated, the same rigid protocol should be followed. Inappropriate timing will give unreliable results and several months will pass without progress in the fertility screening being made. Monitoring ovulation by diagnostic ultrasound can also be of use in artificial insemination. Because assessment of the fertile period is a prerequisite to the success of this procedure, a single ultrasound scan will be sufficient, if at least a dominant follicle larger than $14 \mathrm{~mm}$ is found. After previous screening confirmation of the ovulation during insemination cycles is not obligatory. The advantage of ultrasound is that in the majority of patients inseminations can be timed appropriately with a single ultrasound examination, and consequently that the number of inseminations can be limited.

More investigation is needed to evaluate the usefulness of hCG in timing artificial inseminations. In view of the considerable variation in maximal mean preovulatory follicle diameter in conception cycles (Figure II.3) an optimal follicle size to give the hCG injection does not exist. Perhaps investigation of both the follicle size and the ultrasonographic aspect of the endometrium can help to indiwidualize the treatment. Both the present and earlier studies indicate that, in general, the intraindividual variation in follicle growth curves is smaller than the interindividual variation. Larger series, however, will be necessary to substantiate the fact that ovulation prediction can be more reliable if it is based on findings from earlier cycles of the same patient. The fact that a single measurement suffices, once again emphasizes the importance of adequate experience in recognizing the ultrasound pictures. If there is doubt about the identity of a translucent structure within one of the ovaries, a second scan can be helpful to observe the dynamic changes of this structure.

Another major advantage of ultrasonographic follicle measurement in screening infertility patients is the possibility to detect disturbances in follicle growth and ovula- 
tion. With serial ultrasound scans we were able to detect follicles, which did not rupture following the $\mathrm{LH}$ peak, and which persisted during the luteal phase. Their characteristic growth pattern was never observed in conception cycles. Unruptured follicles must, of course, be differentiated from cystic corpora lutea. In general, after ovulation a follicle collapses or decreases in size, before the corpus luteum becomes visible as a translucent structure. Repeated ultrasound scans are therefore necessary to differentiate between the two. Ultrasound is less invasive than puncture of the pouch of Douglas or laparoscopic aspiration of the peritoneal fluid to obtain evidence of the LUF syndrome.. In a patient known to have LUF syndrome in one cycle, the recurrence rate can be examined by means of ultrasound. To demonstrate recurrence of a LUF two ultrasound investigations will be sufficient: one to calculate the expected moment of ovulation, and the second to confirm the failure of the follicle to rupture. The simultaneous finding of a 'luteal' endometrium will substantiate the diagnosis. Also the effect of treatment of the LUF syndrome can be assessed.

As discussed in chapter IV there are 3 different groups of patients with a failure of the follicle to rupture:

1. Patients, who only rarely show this phenomenon. It is most probably a random finding and the disturbance will hardly influence the prognosis of these patients.

2. Patients with induction of ovulation. The recurrence rate in these patients is higher. The failure of the follicle to rupture may be a reasonable explanation for the discrepancy between 'ovulation' rate and pregnancy rate in patients treated with ovulation induction.

3. Patients with a history of previous PID. Especially if an LUF does repeatedly occur in a patient with a spontaneous menstrual cycle, this should raise suspicion of sequelae of a previous PID. Laparoscopy may be indicated to reveal abnormalities in the pelvis.

The occurrence of LUF in patients with a previous PID suggests the existence of a local cause for the ovulation disturbance. Although the pathophysiology of the LUF syndrome is still unclear, we believe that both central and local disorders may cause the owulation disturbance. Ultrasound may be helpful to further delineate the pathophysiology of this ovulation disturbance: to standardize the time of follicle puncture to investigate the levels of proteolytic enzymes in the follicular fluid or to investigate follicular wall characteristics. Ultrasound may also be of use in evaluating methods of treatment. For instance the value of microsurgery or antibiotics in patients with a previous PID and the value of administration of hCG in patients with a central cause of the LUF syndrome may be subject to further investigations. Finally the observation of low midluteal $P$ levels in cycles with a failure of the follicle to rupture sheds new light upon the phenomenon of LI. Half of the cycles with a low midluteal $P$ level represent a LUF cycle. In cycles with normal $P$ levels the incidence of LUF is extremely low. Entrapment of the oocyte in the unruptured follicle has to be regarded as an important cause of infertility in patients with LI. Ultrasound enables standardization of midluteal $P$ determinations. Ultrasound in- 
vestigation of the endometrium will, perhaps, enlarge our possibilities to diagnose endocrine disturbances of the luteal phase.

Further investigations should be focussed on the study of the relation between endocrine changes and disturbances of follicle growth and ovulation. This could, eventually, reduce the number of patients diagnosed to be suffering from unexplained infertility. 


\section{Summary}

The applications of ultrasound in the fertility clinic, thusfar described in literature, concern mainly: 1) ovulation induction, 2) the detection and aspiration of follicles in IVF programs, 3) the detection of ovulation disturbances in patients with unexplained infertility, and 4) the timing of artificial inseminations. Ultrasound is usually applied in an advanced stage of the fertility investigation or treatment.

The aim of this thesis was to investigate new applications of ultrasound in the fertility clinic.

As introduction a review of the literature is given in chapter I, concerning the physiology of follicle growth and ovulation. Currently used methods of ovulation detection and prediction are described, and the role of ultrasound in particular is reviewed.

In chapter II the application of ultrasound as the first step of the fertility screening is studied. A comparison is made between the traditional fertility workup and the fertility screening guided by ultrasound. Fifty women from newly registered infertile couples were screened in a traditional way. The postcoital test failed to show any prognostic value. Optimal timing of the postcoital test by ultrasound, on the other hand, in another group of 54 patients, turned it into a highly significant prognostic test. The duration of the basal fertility screening period could be reduced. Also the administration of clomiphene-citrate and estrogens, to treat putative anovulation or poor cervical mucus characteristics, could be reduced. It is concluded, that ultrasound increases the efficacy and the reliability of the fertility screening.

In chapter III the ovulation predictive value of ultrasound is studied in a group of 158 spontaneously ovulating women. A prediction rule, correlating the follicular diameter with the time interval to ovulation, is constructed based on the data of the first 100 women. Only one single randomly selected measurement per patient was used. For, it could be demonstrated that serial follicular measurements, to calculate the slope of the follicle growth curve, did not enhance the ovulation predictive value of ultrasound. The prediction interval, i.e. the calculated window of time in which ovulation will take place, decreases with increasing follicular size to a minimum of $21 / 2$ days. Although this predictive value is only limited, it is an improvement, compared to the ovulation predictive value based on the menstrual history. It is sufficiently useful to time procedures like postcoital tests and artificial inseminations. Validation of the prediction rule in another group of 58 patients demonstrated its adequacy.

In chapter IV the results are presented of a prospective study in 270 infertility patients, concerning the incidence of the "luteinized unruptured follicle (LUF) syndrome". This syndrome is characterized by a failure of the follicle to rupture despite signs of luteinization. The disturbance can be diagnosed by means of laparoscopy. The absence of an ovulation stigma and low steroid hormone concentrations of the peritoneal fluid in the early luteal phase substantiate the diagnosis of the syndrome. 
Using diagnostic ultrasound we could find a failure of the follicle to rupture, despite signs of luteinization, in $10 \%$ of infertility patients. The ovulation disturbance was found in $6.6 \%$ of all 600 cycles studied. Follicle growth curves and hormonal parameters of 20 LUF patients are described and compared to those of 45 normally ovulating women. In LUF cycles a characteristic accelerated follicle growth pattern could be demonstrated following the LH peak. Both the serum LH peak levels and the midluteal serum progesterone levels were significantly lower in LUF cycles as compared to control cycles. A failure of the follicle to rupture seems to occur in 3 groups of patients: 1) patients with unexplained infertility, 2) patients treated with clomiphene-citrate or LHRH, and 3) patients with a previous pelvic inflammatory disease. This suggest that different mechanisms can be held responsible for the ovulation disturbance.

Based on the finding of ovulation disturbances in patients with a previous pelvic inflammatory disease, we extended the study to a group of 25 patients, in whom sequelae of a previous pelvic infection had been found at laparoscopy. The results are discussed in chapter $\mathrm{V}$. Thirteen out of 25 women exhibited a failure of the follicle to rupture in at least one cycle. A mechanical cause could only be found in a minority of patients. Microsurgery did not seem to reduce the incidence of the ovulation disturbance. Perhaps a chronic oophoritis plays a role in the pathophysiology of this ovulation disturbance. If a failure of the follicle to rupture is found in a woman with a previous pelvic infection, the recurrence rate of the ovulation disturbance is high. This ovulation disorder seems to be an important and neglected cause of failure of fertility microsurgery.

In chapter IV a relation was found between the accurrence of ovulation disturbances and low midluteal serum progesterone levels. To investigate the importance of ovulation disturbances in women with luteal insufficiency, the data of 210 cycles in 170 patients were studied. Both spontaneous and induced cycles were included. The results are discussed in chapter VI. In cycles with a low midluteal serum progesterone level (below $32 \mathrm{nmol} / \mathrm{l}$ ) the incidence of LUF cycles could be calculated to be as high as $50 \%$. If the midluteal progesterone level was normal (above $32 \mathrm{nmol} / 1$ ) the incidence was only $4 \%$. The high incidence of ovulation disturbances in cycles with low serum progesterone levels sheds new light upon the pathophysiology of luteal insufficiency. The failure of the follicle to rupture has to be considered as an important cause of infertility in patients with luteal insufficiency.

In chapter VII the results of the previous chapters are integrated. A brief outline is given of the basal screening part of the fertility investigation if ultrasound is to be incorporated into the work-up. Some suggestions for further investigation are given. 
De tot nu toe in de literatuur beschrewen toepassingen van echoscopische follikelmetingen hebben vooral betrekking op 1) ovulatie-inductie, 2) het detecteren en aspireren van follikels in het kader van de IVF, 3) het opsporen van ovulatiestoornissen in geval van onbegrepen infertiliteit en 4) het bepalen van het optimale moment van kunstmatige inseminaties. Het betreft toepassingen in een relatief ver gevorderd stadium van het fertiliteitsonderzoek of de behandeling.

Doel van dit proefschrift was enkele nieuwe toepassingen wan echoscopie op het gebied van het fertiliteitsonderzoek te bestuderen.

Ter introductie wordt in hoofdstuk I een literatuuroverzicht gegeven betreffende de fysiologie van de follikelgroei en de eisprong. De meest courante methoden van ovulatiedetectie en predictie worden besproken. Meer in het bijzonder wordt ingegaan op de rol die de echoscopie hierbij speelt.

In hoofdstuk II wordt onderzocht of het toepassen van echoscopie in de eerste fase van het fertiliteitsonderzoek van voordeel kan zijn. Het klassieke fertiliteitsonderzoek wordt vergeleken met het onderzoek uitgevoerd op geleide van echoscopische follikelmeting. Bij 50 op klassieke wijze gescreende nieuwe infertiliteitspatiënten blijkt de postcoitum test geen prognostische waarde van betekenis te hebben. Indien daarentegen de test bij 54 andere patiënten met behulp van echoscopie zeer dicht op het ovulatiemoment wordt uitgevoerd, blijkt de test wel een duidelijk voorspellende waarde te bezitten. Het basale fertiliteitsonderzoek kan met behulp van echoscopie in een korter tijdsbestek worden afgerond. Het gebruik van clomipheen en oestrogenen wegens vermeende anovulatie of slechte cervixslijmkwaliteit kan drastisch worden teruggebracht.

Geconcludeerd kan worden dat het fertiliteitsonderzoek door gebruik te maken van echoscopie aan efficiëntie en betrouwbaarheid wint.

In hoofdstuk III wordt de ovulatie-voorspellende waarde van echoscopie nader bestudeerd bij een groep van 158 spontaan ovulerende vrouwen. Op basis van de gegevens van de eerste 100 vrouwen wordt een predictie-regel opgesteld, die de follikeldiameter correleert met het tijdsinterval tot de ovulatie. Van elke vrouw wordt slechts één at random gekozen meting voor de predictieregel gebruikt. Aangetoond wordt namelijk, dat het frequenter meten van de follikelgrootte met het oogmerk de richtingscoëfficient van de follikelgroeicurve te berekenen het predictieve vermogen van de echoscopie niet verhoogt. Het predictie-interval waarbinnen de ovulatie zal plaatsvinden neemt bij een toenemende follikeldiameter af tot een minimum van $2 / 2$ dag. Hoewel dit nog niet erg nauwkeurig is betekent dit in ieder geval een verbetering ten opzichte van de voorspelling van het ovulatiemoment op basis van de cyclus anamnese. Voor procedures als de postcoitum test of kunstmatige inseminaties is de methode in ieder geval bruikbaar. De predictieregel werd in een groep van 58 andere vrouwen getoetst en valide bevonden.

Hoofdstuk IV bespreekt de resultaten van prospectief onderzoek bij 270 patiënten 
naar het voorkomen van het "luteinized unruptured follicle syndrome", kortweg LUF syndroom genoemd. Bij dit syndroom blijft de follikelruptuar achterwege, ondanks tekenen van luteïnisatie zoals het stijgen van de basale lichaamstemperatuur en het vinden van verhoogde progesteron-spiegels in de tweede cyclushelft. De diagnose kan gesteld worden met behulp van laparoscopie. Het ontbreken van een ovulatiestigma en het vinden van lage steroïdhormoon-concentraties in peritoneumvloeistof tijdens de vroeg-luteale fase wijzen op het bestaan van het syndroom. In het hier beschreven echoscopisch onderzoek blijkt dat uitblijven van de follikelruptuur ondanks tekenen van luteïnisatie voorkomt bij $10 \%$ van de infertiliteitspatiënten. Van de in totaal 600 onderzochte cycli vertoonden $6.6 \%$ de afwijking. De follikelgroeicurve en de hormonale parameters van 20 LUF patiënten worden beschreven en vergeleken met die van 45 normaal ovulerende vrouwen. In LUF cycli treedt na de LH piek een karakteristieke follikelgroeispurt op en blijft de follikelruptuur uit. Zowel de serum LH piek als de midluteale serum progesteron spiegel zijn in LUF cycli gemiddeld significant lager dan in controle cycli. Niet rupturerende follikels blijken in 3 groepen patiënten voor te komen, namelijk 1) patiënten met onbegrepen infertiliteit, 2) patiënten die behandeld worden met clomipheen of LHRH en 3) patiënten die een ontsteking in het kleine bekken in de anamnese hebben. Dit wijst erop dat verschillende oorzaken aan de ovulatiestoornis ten grondslag kunnen liggen.

Voortbouwend op de bevinding, dat ovulatiestoornisen kunnen voorkomen bij patiënten die een ontsteking in het kleine bekken gehad hebben, werd het onderzoek in deze laatste groep patiënten uitgebreid. In totaal 25 patienten, bij wie bij laparoscopisch onderzoek restletsels van een vroeger doorgemaakt infect in het kleine bekken waren aangetoond, maakten deel uit van deze vervolgstudie. De resultaten worden besproken in hoofdstuk $\mathrm{V}$. Bij 13 van de 25 vrouwen werd tenminste in één cyclus een ovulatiestoornis opgemerkt. Een mechanische oorzaak voor de ovulatiestoornis kon slechts bij een beperkt aantal vrouwen worden gevonden. Microchirurgie verminderde het voorkomen van ovulatiestoornissen niet. Mogelijk speelt een chronische oöphoritis een rol in de pathogenese. Wordt bij een vrouw die in het verleden een pelviene infectie heeft doorgemaakt een ovulatiestoornis gevonden dan is de herhalingskans voor een ovulatiestoornis groot. Stoornissen in het ovulatiemechanisme blijken derhalve een belangrijke, tot nu toe verontachtzaamde oorzaak van het uitblijven van zwangerschap na fertiliteitsbevorderende ingrepen te zijn. In hoofdstuk IV was reeds een verband gevonden tussen het voorkomen van ovulatiestoornissen en lage midluteale progesteron spiegels. Om het aandeel van ovulatiestoornissen in de totale groep van luteale insufficiëntie te bestuderen, werden de gegevens van alle vrouwen onderzocht van wie voldoende progesteronwaarden voorhanden waren om de luteale fase te kunnen beoordelen. Het betrof $210 \mathrm{cycli}$ van 170 patiënten. Zowel spontane als geïnduceerde cycli werden onderzocht. De resultaten worden besproken in hoofdstuk VI. In cycli met een lage midluteale serum progesteron-spiegel $(<32 \mathrm{nmol} / \mathrm{l})$ is de incidentie van ovulatiestoornissen $50 \%$. In cycli met een normaal serum progesteron-gehalte $(>32 \mathrm{nmol} / \mathrm{l})$ is de incidentie 
slechts $4 \%$. Dit hoge percentage ovulatiestoornissen in cycli met een laag serum progesteron-gehalte werpt nieuw licht op de pathofysiologie van de luteale insufficiëntie. Het niet vrijkomen van de eicel uit de follikel moet derhalve als een belangrijke oorzaak van infertiliteit bij deze patiënten worden gezien.

In hoofdstuk VII worden tenslotte de resultaten uit de voorgaande hoofdstukken geïntegreerd. Tevens wordt geschetst hoe het basale fertiliteitsonderzoek eruit kan zien, wanneer gebruik gemaakt wordt van echoscopische follikelmeting en ovulatiedetectie. Enige aanzetten tot verder onderzoek worden gegeven. 


\section{Curriculum Vitae}

22.06.1953 Geboren te Nijmegen

1972

Eindexamen gymnasium- $\beta$ aan het Bisschoppelijk College te Roermond

1979

Artsexamen aan de Katholieke Universiteit te Leuven, België

1979

Arts-assistent Obstetrie/Gynaecologie in het De Weverziekenhuis te Heerlen

(Opleider: Dr L.A. Schellekens)

1980

Arts-assistent Obstetrie/Gynaecologie in de Vroedvrouwenschool te Heerlen

(Opleider: Dr R. Omers)

1980-1984 A-opleiding Obstetrie/Gynaecologie in het Ziekenhuis

St. Annadal te Maastricht

(Opleider: Prof. Dr J. de Haan)

1984-1985 B-opleiding Obstetrie/Gynaecologie in het St. Laurentiusziekenhuis te Roermond (Opleider: Dr L.C.G. Wetzels)

15.06.1985 Inschrijving specialistenregister

vanaf 1985 Als staflid verbonden aan de Capaciteitsgroep Obstetrie/Gynaecologie van het Academisch Ziekenhuis te Maastricht 